MARCO ANTONIO LOSCHIAVO LEME DE BARROS

TRIBUNAIS, COMPLEXIDADE E DECISÃO: O ARGUMENTO CONSEQUENCIALISTA NO DIREITO BRASILEIRO

Tese de Doutorado

Orientador: Professor Titular Dr. Celso Fernandes Campilongo

UNIVERSIDADE DE SÃO PAULO

FACULDADE DE DIREITO

SÃO PAULO - SP

2018 

MARCO ANTONIO LOSCHIAVO LEME DE BARROS

\section{TRIBUNAIS, COMPLEXIDADE E DECISÃO: O ARGUMENTO CONSEQUENCIALISTA NO DIREITO BRASILEIRO}

Tese apresentada à Banca Examinadora do Programa de Pós-graduação em Direito da Faculdade de Direito da Universidade de São Paulo, como exigência parcial para obtenção do título de Doutor em Direito, na área de concentração Filosofia e Teoria Geral do Direito, sob a orientação do Professor Titular Dr. Celso Fernandes Campilongo.

UNIVERSIDADE DE SÃO PAULO

FACULDADE DE DIREITO

SÃO PAULO - SP 
Serviço de Biblioteca e Documentação Faculdade de Direito da Universidade de São Paulo

BARROS, Marco Antonio Loschiavo Leme de. Tribunais, complexidade e decisão: o argumento consequencialista no direito brasileiro / Marco Antonio Loschiavo Leme de

BARROS; orientador Celso Fernandes Campilongo -- São Paulo, 2018. 382 f.

Tese (Doutorado - Programa de Pós-Graduação em Filosofia do Direito e Teoria Geral do Direito) Faculdade de Direito, Universidade de São Paulo, 2018.

1. Sociologia do Direito. 2. Direito e Sociedade. 3. Teoria dos Sistemas 4. Argumento Consequencialista.

I. Campilongo, Celso Fernandes, orient. II. Título. 


\section{FOLHA DE APROVAÇÃO}

Nome: Marco Antonio Loschiavo Leme de Barros

Título: TRIBUNAIS, COMPLEXIDADE E DECISÃO: O ARGUMENTO CONSEQUENCIALISTA NO DIREITO BRASILEIRO

Tese apresentada à Banca Examinadora do Programa de Pós-graduação em Direito da Faculdade de Direito da Universidade de São Paulo, como exigência parcial para obtenção do título de Doutor em Direito, na área de concentração Filosofia e Teoria Geral do Direito, sob a orientação do Professor Titular Dr. Celso Fernandes Campilongo.

Aprovada em:

\section{BANCA EXAMINADORA}

Prof. Tit. Dr. Celso Fernandes Campilongo

Julgamento:

Prof. Dr.

Julgamento:

Prof. Dr.

Julgamento:

Prof. Dr.

Julgamento:

Prof. Dr.

Julgamento:

Prof. Dr.

Julgamento:
Instituição: Universidade de São Paulo Assinatura:

Instituição:

Assinatura:

Instituição:

Assinatura:

Instituição:

Assinatura:

Instituição:

Assinatura:

Instituição:

Assinatura: 
Aos meus pais, Maria Cecília e Mario Thadeu, com alegria; à Adriana, com carinho. 


\section{AGRADECIMENTOS}

O desenvolvimento de uma pesquisa e a elaboração de uma tese fazem parte de uma jornada investigativa. Nesta caminhada, tive a oportunidade de encontrar, discutir e aprender com diferentes professores e pesquisadores, e deparei-me com diversas situações. Sem estas distintas comunicações - dotadas de elevada contingência -, nenhum conhecimento seria possível.

Muitas das ideias aqui registradas fazem parte destas comunicações estabelecidas nos últimos três anos e refletidas pelo pesquisador. Cabe, então, reconhecer e agradecer aos principais interlocutores, sejam dos planos acadêmico e institucional, sejam do âmbito familiar.

Ao professor Celso Campilongo, principal interlocutor, pela generosidade e pela orientação do presente trabalho na Universidade de São Paulo com liberdade, respeito e confiança. O seu espírito desafiador e a sua seriedade acadêmica serviram de exemplo para esta pesquisa e para o pesquisador. Suas aulas, seus livros e suas palavras tornaram-se fundamentais para minha formação acadêmica.

Ao professor Stephen Gardbaum, meu supervisor na Universidade da Califórnia, em Los Angeles, pela acolhida no exterior, que possibilitou o amadurecimento de minhas ideias e uma estrutura para a redação do texto, além da vivência em uma diferente experiência acadêmica. Agradeço-lhe, também, pelas conversas e aulas que contribuíram para a minha reflexão.

Aos professores Orlando Villas Bôas Filho e Laurindo Dias Minhotto, pelas importantes observações feitas no exame de qualificação, as quais auxiliaram no desenvolvimento posterior da pesquisa e na estruturação global da tese.

Aos professores com quem mantive contato no curso do programa de doutorado, ou mesmo em conversas e encontros fora deste âmbito, em especial durante os estágios de pesquisa em Oñati e em Los Angeles, e àqueles que me auxiliaram em algum momento da pesquisa. Registro, entre outros, Adam Czarnota; Ana Lucia Pastore; Fabiana Luci; Fernando Rister; Flávia Püschel; Gary Blasi; Joxerramon Bengoetxea; Luciana Ramos; Mark Greenberg; Maria Cecília Pinho; Rogério Arantes; Ronaldo Macedo Junior; Silvia Pimentel. 
Aos pesquisadores que conheci na universidade e em eventos científicos. Em especial, àqueles para os quais tive a oportunidade de apresentar algumas ideias preliminares nos congressos "Sociology of law on the move: perspectives from Latin America"; "XXVIII World Congress on the Philosophy of Law and Social Philosophy"; "VIII Congresso da Associação Brasileira de Pesquisadores em Sociologia do Direito"; ou no "IV Encontro Nacional de Antropologia do Direito" e no "Encontro Regional de Pesquisa Empírica em Direito".

Aos amigos e pesquisadores Andréa Martos Naccache, Caio Santiago Fernandes Santos, Fernando Bezzi, Gabriel Ferreira da Fonseca, Haroldo Pereira, Lucas Fucci Amato, Thaís Helena Smilgys, em especial pela atenta leitura e sugestões na etapa final da produção do texto. À Bruna Bassette, meu agradecimento pela ajuda com a revisão do texto.

À convivência acadêmica com professores, funcionários, pesquisadores visitantes, colegas de monitoria e participantes do programa de pós-graduação da Faculdade de Direito da Universidade de São Paulo, todos comprometidos em produzir pesquisa em direito e em fortalecer o conhecimento científico do país.

Às instituições com as quais direta ou indiretamente estabeleci uma relação neste período: Universidade de São Paulo; Universidade da Califórnia, em Los Angeles; Instituto Internacional de Sociologia Jurídica, em Oñati; Universidade Paulista - campus Pinheiros; Núcleo de Justiça e Constituição da Fundação Getulio Vargas e Pontifícia Universidade Católica de São Paulo.

À Fundação de Amparo à Pesquisa do Estado de São Paulo - FAPESP (processo 2015/05525-0), que possibilitou minha dedicação exclusiva à pesquisa. Sem sua infraestrutura administrativa e científica, não teria todas as oportunidades para pesquisar nas melhores condições possíveis no país.

À convivência familiar e à amizade de diferentes pessoas, muitas cúmplices argutas de minhas ideias e todas presentes na minha vida. Em especial, aos meus pais, Mario Thadeu e Maria Cecília - a quem dedico esta tese -, à minha querida avó Ilda, ao meu irmão e amigo Mario Filho e sua esposa, aos meus sobrinhos Rodrigo e Marcelo e, muito carinhosamente, à Adriana, inestimável companhia, que compartilha comigo de sentimentos e sonhos, formas e ideias.

Muito obrigado a todos.

E ao leitor, meu convite para que estas comunicações perdurem. Boa leitura! 
Digo, por exemplo, que, necessariamente, acontecerá uma batalha naval amanhã ou não acontecerá; em verdade, nem acontecerá necessariamente a batalha naval amanhã, nem necessariamente não acontecerá. Todavia, acontecerá ou não acontecerá necessariamente. Por conseguinte, uma vez que os discursos verdadeiros são, de uma maneira semelhante, conforme os fatos, é evidente que todos esses são de um modo tal que sucedam de uma maneira ou de outra e que os contrários possam admitir-se.

Aristóteles, Da Interpretação 9, 19a30 a 19a35 


\section{RESUMO}

BARROS, Marco Antonio Loschiavo Leme de. Tribunais, complexidade e decisão: o argumento consequencialista no direito brasileiro. 2018. $382 \mathrm{ff}$. Tese (Doutorado em Direito)

- Faculdade de Direito, Universidade de São Paulo, São Paulo, 2018.

Investiga-se nesta tese, sob inspiração da perspectiva sociológica sistêmica de Niklas Luhmann, a crescente utilização de argumentos consequencialistas no direito brasileiro. Ao longo das três últimas décadas, a quantidade de legislações que buscam concretizar os objetivos estabelecidos na Constituição de 1988 aumentou no país, bem como se observou o desenvolvimento de técnicas jurídicas para a sua consecução, dentre as quais se destaca a argumentação consequencialista a fim de analisar a pertinência entre meios e fins normativos. Paradoxalmente, constatou-se também a fragilidade dos tribunais em relação à operação destes argumentos, baseados em métodos técnico-científicos e probabilísticos estranhos ao direito. Considerando o diagnóstico de déficit operativo do Judiciário brasileiro - segundo o qual legislação e contratos não são capazes de evitar a judicialização de questões que não foram suficientemente alocadas em outras instâncias programatórias -, defende-se a hipótese de que a expansão do recurso ao argumento consequencialista em juízo pode provocar sua descaracterização operativa em razão da não observação dos limites do sistema jurídico. Pelo viés sistêmico, este argumento reflete uma nova dinâmica dos tribunais na sociedade e pode ser descrito por um modelo de observações multinível. A tese apresenta três diferentes posições de observação sobre o argumento consequencialista. Primeira, a autodescrição da teoria do direito, que gradativamente produz uma distinção semântica relativa ao consequencialismo e ao argumento consequencialista. Segunda, a autodescrição da sociedade brasileira, que como especificação do sistema social global, é dominada pela comunicação dos experts, baseada sobretudo pela forma digital e pelos desdobramentos da economização; e que pode ser refletida a partir de metacódigos como inclusão/exclusão e risco/perigo. Terceira, a autodescrição dos tribunais, que podem ser notados, simultaneamente, tanto como organizações centrais do sistema jurídico quanto como organizações periféricas, cada vez mais atuantes nos sistemas político e econômico. Sob esta perspectiva, correlaciona-se a uma pesquisa empírica referente ao comportamento decisório do Supremo Tribunal Federal a partir do marco do texto constitucional de 1988 em sede de controle concentrado de constitucionalidade de casos de direitos econômicos. As três diferentes posições de observação e a pesquisa empírica possibilitam o exame do funcionamento dos tribunais na sociedade e de como o direito brasileiro lida com questões produzidas por seu entorno, sem a perda de sua precípua função de tomada de decisões.

Palavras-chave: Sociologia do Direito; Direito e Sociedade; Teoria dos Sistemas; Argumento Consequencialista 


\begin{abstract}
BARROS, Marco Antonio Loschiavo Leme de. Courts, complexity and decision: the consequentialist reasoning in Brazilian Law. 2018. 382 ff. Thesis (PhD in Law) - Law School, University of São Paulo, São Paulo, 2018.
\end{abstract}

This thesis investigates, inspired by the systemic sociological perspective of Niklas Luhmann, the growing use of consequentialist reasoning in Brazilian law. Over the past three decades, the number of statues that have been pursuing concrete goals established in the 1988 Constitution has increased in the country, as well as the development of legal techniques for its achievement, among which the consequentialist reasoning between legal means and normative purposes. Paradoxically, there is also a weakness of the courts regarding the operation of this reasoning, which is based on technical-scientific and probabilistic methods, usually unrelated to legal systems. Considering the diagnosis of the operative deficit of the Brazilian Judiciary - in which statues and contracts are not able to avoid access in court of issues that were not sufficiently allocated in other programmatic instances -, I argue the hypothesis that the increase of the consequentialist legal reasoning in court may lead to a de-characterization of this type of reasoning by not observing the operative limits of the legal system. In the systemic perspective, consequentialism reflects a new dynamic of the courts and I present three different positions of observation (multilevel observation) about the consequentialist reasoning. First, the self-description of legal theory, which gradually produces a new semantic based on legal consequentialist reasoning. Second, the self-description of Brazilian society, which as an environment of Brazilian law is increasingly characterized as part of world society that is based on the communication of experts, the digital communication and processes of economization, that unfolds from metacodes such as inclusion/exclusion and risk/ danger. Third, the self-description of the courts, which can be observed simultaneously as center of the legal system and as peripheral organizations, increasingly active in the political and economic systems. In this last observation, I discuss empirical data on the decision-making behavior of the Brazilian Federal Supreme Court since the promulgation of the 1988 constitutional text, in cases regarding concentrated judicial review of economic rights. These three different positions of observation and empirical data allow us to examine the functioning of courts in society and how Brazilian law deals with issues produced by its surroundings, without losing its main functionality of legal decision-making.

Keywords: Sociology of Law; Law and Society; Systems Theory; Consequentialist Reasoning 


\section{RÉSUMÉ}

BARROS, Marco Antonio Loschiavo Leme de. Tribunaux, complexité et décision: l'argumentation conséquentialiste en droit brésilien. 2018. $382 \mathrm{ff}$. Thèse (Doctorat en Droit) - Faculté de Droit, Université de São Paulo, São Paulo, 2018.

Cette thèse étudie, inspirée par la perspective sociologique systémique de Niklas Luhmann, l'utilisation croissante des arguments conséquentialistes dans le droit brésilien. Au cours des trois dernières décennies, le nombre de législations qui ont poursuivi des objectifs concrets établis dans la Constitution de 1988 a augmenté dans le pays, ainsi que le développement de techniques juridiques pour sa réalisation, parmi lesquelles se détache l'argumentation conséquentialiste afin d'analyser la pertinence entre moyens juridiques et fins normatifs. Paradoxalement, il est également perceptible l'existence d'une faiblesse des tribunaux concernant le fonctionnement de ces arguments, qui reposent sur des méthodes technicoscientifiques et probabilistes sans rapport avec la loi. Compte tenu du diagnostic du déficit opérationnel de la magistrature brésilienne - selon lequel la législation et les contrats ne sont pas en mesure d'éviter l'accès aux tribunaux de questions qui n'ont pas été suffisamment réparties dans d'autres instances programmatiques -, cette thèse défend l'hypothèse selon laquelle l'augmentation du recours à l'argument conséquentialiste en justice peut conduire à une détournement du sens de ce type d'argumentation en ne respectant pas les limites opérationnelles du système juridique. Par le biais systémique, le conséquentialisme reflète une nouvelle dynamique des tribunaux et cette thèse présente trois positions différentes d'observation (observation multi-niveaux) sur l'argument conséquentialiste. Premièrement, l'auto-description de la théorie du droit, qui produit progressivement une sémantique substantielle par rapport à l'opération en fonction des conséquences par la loi. Deuxièmement, l'auto-description de la société brésilienne qui, en tant qu'ambiance du droit brésilien, se caractérise de plus en plus par une société d'experts basée sur la communication numérique et se déroule à partir de catégories telles que l'inclusion/exclusion et les risques/dangers. Troisièmement, l'auto-description des tribunaux, qui peuvent être observées à la fois comme centre du système juridique et comme organisation périphérique, de plus en plus active dans les systèmes politiques et économiques. Dans cette dernière observation, la thèse présente une recherche empirique sur le comportement décisionnel du Tribunal fédéral suprême sur le cadre du texte constitutionnel de 1988, dans le cadre d'un contrôle concentré de la constitutionnalité des affaires relatives aux droits économiques. Les trois positions différentes d'observation et les données empiriques ont permis l'examen du fonctionnement des tribunaux dans la société et la façon comme le droit brésilien traite les problèmes produits par son milieu sans perdre sa principale fonctionnalité de prise de décisions légales.

Mots-clés: Sociologie du Droit; Droit et Sociéte; Théorie des Systèmes; Argument Conséquentialiste 
PARTE I - ARGUMENTOS CONSEQUENCIALISTAS DO DIREITO EM UMA TEORIA COMPLEXA 40

CAPÍTULO 1 - BASES FILOSÓFICAS DO CONSEQUENCIALISMO E O DIREITO 47

1.1 Consequências como método de tomada de decisão no utilitarismo filosófico 48

1.2 Consequências como forma de significação no pragmatismo filosófico 50

1.3 Heranças do utilitarismo e do pragmatismo filosófico para o direito 53

CAPÍTULO 2 - TEORIAS DO DIREITO 56

2.1 Escolas do realismo jurídico estadunidense 56

2.2 Consequencialismo nas escolas do realismo jurídico estadunidense 63

2.3 Crítica hartiana às escolas realistas e o consequencialismo 69

2.4 Contra-ataques das escolas realistas à crítica hartiana 75

2.5 Teorias do direito pós-Hart 81

CAPÍTULO 3 - TEORIAS EXTERNAS DO DIREITO 84

3.1 Visão da Análise Econômica do Direito 86

3.2 Direito e Economia Positivo 89

3.3 Direito e Economia Normativo 92 
3.5 Pragmatismo jurídico de Posner 95

CAPÍTULO 4 - TEORIAS DA ARGUMENTAÇÃO JURÍDICA 102

4.1 Teorias do argumento consequencialista do direito 109

4.2 Escola de Direito de Edimburgo 112

4.3 Escola de Direito de Amsterdã 117

CAPÍTULO 5 - SOCIOLOGIA SISTÊMICA DO DIREITO 120

5.1 Consequências e o direito na Teoria dos Sistemas

5.2 Críticas ao consequencialismo pela dogmática jurídica 125

5.3 Consequências como funções corretivas do direito 133

5.4 Consequências, juridificação e conceitos jurídicos adequados à sociedade 137

5.5 Consequências, programas finalísticos e argumentação em Direito da Sociedade 142

5.6 Ideias fora do lugar? 147

PARTE II - ARGUMENTOS CONSEQUENCIALISTAS DO DIREITO EM UMA SOCIEDADE COMPLEXA 160

CAPÍTULO 6 - RISCO, PERIGO E CONSEQUÊNCIAS NA SOCIEDADE 170

6.1 Adequação de uma sociedade mundial? 173

6.2 Economização e perigo ambiental da sociedade mundial 182

6.3 Resistências da sociedade mundial frente à economização 193

6.4 Sociedade brasileira: dos anos 1980 até a metade dos anos 2010 196 
7.1 Ciência e sociedade 206

7.2 Ciência pelo direito e pela política?

8.1 Ideia de crise 225

8.2 Metacódigo inclusão/exclusão 228

8.3 Entre inclusão e exclusão: o direito brasileiro como ambiente de uma sociedade complexa

PARTE III - ARGUMENTOS CONSEQUENCIALISTAS DO DIREITO EM UMA ORGANIZAÇÃO COMPLEXA 239

CAPÍTULO 9 - TRIBUNAIS COMO ORGANIZAÇÕES SOCIAIS COMPLEXAS 244

9.1 Fatores estruturais 249

9.2 Forma de organizações 252

9.3 Poder Judiciário em contexto 255

9.4 Tipologias das observações sobre os tribunais na sociedade 256

9.5 Tribunais na sociedade brasileira 270

CAPÍTULO 10 - O SUPREMO TRIBUNAL FEDERAL NA SOCIEDADE BRASILEIRA 273

10.1 Poder do STF após a Emenda Constitucional n. 45/04 275

10.2 Supremo: labirinto recursal, monocrático e corporativista 277

CAPÍTULO 11 - DIREITOS ECONÔMICOS E SOCIAIS, ARGUMENTAÇÃO CONSEQUENCIALISTA E SUPREMO TRIBUNAL FEDERAL 283 
11.1 Legitimidade dos juízes 286

11.2 Capacidade institucional 288

11.3 Problemas do consequencialismo na adjudicação 294

CAPÍTULO 12 - DECISÃO SOBRE O FUTURO: CONTROLE CONCENTRADO DE CONSTITUCIONALIDADE DOS DIREITOS ECONÔMICOS (1988-2017) 299

12.1 Recortes, métricas e composição da amostra 301

12.2 Análise quantitativa 305

12.3 Análise qualitativa 317

CONSIDERAÇÕES FINAIS 327

REFERÊNCIAS BIBLIOGRÁFICAS 337

ANEXOS 366 


\section{INTRODUÇÃO}

Argumentos consequencialistas estão presentes em diferentes discussões legais e desafiam o funcionamento dos tribunais, ultrapassando as fronteiras do direito e implicando novas seleções e estabilizações.

O tema "direito e consequência" é, tradicionalmente, apresentado de três maneiras. Primeiro, como um campo inerente ao estudo da norma jurídica - i.e., consequência como consequente normativo da estrutura da regra. Segundo, como desdobramento dentro do direito. Trata-se das consequências jurídicas num duplo sentido; um deles é o andamento regular do processo, enfatizando-se os atos processuais das partes, das autoridades - e.g., sentenças, decisões interlocutórias e despachos -, do escrivão e da secretaria. O outro são os desdobramentos a partir do conjunto de decisões passadas e textos legais, salientando-se os efeitos da decisão no ordenamento jurídico. Em terceiro lugar, direito e consequência também pode ser estudado por seu desdobramento fora do direito, discutindo-se as consequências extrajurídicas, fáticas ou sociais desencadeadas - e, muitas vezes, incontroláveis - pela decisão jurídica.

A tese avança neste tema pelo campo da sociologia jurídica, e desafia esta caracterização ao apresentar três diferentes posições de observação sobre o argumento consequencialista em juízo. Neste sentido, a consequência é aqui tratada como argumento e a partir da operação dos tribunais.

A título de exemplo no Poder Judiciário brasileiro, ${ }^{1}$ no controle judicial de questões sociais e de políticas públicas é comum que juízes e tribunais recorram às consequências

\footnotetext{
${ }^{1}$ Pesquisas realizada em 2005 e em 2015 pela Associação dos Magistrados Brasileiros (AMB) formularam a seguinte pergunta para um conjunto de magistrados: "Do seu ponto de vista, as decisões judiciais devem orientar-se preponderantemente por parâmetros legais, atentar para as suas consequências econômicas ou ter compromisso com suas consequências sociais?" A principal conclusão obtida no relatório foi: "Chamados a decidir sobre questões que têm reflexos diretos sobre a economia e o desenvolvimento social do país, os juízes brasileiros (...) baseiam-se preponderantemente na lei, sem ignorar as consequências econômicas e sociais de suas sentenças" (ASSOCIAÇÃO DE MAGISTRADOS BRASILEIROS, 2005). A mesma tendência se observou dez anos depois, com uma preocupação cada vez maior em relação às consequências econômicas, sobretudo nas instâncias superiores: "É significativo o contraste entre as instâncias no que se refere à repercussão econômica das decisões. Quanto mais se sobe na hierarquia, mais a repercussão econômica é levada em conta. Assim, a opção "leva muito em conta" soma 6,4\% no 1o grau, cresce para 19,8\% no 2o grau e chega a $51,7 \%$ nos tribunais superiores. Essa questão é mais bem avaliada quando se leva em consideração os extremos, isto é, "não leva em conta" e "leva muito em conta". A opção "leva adequadamente em conta" admite maior margem de interpretação" (ASSOCIAÇÃO DE MAGISTRADOS BRASILEIROS, 2015).
} 
para justificar suas decisões - situações nas quais as autoridades baseiam-se nas consequências fáticas futuras de suas sentenças; assim é que o Supremo Tribunal Federal (STF), ancorado em estudos técnico-científicos, declarou constitucional a lei que proíbe a importação de pneus usados em razão de possíveis adversidades à saúde pública, ${ }^{2}$ ou, por questões orçamentárias, deixou de reconhecer a obrigatoriedade de realização de certos tipos de cirurgias pelo Sistema Único de Saúde ${ }^{3}$, ou, ainda, julgou constitucional determinada lei cujo intuito é coibir a violência no âmbito das relações familiares. ${ }^{4}$ Vale mencionar também que o STF deixa de decidir com base nas consequências, como no caso dos planos econômicos. ${ }^{5}$

Em todos estes casos, o juiz, ao decidir, acaba considerando em alguma medida as consequências de sua decisão de diferentes maneiras, seja para enfrentá-las ou não na tomada de decisão. Admite-se, nesta tese, que uma das formas de raciocínio jurídico é a que se desenvolve por meio dos argumentos de consequência ou do argumento consequencialista, aquele operado pelo tribunal a partir das consequências da decisão, independentemente do tipo de consequência que tenha sido admitido e avaliado pela decisão.

Cabe esclarecer, neste ponto, que isso não significa que toda e qualquer autoridade esteja preocupada com as consequências no processo de tomada de decisão - ainda que para alguns modelos da argumentação seja obrigatória a explicitação dos motivos de fundo que justificam a tomada de decisão, como desdobramento do corolário do império do direito

\footnotetext{
Outro exemplo que aponta a preocupação com as consequências no processo de tomada de decisão pelo direito brasileiro é o Projeto de Lei do Senado no 349, de 2015, de autoria do Senador Antonio Anastasia, que contou com a contribuição dos professores Carlos Ari Sundfeld e Floriano de Azevedo Marques Neto. O projeto de lei inclui no Decreto-Lei $n^{\circ} 4.657$, de 4 de setembro de 1942 (Lei de Introdução às Normas do Direito Brasileiro), disposições sobre segurança jurídica e eficiência na criação e na aplicação do direito público. Destaca-se o artigo que obriga que a autoridade considerar as consequências na tomada de decisão, diz: "Art. 20. Nas esferas administrativa, controladora e judicial, não se decidirá com base em valores jurídicos abstratos sem que sejam consideradas as consequências práticas da decisão. Parágrafo único. A motivação demonstrará a necessidade e a adequação da medida imposta ou da invalidação de ato, contrato, ajuste, processo ou norma administrativa, inclusive em face das possíveis alternativas" (BRASIL, 2015). O projeto de lei foi aprovado nas duas casas legislativas e aguarda a sanção presidencial. Para um debate geral deste projeto de lei, cf. LEAL; MENDONÇA, 2016.

${ }^{2}$ BRASIL - STF. ADPF 101/DF, Rela. Min. Cármen Lúcia, j. 24.06.2009.

${ }^{3}$ BRASIL - STF. STA 185, Rela. Min. Ellen Gracie, j. 10.12.2007.

${ }^{4}$ BRASIL - STF. ADC 19, Rel. Min. Marco Aurélio, j. 09.02.2012.

5 Para uma descrição detalhada do caso dos planos econômicos a partir do debate dos argumentos consequencialistas cf. BARROS, 2014a. A solução deste caso encaminhou-se para um acordo entre bancos e poupadores, o que afastaria a possibilidade de colapso do sistema financeiro diante do provisionamento de valores estimados em 16 bilhões de reais. Tal situação reforça uma maneira de, ao mesmo tempo, a corte não decidir e evitar o enfrentamento dos argumentos consequencialistas.
} 
(rule of law). ${ }^{6}$ Destarte, o argumento consequencialista tem relevo nesta tese somente quando efetivamente explicitado como razão da decisão e, inclusive, avaliado pela autoridade para chegar à decisão final, tornando públicas suas justificativas. ${ }^{7}$

Desde o resgate e o fortalecimento de correntes sociológicas de tomada de decisão, no final do século XX, aliados à estruturação de teorias da argumentação jurídica como contrapartida do debate promovido pelos realistas estadunidenses, restou esclarecido que juízes e outros tomadores de decisão podem ser influenciados e motivados por determinadas consequências pretendidas.

$\mathrm{Na}$ história do direito, este fortalecimento remonta desdobramentos e debates já antigos entre a corrente da "Jurisprudência dos Interesses", que pretendia elevar o direito ao nível de verdadeira ciência à luz do positivismo científico, reclamando por métodos análogos às ciências naturais, e a "Jurisprudência dos Conceitos", que buscou afastar as aproximações com outras ciências e fundamentar a autonomia do direito e seus métodos. ${ }^{8}$

Deve-se destacar que a aplicação dos argumentos consequencialistas não depende, em tese, de autorização ou previsão legal. ${ }^{9}$ Como qualquer outro tipo de argumento, o juiz pode considerá-lo e, inclusive, avaliá-lo como material relevante para a tomada de decisão em face da particularidade do caso.

O que importa observar é que, ao enfrentar um argumento deste tipo, o tomador de decisão assume o ônus de saber quais são as consequências e de como as avaliar. Se é admitido que um juiz decida com base num argumento consequencialista $\mathrm{X}$, afirma-se que,

\footnotetext{
${ }^{6} \mathrm{O}$ corolário do império do direito exige que toda decisão jurídica deve ser construída a partir de um esquema dedutivo e fundamentada a partir de regras preestabelecidas, o que possibilita a reconstrução e questionamento pelos jurisdicionados, cf. MACCORMICK, 2005.

${ }^{7}$ Razões consequencialistas podem estimular e servir de base para o processo de descoberta da verdade nos processos judiciais. Todavia, a pesquisa concentra-se somente nos argumentos consequencialistas como justificativas das decisões. A tese não segue uma perspectiva realista de análise do processo decisório, que se preocupa em descrever o encadeamento mental por meio do qual juízes recorrem às razões consequencialistas, discutindo os vieses e atalhos cognitivos. Esta análise concentra-se nas observações das operações dos tribunais enquanto organizações sociais. Para um debate sobre descoberta e justificação no direito, cf. SCHECAIRA; STRUCHINER, 2016, pp. 155-174. Também é possível discutir o uso velado deste tipo de argumento como apresentado no ponto 11.3 desta tese.

${ }^{8}$ Para uma apresentação histórica dessas correntes, cf. LARENZ, 1969.

9 É possível notar que em certas áreas do direito o legislador expressamente estabeleceu uma maior proximidade do raciocínio por meio das consequências, caso dos direitos econômico, social, concorrencial e financeiro e de determinados temas, como o planejamento tributário. Pode-se, adicionalmente, sustentar a hipótese de desdobramento do aumento de leis progressistas (ou finalísticas), que dependem da promoção de objetivos determinados pela norma, como adequação entre meios e fins. Neste sentido, destaca-se POSNER, 2008. Para uma discussão a partir do contexto brasileiro, cf. ARGUELHES 2005 e 2006.
} 
ao decidir o caso, o juiz adota uma regra relevante para a tomada de decisão que possui várias consequências possíveis $(\mathrm{A}, \mathrm{B}, \mathrm{C} . .$.$) e, por algum motivo, o argumento \mathrm{X}$ derivado da interpretação da regra relevante é que produzirá consequências favoráveis (A') em detrimento das demais (B', C'...).

Percebe-se, ademais, que as necessárias definição e avaliação para que se alcance esta justificação exigem do juiz um manuseio de um método descritivo. É imprescindível que o tomador de decisão utilize metodologias e métricas suficientes na definição dos critérios para realizar avaliações. ${ }^{10}$

Em compreensão inicial desta tese, depreende-se que argumentar por meio das consequências pelo direito exige da autoridade o domínio e a capacidade de utilizar metodologias de análise que podem, por vezes, ser estranhas ao próprio direito. Pressupõese uma questão de expertise em jogo que permite à autoridade transitar nestes espaços de avaliação.

Esta tese admite, ainda, que o aumento da aplicação do argumento consequencialista em juízo coincidiu com o processo de modernização ${ }^{11} \mathrm{e}$, mais recentemente, com as transformações operadas pela comunicação digital, na sociedade mundial, que implicaram alterações não programadas no sistema jurídico. Tais descrições decorrem da observação da sociedade brasileira como especificação do sistema social global.

Considerando os condicionamentos locais, é possível mencionar algumas razões que justificam esse diagnóstico no contexto brasileiro, tais como o advento da Constituição

\footnotetext{
${ }^{10}$ Para alguns autores, é possível identificar o argumento consequencialista a partir de uma estrutura dual: a primeira como a parte descritiva, na qual a autoridade especifica a consequência associada à decisão, e a segunda como a normativa, a partir da valoração da consequência. Veja SCHUARTZ, 2011.

${ }^{11}$ A tese segue a ideia de modernização seletiva contextualizada para o direito brasileiro por Villas Bôas Filho (2009), Gonçalves (2013a) e Dutra (2016). Villas Bôas Filho aduz que “(...) a modernidade brasileira, ainda que caracterizada como periférica, não pode ser descrita como inexistente ou como negativa, pois isso implicaria valorá-la a partir de um arquétipo ideal e normativo que, acima de tudo, não existe, uma vez que, tal como ressalta Jessé Souza, a modernização é um processo seletivo e, portanto, parcial, o que faz com que nenhum processo completo de sua realização esgote todas as suas virtualidades a ponto de ser tomado como padrão normativo"(2009, p. 295). Dutra também lembra que não é possível falar em um déficit de modernidade no país já que está integrado em uma sociedade mundial, sobretudo por meio de processos de globalização dos sistemas de função, diz "é possível interpretar esta integração do Brasil na sociedade funcionalmente diferenciada como resultado de práticas de comparação entre unidades sociais especialmente distantes em uma mesma sociedade mundial. Com isso, transcendemos a dicotomia espacial externo/interno e definimos este processo de integração como resultado da própria globalização dos sistemas funcionais" (2016, p. 95). A aproximação é, então, que a modernização seletiva, marcada pelo primado da diferenciação funcional da sociedade mundial, constitui o pano de fundo para a observação da expansão dos argumentos consequencialistas no direito apresentada nesta tese.
} 
Federal de 1988 e o aumento de legislações programáticas; ${ }^{12}$ o desenvolvimento de uma nova semântica, sobretudo relacionada à aplicação de conceitos jurídicos indeterminados e de cláusulas gerais; ${ }^{13}$ a abertura para novas tematizações nos tribunais; ${ }^{14}$ a formação de uma nova expertise jurídica (e.g., programadores e engenheira jurídica); a incorporação nas operações de mecanismos baseados em algoritmos (e.g., automação); e a evolução de uma comunicação digital do direito.

Se por um lado houve ampliação do uso da argumentação consequencialista em juízo, por outro constatou-se certa fragilidade dos tribunais em relação à operação dos argumentos - fato relacionado ao déficit do Poder Judiciário em produzir segurança jurídica no Brasil. É dizer, as decisões judiciais no sistema brasileiro encontram dificuldade em estabilizar algumas expectativas normativas contrafáticas, sendo que alguns autores explicam este diagnóstico em razão de forte interferência de fatores patológicos nas decisões judiciais, tais como corrupção, proximidade pessoal ou motivações ideológicas (SCHUARTZ et al., 2006); para outros, contudo, o problema reside na qualidade da justificação das decisões judiciais (RODRIGUEZ, 2013) ou mesmo no déficit operativo estrutural do Poder Judiciário (VILLAS BÔAS FILHO, 2009; CAMPILONGO, 2002).

\footnotetext{
${ }^{12}$ A Constituição Federal de 1988 é um marco temporal de transição entre a ditadura militar, que durou 25 anos, e o estado democrático. Naquele momento de abertura do país, a Constituição estabeleceu um estado regulatório capaz de aperfeiçoar a sociedade democrática, basta pensar na extensão dos direitos econômicos e sociais, que exigem da autoridade uma atuação transformadora. Segue-se os apontamentos de Ferraz Jr., diz: "as tarefas postas ao Estado não só se multiplicaram, mas também se modificaram. Exige-se do Estado a responsabilidade por uma conformação social adequada da sociedade, ou seja, colocam-se para ele outras funções que não se casam plenamente com os tradicionais limites do Estado de Direito" (2007, p. 9). É neste contexto que ao longo das três últimas décadas, verificou-se uma crescente adoção dessas legislações finalísticas - cujo intuito é concretizar os objetivos estabelecidos na Constituição Federal. Para tanto, foi necessário desenvolver técnicas para suas consecuções, dentre as quais se destaca a argumentação consequencialista a fim de analisar a pertinência entre meios jurídicos e fins normativos. Novamente, Ferraz Jr. também discute a partir de uma hermenêutica constitucional orientada para a legitimação vis-à-vis a operação de bloqueio (ibidem).

${ }^{13}$ A possibilidade de recurso ao argumento consequencialista também está relacionada à interpretação e à aplicação de conceitos jurídicos indeterminados e de cláusulas gerais, que, supostamente, carregam alto grau de vagueza semântica, dependendo de uma construção da autoridade para apresentar a solução adequada ao caso concreto. As novas semânticas presentes nos textos legais sujeitam-se à aplicação do intérprete para conseguir uma completa significação. Há uma importante relação entre interpretação e argumentação que a tese não aborda, remete-se aqui para a apresentação em SCHECAIRA; STRUCHINER, 2016.

${ }^{14}$ Após a Constituição de 1988, o Poder Judiciário obteve maior destaque, fortalecendo sua função contramajoritária em relação aos demais poderes - o que se observou especialmente no STF. Enquanto corte constitucional, o STF consolidou-se como instância legítima para arbitrar interesses de minorias e para decidir conflitos institucionais e políticos, desempenhando papel relevante no delineamento das políticas públicas no país e contribuindo para a criação de incentivos e desincentivos para as mais diversas atividades, cf OLIVEIRA, 2016 e 2017; TAYLOR, 2008.
} 
Vale destacar que esta tese adota como premissa o referido diagnóstico de dificuldade operativa; Campilongo e Villas Bôas Filho - baseados na teoria dos sistemas de Luhmann explicam que nas periferias do sistema jurídico brasileiro textos legais não são capazes de evitar o acesso, em juízo, de demandas que não foram suficientemente alocadas em outras instâncias programatórias. Em outras palavras, a periferia dos sistemas jurídicos é incapaz de oferecer aos tribunais o autoisolamento cognitivo, que se veem, portanto, obrigados a fornecer decisões baseadas em programas inexistentes, omissos ou parciais.

Diante deste cenário, coloca-se a hipótese de que o aumento do uso do argumento consequencialista no direito brasileiro reflete não apenas um espectro restrito, em casos para os quais o legislador admitiu essa argumentação ou naqueles em que esta tenha sido efetivamente motivada nas decisões, mas também um emprego arbitrário, passível de provocar uma descaracterização deste argumento no direito. ${ }^{15}$

$\mathrm{O}$ que se pretende, aqui, não é proceder à discussão dogmática ${ }^{16}$ do argumento consequencialista, mas verificar como ocorre funcionalmente sua avaliação e aplicação pelos tribunais brasileiros. Intenta-se examinar o funcionamento dos tribunais e como o direito lida com as questões produzidas por seu ambiente sem perder sua funcionalidade principal de tomada de decisões jurídicas.

Problematiza-se o diagnóstico sobre a crescente utilização de argumentos consequencialistas e seus efeitos no direito brasileiro a partir da observação de alguns julgados. Além de analisar suas operações e apontar seus limites, identifica-se as circunstâncias que a argumentação consequencialista é necessária à aplicação do direito, bem como as restrições e as dificuldades que ela própria coloca para a argumentação nos tribunais.

Para tanto, organizou-se a pesquisa em três partes. Cada uma pode ser considerada

\footnotetext{
${ }^{15}$ Prevalece um grande risco de confusão do argumento consequencialista com situações não autorizadas ou não motivadas que não se relacionam diretamente com o direito. Trata-se de uma fuga do direito, uma vez que estes argumentos exigem o manejo de razões empíricas ou de juízos probabilísticos autorizados pela ordem estatal. Ao não respeitar os limites operativos, a autoridade incorre no perigo de replicar um modelo inconsistente (em termos argumentativos) de decisão e de não produzir segurança jurídica.

16 Para a tese a dogmática jurídica é uma forma de pensamento do direito que está relacionada preponderantemente à aplicação do direito e à resolução de conflitos. Trata-se de uma definição tecnológica e performativa, cf. FERRAZ JR., 2015.
} 
como distintas posições de observação ${ }^{17}$ dos argumentos consequencialistas do direito ${ }^{18}$, ao mesmo tempo em que podem ser admitidas como etapas sucessivas de redução do elevado grau de abstração. A tese segue desdobramentos do referencial teórico mobilizado apresentado na sequência - que defende um modelo de observações multinível, ${ }^{19}$ pois "toda tentativa de descrever a sociedade com base em apenas uma distinção leva a um contraste exagerado e irreal" (LUHMANN, 2013, p. 43).

Acredita-se que o modelo de observações multinível, se devidamente manejado já que pode ser controlado pela posição de observação ${ }^{20}$ e não existem posições

${ }^{17}$ A ideia de posições de observação relaciona-se, nesta tese, com a ideia de referência em Luhmann. Diz o sociólogo que "a referência torna-se observação quando a distinção é usada para adquirir informações sobre o que é indicado (o que, em geral, requer distinções que são mais compreendidas)" (1995a, p. 440, tradução livre). Neste sentido, considerando-se as referências do sistema científico (autorreferências), é possível admitir diferentes posições para observar determinada interação ou sistema da sociedade.

18 Como apontado nas notas metodológicas desta tese, a observação sociológica dos argumentos consequencialistas do direito deve ser parte integrante de uma teoria da interpretação que descreva tanto a autodescrição do direito quanto a da sociedade. Neste sentido, Campilongo sustenta: "A intepretação jurídica não é apenas autodescrição do direito. É, também, olhar do direito sobre a sociedade e da sociedade sobre o direito. Somente daí é possível extrair uma descrição sociológica da interpretação jurídica à altura da complexidade social" (2012, p.134).

${ }^{19}$ Este modelo se relaciona com a distinção dos níveis de interação entre os sistemas. Explica Luhmann: "A teoria dos sistemas sociais nos permitirá fazer essa distinção entre micro nível e macro nível de forma mais precisa. Tratam-se de diferentes níveis e processos de formação do sistema, sendo realizados simultaneamente e com referência uns aos outros. No nível de interação, os sistemas sociais surgem porque a comunicação implica seleção e a presença de outras pessoas torna inevitável a comunicação. No plano social, os sistemas sociais surgem devido ao fato de que, em toda a interação, deve assumir-se que os participantes também atuam em outras relações sociais. A sociedade - como a totalidade de todas as ações e experiências comunicativamente disponíveis (porém indiretamente realizáveis) - é, em si, um sistema social; também se baseia em estruturas seletivamente constituídas - na sua auto-implicação - e em limites que excluem um ambiente estranho" (2015, p. 235, tradução livre).

${ }^{20}$ Como apontado na nota 17 , a posição de observação é uma variável que controla as diferentes formas de referência e, portanto, o grau de abstração, por assim dizer, relaciona-se com as diversas referências. Nesta teoria, a distinção principal é entre heterorreferência e autorreferências. Importa para o sistema científico perceber as diferentes referências produzidas e operadas sobre a sociedade, que, simultaneamente, estão nela situadas, de modo que seu esclarecimento é etapa fundamental em qualquer investigação científica. Luhmann argumenta que a ciência não pode escolher a sociedade em que faz sua autorreferência, tampouco é permitido que se observe a sociedade de fora, admitindo-a como um objeto a ser melhorado de acordo com o avanço do conhecimento. Cabe somente à ciência, a partir de suas estruturas, produzir suposições sobre o seu ambiente (1996, pp. 256-260) — para esta, o mundo torna-se um substrato vagamente acoplado que, sucessivamente, é reconstruído a partir do código "verdade/falsidade". Aduz, ainda, que "o código [da ciência] define um mundo e ao mesmo tempo define operações que, por sua vez, determinam um sistema que delimita do mundo para poder observá-lo" (ibidem, p.224, tradução livre).

É neste sentido que a tese segue a distinção dos "três níveis de autorreferrência" do sistema; segundo Luhmann, é possível diferenciar observações sobre a autorreferrência basal (distinção entre elemento e relação), a reflexividade (distinção entre antes e depois) e a reflexão (distinção entre sistema e ambiente) (1995a, pp. 442448). A sugestão, aqui, é que quanto mais distante da relação basal, mais difícil a reconstrução da rede referencial pressuposta pela observação científica. Logo, o grau de abstração é uma variável resultante da relação entre capacidade de reconstrução da observação e nível de autorreferência do sistema observado - o que é definido pela posição de observação e pelo observador. 
privilegiadas $^{21}$-, possibilita o controle das abstrações inerentes ao referencial sistêmico. Afinal, nesta teoria, a sociedade pode ser observada como um complexo sistema de interações, sendo fundamental, para o pesquisador, reduzir e respeitar a ordem das interações basais até as mais distantes à luz de um modelo que diferencia e integra macro e micro níveis de observação.

É dizer, se for possível estabelecer uma gradação multinível, passa-se, primeiro, da observação do nível teórico (mais abstrato) para o nível da sociedade e, depois, para o nível organizacional (menos abstrato). Com efeito, as partes desta tese sobrepõem-se e complementam mutuamente, pois apresentam diferentes observações e enfrentam pontos cegos das outras e, simultaneamente, discorrem sobre elas a partir das experiências de um único observador. Obviamente, nestas posições outros pontos cegos surgirão e muito deixará de ser observado.

Na primeira parte, denominada "Argumento Consequencialista do Direito em uma Teoria Complexa", é apresentada, para contextualização do objeto da tese, a divergência a respeito da noção de consequencialismo. Alguns autores - para além do utilitarismo e do pragmatismo filosófico - preferem tomá-lo como sinônimo de aplicação direta de razões extrajurídicas para a tomada de decisão, sem respeito a algum critério de adequação (ou forma) jurídica, admitindo-se certa colonização externa do direito ou ocultação por ele produzida. Trata-se de um verdadeiro consequencialismo implacável viabilizado por formas não jurídicas. Posicionamentos semelhantes são encontrados em autores do começo do século XX do realismo jurídico estadunidense (e.g., Karl Llewellyn e Jerome Frank), e reformulados em outras teorias externas sobre o direito como a Análise Econômica do Direito (e.g., primeira fase de Richard Posner e de Guido Callabresi) ou o pragmatismo jurídico (e.g., segunda fase de Richard Posner).

Não obstante, há perspectivas que diferenciam o consequencialismo com o uso mediado pelo direito de argumentos consequencialistas como etapa necessária da justificação (e.g., Neil MacCormick, Zenon Banwoski, Jerzy Wróblewski e Eveline Feteris). Trata-se, aqui, de teorias da argumentação jurídica que discutem a aplicação destes argumentos observando os limites do sistema jurídico.

\footnotetext{
${ }^{21}$ Diz Luhmann discutindo os diferentes níveis de interação na sociedade: "o micro nível e o macro nível são de igual status; nem pode prevalecer um sobre o outro. Todas as afirmações que reivindicam validade ou aplicabilidade universal devem, em vez disso, ser trazidos no âmbito de uma teoria geral dos sistemas sociais que lidam com o surgimento de uma ordem especificamente social como tal” (2015, p. 236, tradução livre).
} 
Considerando-se o propósito central desta pesquisa, vale destacar que, do ponto de vista sistêmico, a visão da teoria do direito contribui para o entendimento de como o direito observa o argumento consequencialista - trata-se da reflexão interna do próprio direito -, de modo que a apresentação do desenvolvimento teórico do tema tem como intuito esclarecer a distinção semântica - forma de variação de sentido - produzida pelo sistema jurídico, que opera cada vez mais com base nas consequências.

Na segunda parte, "Argumentos Consequencialistas do Direito em uma Sociedade Complexa", observa-se como esta distinção semântica reflete também as operações da sociedade mundial a partir de conceitos que repercutem a dificuldade de lidar com o futuro - tempo das consequências -, como "risco/perigo", "exclusão/inclusão" ou a forma de “crise/estabilização". Isto porque o tipo de argumentação em destaque na tese exige previsões, limitadas, temporalmente, na própria possibilidade de operação do direito, em especial quando se considera que este é dirigido pelo passado e suas operações ocorrem no presente. $^{22}$

Argumenta-se que a solução encontrada na sociedade mundial para operar com o futuro foi sua integração com uma "sociedade" de experts, modelo reforçado e aplicado nos anos 1990 no Brasil sob os auspícios do Consenso de Washington e de uma agenda reformista do governo federal, sobretudo diante do esgotamento do modelo welfarista.

Na prática, as formas de expertise são comunicações das autoridades e organizações que recorrem ao conhecimento científico para a tomada de decisão; são, geralmente, especialistas em sua área de atuação e reconhecidos pela comunidade científica. Nesta compreensão, acredita-se que tais profissionais estejam em uma posição privilegiada para decidir questões consequencialistas, pois, além de sua credibilidade e de gozarem de certa experiência técnica, muitos participam dos círculos de poder, em fóruns mundiais, agências, ministérios, tribunais, universidade ou empresas. A tese destaca que os experts estão, na verdade, situados fora do conhecimento e no poder, definindo os rumos da sociedade mundial numa conjuntura de governança global diante dos efeitos da economização, que se desdobram como perigos ambientais para outros subsistemas sociais.

\footnotetext{
${ }^{22}$ Desta forma, para o direito, o futuro segue desconhecido, pois é sempre um presente futuro e que apenas se atualiza como um futuro presente quando algum texto legal antecipa e condiciona como conteúdo jurídico como exemplificado no argumento da batalha naval de Aristóteles. Para uma discussão geral sobre tempo e direito a partir do referencial da teoria dos sistemas, cf. ANGELELLI, 2017.
} 
Se por um lado é possível observar uma extrema valorização dessa "sociedade" que atribui a experts e órgãos especializados grande autonomia para a tomada de decisão orientada para o futuro, por outro este modelo baseado na atuação destes profissionais oculta diversos problemas e tensões. Argumenta-se, ainda, que o comportamento dos experts reproduz desigualdades e injustiças ao distribuir recursos e ganhos pela sociedade, notadamente inclusão pelo risco e exclusão pelo perigo. No caso do enfrentamento dos argumentos consequencialistas do direito, prevalece um paradoxo, pois, ao mesmo tempo em se admitem, cientificamente, a neutralidade e a universalidade da expertise, também se observa o exercício de um poder parcial e enviesado que justifica suas posições ${ }^{23}$ e a exclusão pela decisão em outros sistemas.

A tese admite que o direito, por meio da circulação da comunicação dos experts, permite a tradução da ciência para tomada de decisão e redução dos perigos ambientais, sobretudo ao lidar com os argumentos consequencialistas. Todavia, esta articulação não é clara, sobretudo se for considerado o paradoxo apontado. Afinal, como o direito relacionase com experts e observa sua operação a partir de si mesmo?

Na última parte, “Argumentos Consequencialistas do Direito em uma Organização Complexa", esta pergunta é encaminhada por meio da análise de julgados sobre casos de direitos econômicos em sede de controle de constitucionalidade do STF. A amostra constitui importante representação da atuação do STF enquanto corte constitucional - em tese, com maior sensibilidade operativa em relação aos perigos ambientais, sobretudo aos sistemas político e econômico, além de fácil acesso à expertise ${ }^{24}$ - que opera com argumentos

\footnotetext{
${ }^{23}$ Kennedy aponta que "os experts possuem pontos cegos e preconceitos, sobrestimam suas perspectivas e colocam fé no potencial da sua disciplina acima de uma avaliação cuidadosa de suas realizações. Eles aprenderam a ver ordem e sistema no mundo em vez das lutas, e muitas vezes experimentam sua experiência como certa e persuasiva, compreendendo a plasticidade, ambivalência e natureza conflituosa do conhecimento de detêm" (2016, p. 277, tradução livre). Veja também Mattei e Nader (2008).

${ }^{24}$ Sob uma observação sistêmica, o STF é um locus privilegiado para captar as sensibilidades advindas do ambiente do direito brasileiro, notadamente nos âmbitos político - ao debater a Constituição - e o econômico - ao interpretar contratos. Analisar as decisões deste tribunal, que opera seletivamente de maneira autorreferente (consistente juridicamente), mas também heterorreferente (por absorver a complexidade do ambiente), permitirá que se descreva como argumentos consequencialistas estão sendo mobilizados pelos ministros no julgamento de casos concretos. Nesta leitura, pode-se aventar que o STF acaba desenvolvendo uma irracionalidade jurídica em favor de uma maior efetividade do caso concreto, que se pauta exclusivamente em consequências extrajurídicas em detrimento da observação dos limites operativos do subsistema jurídico. Uma importante pesquisa neste sentido é a obra de Lima (2015), que estuda a judicialização constitucional do direito à saúde. $\mathrm{O}$ autor indica a inaptidão técnica do STF ao atuar para formular e implementar políticas públicas de saúde e aponta que os resultados têm sidos desastrosos, já que se privilegia o acesso daqueles bem situados socioeconomicamente, que possuem meios e condições de acesso à justiça, em prejuízo do desenvolvimento de atividades preventivas. De uma outra perspectiva, trata-se também de compreender os perigos do substancialismo jurídico, cf. REIS, 2017.
} 
consequencialistas.

Importa saber como o tribunal utiliza o argumento consequencialista na sua decisão, sendo relevante verificá-lo por meio de análises quantitativa e qualitativa. Como ministros identificam e avaliam as consequências? Como eles operam com metodologias, dados probabilísticos e pareces técnicos? Neste diapasão, a tese avança em uma tipologia sobre os tribunais a partir da observação da comunicação organizacional e distinta daquela do direito, a qual permite compreender a utilização de argumentos consequencialistas em juízo, bem como precisar o fenômeno da expansão do tribunal para além do direito.

Ao final, com cerne nestas três posições de observação, restará demonstrado que o argumento consequencialista reflete uma nova dinâmica dos tribunais na sociedade.

Inclusive, o título da tese reforça as três posições de observação e essa reflexão. Tribunais, enquanto organizações sociais, ultrapassam os limites do sistema jurídico, produzindo outra comunicação ressoante, para além do direito. Da mesma forma, as decisões reforçam o paradoxo desdobrado pelos tribunais no direito, não apenas relacionado com o paradoxo da decisão. A comunicação dos tribunais circula de modo autorreferente e heterorreferente, desafiando a compreensão de como ocorrem as interações com os outros sistemas de função e entre as organizações.

A tese sustenta, primeiro, que há sempre redução e aumento de complexidade. A complexidade se refere às seleções e possibilidades das operações dos tribunais, que é continuamente desdobrada em novas possibilidades, sobretudo em uma sociedade diferenciada funcionalmente e heterárquica. Segundo, os tribunais redefinem seus próprios limites a todo instante e podem ser observados, simultaneamente, tanto como centro do sistema jurídico quanto como organizações periféricas, cada vez mais atuantes nos sistemas político e econômico. 


\section{NOTAS METODOLÓGICAS}

Antes de avançar, é preciso esclarecer alguns aspectos metodológicos da tese para o leitor. Revela-se, neste ponto, que não é possível fazer pesquisa em direito reproduzindo padrões não científicos, naturalizando problemas locais e isolando-se de outros conhecimentos. ${ }^{25}$ Inversamente, pesquisadores em direito devem alcançar outros saberes e aceitar os estranhamentos inerentes ao processo da investigação.

Como já mencionado, esta pesquisa possui viés sociológico. A preocupação não reside em testar os argumentos consequencialistas - discussão reservada à dogmática jurídica -, mas em compreender como ocorre sua aplicação no direito brasileiro. ${ }^{26} \mathrm{~A}$ sociologia jurídica permite que se proceda a uma descrição atualizada desta complexidade observada no direito, apontando os paradoxos e os modos pelos quais as consequências são desdobradas e transformadas, mormente com base na teoria dos sistemas abertos e fechados de Niklas Luhmann. ${ }^{27}$

A mobilização deste instrumental justifica-se, nesta tese, a partir de duas razões. Primeiramente, Luhmann foi um crítico da visão consequencialista do direito, sobretudo por sua descrença na operação de programas finalísticos pelo direito, sempre condicionados aos códigos e resolvidos, no limite, por regras de competência dos juízes - mesmo que programas que fixam os conteúdos de adjudicação aprioristicamente não tivessem sido explicitamente condicionados. É por isso que na visão luhmanniana as consequências são

\footnotetext{
${ }^{25}$ Um importante desafio acerca da pesquisa jurídica no Brasil é superar certa tradição bacharelesca predominante nos programas de pós-graduação que decorre da reprodução pelas pesquisas do abismo entre o direito de manuais e códigos e o direito praticado por advogados e tribunais. Em outras palavras, há uma ruptura presente nas descrições entre um direito idealizado e outro empiricamente constatado. Porém, esta situação não é muito explorada em pesquisas em direito no país - revelando a fragilidade desses trabalhos, como explicam Kant de Lima e Baptista: "O campo jurídico não se permite ser descrito ou analisado de forma diferente, assim como não quer ter de incorporar em sua estrutura as suas descrições. Com isso, acaba ficando sempre igual" (2014, p. 6).

${ }^{26}$ A tese não pretende sustentar um modelo específico de argumentação consequencialista e tampouco defender uma teoria da argumentação. Na parte I, por exemplo, apresenta-se as descrições que o próprio direito produz com o intuito de entender o desenvolvimento do sistema jurídico. A relevância é observar e compreender os paradoxos e limites da argumentação consequencialista no direito.

${ }^{27}$ É importante esclarecer de início que existem diferentes fases e abordagens da sociedade em Luhmann. A versão atualizada desta teoria se encontra na obra Sociedade da Sociedade (2007a), publicada pela primeira vez em 1997. No entanto, o sociólogo alemão também produziu uma série de observações sobre cada sistema social - e.g., direito, economia, religião, politica, arte, saúde, amor etc. A tese admite estes outros desenvolvimentos teóricos que possibilitaram a renovação do modelo e aplicação deste para situações não contempladas nas observações de Luhmann.
} 
tratadas pelo direito de maneira seletiva e via argumentação, esta que deve ser compreendida como “(...) a auto-observação do sistema jurídico que, em seu contexto recursivo autopoiético, reage às diferenças de opinião passadas ou vindouras, no tocante à atribuição de valores do código lícito ou ilícito" (2016, p. 469).

Em segundo lugar, este instrumental é construído em oposição a uma visão ontologizante e subjetivista da sociedade, muitas vezes vinculada à semântica racionalista da Ilustração, baseada na ação racional centrada em sujeitos - o que justifica a sua aversão ao antigo "Iluminismo Sociológico" 28 -, possibilitando que se repense o tema direito e consequência de outra forma.

É importante esclarecer que para Luhmann sociedade é o sistema social mais abrangente e está delimitada pelos limites da comunicação, não por limites territoriais, políticos ou culturais (1995a). Desta forma, qualquer comunicação pode, em princípio, estar relacionada a qualquer outra comunicação e, independentemente, dos limites espaciais, existe apenas um sistema social global: a sociedade mundial moderna. Todo o debate sobre as consequências do direito nesta tese se insere neste contexto mais amplo.

$\mathrm{O}$ tratamento das consequências pelos sistemas sociais deve respeitar e observar os limites semânticos, as possibilidades e os paradoxos produzidos pelos sistemas, não obstante sejam descritos de maneira contingente. ${ }^{29}$ E é por isso que Luhmann sustenta, ao inaugurar

\footnotetext{
${ }^{28}$ Em seu texto de 1967, Luhmann admite uma separação entre a sociologia do Iluminismo "ingênuo" e o seu modelo diante do problema da redução da complexidade. A questão, passa, então, por observar um necessário esclarecimento da sociologia e por evitar duas premissas equivocadas da Ilustração, a saber, "a participação igual de todos os homens numa razão comum que eles possuem sem ulterior mediação institucional, e o optimismo, certo do seu triunfo, em relação ao estabelecimento de situações justas" (2005a, p. 21). Neste texto, o sociólogo também defende que esta "nova" sociologia ilustrada é uma sociologia da sociologia, diz "[u]ma sociologia da sociologia não pode servir para facultar à investigação sociológica verdades deduzíveis e fundamentadas através da garantia das condições de verdade. Tal seria apenas uma repetição da tentativa antiga de, pela redução dos campos de investigação a uns quantos conceitos fundamentais e axiomas simples, bloquear o problema da complexidade, em vez de o levantar. Se, pelo contrário, a sociologia se conceber como ciência de orientação funcional, uma aplicação desta ciência a si mesma só pode significar, por seu turno, análises funcionais, isto é, análise da sociologia como de um sistema particular que apreende e reduz a complexidade" (ibidem, p. 69). Em acréscimo, a crítica a esta visão também foi explorada na obra sobre o sistema científico; o autor pontua que ciência e sociedade não podem ser desvinculadas, já que a ciência não está em posição superior de observação externa à sociedade, portanto, "isto modifica todas as ideias que poderiam ser associadas ao conceito de ilustração sociológica, que admitem poder deduzir e operar com um acesso privilegiado da realidade" (LUHMANN, 1996, p. 438, tradução livre).

${ }^{29}$ Contra a perspectiva tradicional que identificava o consequencialismo como uma visão da consequência da ação, seguindo uma leitura sobre a determinação causal entre input/output, para Luhmann não há certeza que tal consequência acontecerá e tampouco é possível afirmar que a causa foi uma relação de troca com seu ambiente. Na verdade, ele sustenta que "os sistemas operam de maneira recursiva (são operativamente fechados) e seguem com base no estado que atingiram. Suas próprias operações são guiadas pelo passado
} 
o campo de sua teoria, que "[a] complexidade social, juntamente com os esforços da sua apreensão e redução, é um estado de coisas que a sociologia encontra no mundo e investiga" (2005, p. 69).

Cabe esclarecer que a contingência ecoa na teoria dos sistemas como um desdobramento da teoria da complexidade - já mencionada na introdução desta tese, que consiste na observação das diferentes possibilidades de seleção capazes de acontecer nos sistemas entre os seus elementos. Em Luhmann, sistemas (não somente os funcionais) reduzem a complexidade do ambiente por meio de seleções que, na verdade, se apresentam sempre como alternativas disponíveis a futuras seleções e, simultaneamente, como frustrações. $^{30}$

É possível, em verdade, afirmar que a contingência permite perceber como esta teoria foi erigida a partir de uma racionalidade dos paradoxos. Ao aplicar uma lógica da diferença do matemático George Spencer Brown para observar a sociedade, Luhmann confirma que toda a observação é uma distinção que constrói (lado marcado) e destrói (lado não marcado). Constrói, pois, todo conhecimento possível é o conhecimento sobre o observador, que é um sistema. Paradoxalmente, destrói já que prevalecem simultaneamente pontos-cegos, que exigem o desdobramento da observação. ${ }^{31}$

A ideia já é bem conhecida, não há pontos de partidas e nem chegadas na teoria dos

(imediato). Eles não podem ter acesso ao seu futuro. Por isso, eles se movem para trás no futuro". O autor considera, ainda, que os sistemas possuem memórias, o que permite a realização de cálculos e a modificação de expectativas, "as operações auxiliadas pela memória não podem levar tudo o que examinam como sendo simultâneas [entre sistema e ambiente], pois isso levaria a sobreposições insuportáveis, à confusão, à inconsistência e à desorientação" (2006, p. 35, tradução livre).

${ }^{30}$ De Giorgi aproxima complexidade e contingência, diz: "Complexidade significa, portanto, na prática, diz Luhmann, obrigação de operar uma seleção, enquanto contingência significa perigo de desilusão, necessidade de ir de encontro a riscos uma vez que a seleção tenha sido efetuada" (2017, p. 223).

${ }^{31}$ A cibernética só reforça o ponto, pois paradoxos não são resolvidos, mas apenas desdobrados em novas observações que resultam em novos pontos-cegos, sejam observações de segunda ordem, terceira, quarta etc. - e.g., este ponto é também conhecido como o problema do observador. De Giorgi comenta: "É possível sair, liberar-se desses paradoxos? A lógica não nos ajuda. A lógica, dizia Luhmann, pode ver somente o fato de que algumas expressões, a cuja verdade esta não pode renunciar, entram em contradição com outras expressões para as quais vale a mesma coisa. Mediante manobras logicas, o problema não pode resolver-se. Como na terapia sistêmica se pode somente buscar, com a ajuda de Gegenparadoxierugen, um lugar menos doloroso no qual o problema possa ser tolerado" (2007, p. 30), e mais adiante pontua que "Em torno a Luhmann podem construir-se outros paradoxos; outras histórias se podem contar. Desta maneira evitamos o problema do observador, que é o problema da latência. Isto é, o fato de que o observar, como diz Luhmann, visto como operação, deve usar uma distinção que, no momento da operação, não pode indicar porque não pode distinguir. E, efetivamente, nós observamos distinções que um observador usa para indicar alguma coisa e que no momento de sua utilização são inobserváveis" (ibidem, p.31). 
sistemas. Nesta relação paradoxal, que afasta ontologias e filosofias dos sujeitos, ${ }^{32}$ os sentidos - numa aproximação fenomenológica $-{ }^{33}$ são produzidos como a unidade da distinção e sempre desdobrados em um futuro incerto, em especial via comunicação na sociedade. É por isso que ideias como certeza, totalidade, determinação e universalidade, por assim dizer, não se ajustam bem com o linguajar sistêmico, pois escapam do ponto de observação do déficit de racionalidade da sociedade. ${ }^{34}$ Numa sociedade caracterizada como fragmentada e heterárquica, a observação é marcada por paradoxos e tautologias e é preferível incluir ideias como incerteza, parcialidade, indeterminação e seletividade.

Sob outro ponto de vista, considerando-se a dimensão temporal dos sistemas - i.e., observações dos sistemas a partir do par passado/futuro -, a contingência apresenta-se como um horizonte de possibilidades sobre a observação do futuro. A epígrafe desta tese corrobora justamente este ponto ao retomar o famoso argumento da batalha naval de Aristóteles, que demonstrou a impossibilidade de se aplicar o princípio da bivalência para os futuros contingentes. $\mathrm{O}$ argumento da batalha naval, onipresente na observação das consequências na sociedade, foi comentado por Luhmann, que sustentou a importância de se diferenciar o presente do futuro e o futuro do presente, distinção subjacente a todas as ponderações desta tese. $^{35}$

Na visão sistêmica, tempo é uma construção (ou dimensão) social do sentido a partir da distinção passado/futuro feita no presente e por cada sistema. Nesta chave prevalece uma

\footnotetext{
${ }^{32}$ Clam sustenta que opera um elemento deontologizante na teoria dos sistemas, diz "O nível mais exigente no entorno dessas concepções pós-ontológicas é alcançado pela teoria sistema de Niklas Luhmann. Ela representa a concepção mais rigorosa e mais desenvolvida de uma identidade puramente operativa, absolutamente contingente, que sempre escapa a si mesma, não idêntica" 2006, p. 274).

${ }^{33}$ A aproximação fenomenológica do sentido é apresentada como aquilo que é observável e experimentado. $\mathrm{Na}$ perspectiva sistêmica, o sentido é tratado em três dimensões: social; matéria e temporal. Todavia, esta aproximação não se limita à intencionalidade do sujeito, Luhmann amplifica para todos os sistemas que se constituem e operam por meio do sentido (e.g., psíquico e social). Diante de tanta contingência, o propósito da sociologia é, por assim dizer, observar e compreender a estabilidade fenomênica da sociedade. Para uma discussão nesse sentido, cf. CLAM, 2006.

${ }^{34}$ Cf DE GIORGI, 2016.

${ }^{35}$ Luhmann pondera que "[o] que está no futuro não pode ser observado. Isso induziu Aristóteles a perguntar como os julgamentos sobre o futuro poderiam ser feitos usando termos como a verdade e a falsidade. A resposta é, naturalmente, que o julgamento deve não ser decidido. Embora o código binário verdadeiro/falso seja universalmente válido, as decisões sobre futuros contingentes podem simplesmente não ser feitas ainda. Isso, por vezes, foi interpretado como exigindo um terceiro valor lógico, o de indecidibilidade. Pode-se também afirmar que é necessário estabelecer uma distinção entre o presente futuro (quando o prognóstico é feito) e o futuro presente (o momento em que o evento ocorre)" (2006, p. 73, tradução livre), veja também LUHMANN, 1976.
} 
pluralidade de tempos e, em uma sociedade policontextual - i.e., marcada pelos diversos âmbitos de comunicação -, o desafio é articular as desarmonias temporais entre os sistemas (LUHMANN, 1976, pp. 149-152). Trabalha-se, assim, com uma noção fenomenológica de tempo - i.e., temporalização de experiências - diferenciando-se da noção de tempo cronológico (contínuo) ou de tempo modalizado (organizado), ${ }^{36}$ e o interesse recai em observar como os sistemas "desfuturizam" o futuro e operam na sociedade policontextural. ${ }^{37}$ Pelo exposto, a capacidade heurística desta teoria adquire outra orientação. No caso da aplicação de argumentos consequencialistas pelo direito, o interesse desloca-se para a observação da coevolução, da dependência e independência simultâneas, entre sociedade e direito, implicando a diferenciação entre presente do futuro e futuro do presente do direito. De um lado, um direito "prospectivo", que imagina e tenta antecipar o futuro por meio da argumentação. Do outro, a sociedade e suas tecnologias - i.e., inovações como processos de significação -, que buscam confirmar o futuro presente. Revelam-se, assim, tensões e excessos de possibilidades entre direito e sociedade.

Vale, ainda, resgatar um contexto geral desta teoria para o leitor não familiarizado. Sem a pretensão de resumir esta complexa teoria, marco de uma transformação no campo

\footnotetext{
${ }^{36}$ Diz Luhmann: "Proponho definir o tempo como a interpretação da realidade em relação à diferença entre passado e futuro. Esta definição pressupõe, é claro, que a vida cotidiana ocorra como experiência da mudança e contém em si o ponto de partida para a sua própria cronometragem. Eu poderia provar esse pressuposto por análises fenomenológicas. Esta experiência de mudança, no entanto, ainda não é realmente o tempo, como o próprio Husserl viu nos últimos anos. É penetrante e inevitável. Se você não vê ou ouve nenhuma mudança, você sentirá isso em si mesmo. É o dote da vida orgânica pelo seu casamento com a cultura. E predetermina a universalidade do tempo no nível cultural. Mas permanece em geral aberto para a elaboração e variação cultural, precisamente porque é uma predisposição universal para temporização de experiências" (ibidem, p.135, tradução livre).

${ }^{37}$ É importante observar como este ponto se relaciona com as distintas temporalidades desenvolvidas pelos sistemas. É por meio da produção semântica que cada sistema consegue condensar sentido e orientar temporalmente as suas operações. Nesse sentido, as operações são eventos que são reproduzidos constantemente pelo sistema. Graças a reprodução e a formação de expectativas que é possível observar a diferença temporal dos sistemas. Sobre a temporalidade, diz Luhmann: "A temporalização da complexidade vem da temporalização dos elementos de um sistema. O sistema é formado a partir de elementos instáveis, que apenas duram por um curto período de tempo ou mesmo, como ações, não têm duração própria, mas acontecem com sua realização. Observados cronologicamente, cada elemento, é claro, ocupa uma certa quantidade de tempo do relógio. Mas o próprio sistema determina o comprimento do tempo durante o qual um elemento é tratado como uma unidade que não pode ser mais dissolvida; esse período tem um caráter conferido (experimentado), não ontológico. Desta forma, um sistema adequadamente estável é composto de elementos instáveis. Ele deve sua estabilidade a si mesmo, não aos seus elementos; ele se constrói a partir de uma base que não é inteiramente disponível, e este é precisamente o sentido em que é autopoiético" (1995a, p. 48, tradução livre). Para uma apresentação geral da ideia de tempo e o direito na teoria dos sistemas, cf. ANGELELLI, 2017.
} 
da história da teoria social, ${ }^{38}$ basta reconhecer que em Luhmann o direito (sistema funcional) também é observado como uma diferença em relação à sociedade (ambiente). De acordo com esta visão, o direito não está fora da sociedade, mas está na sociedade funcionalmente diferenciada, é subsistema do sistema da sociedade, diz o sociólogo " a sociedade não é simplesmente o ambiente do sistema legal. Em parte, ela é mais, à medida que inclui operações do sistema jurídico, e em parte, menos, à medida que o sistema do direito tem a ver também com o ambiente do sistema da sociedade" (2016, p. 74).

Direito e sociedade não se confundem, mas se pressupõem na medida em que não é possível observar o direito sem o reverso do qual faz parte. Aliás, para Luhmann, toda observação é uma forma de diferenciar dois lados; ademais, estes se compõem pois, primeiramente, ambos lidam com a comunicação: a sociedade (e seus distintos subsistemas) é formada pela comunicação, e o direito nada mais é que uma comunicação especializada. Adicionalmente, o direito precisa supor a existência da sociedade - em termos sistêmicos, isto é explicado por meio do conceito de autopoiese, que permite a operação do direito a despeito da sua distinção da sociedade. ${ }^{39} \mathrm{O}$ direito produz e reproduz seus próprios elementos constitutivos a partir de um fechamento (ou clausura) operacional; o direito é autorreferente (direito é direito), ainda que esteja pressuposto $n a$ sociedade.

No entanto, esta explicação restará incompleta se não apontar que direito e sociedade devem ser capazes de se inter-relacionar - e a observação, aqui, recai na heterorreferência do direito. Na visão sistêmica, o direito não se encontra num isolamento solipsista; Luhmann não nega a sociedade em relação ao direito, pois há ruído de um pelo outro. $\mathrm{O}$ direito consegue, portanto, abrir-se para a sociedade (e vice-versa) sem que suas operações internas sejam comprometidas.

Contudo, as operações do sistema jurídico repercutem, em muitos casos, para além

\footnotetext{
${ }^{38}$ A proposta teórica de Niklas Luhmann pretendia superar uma crise da sociologia a partir da segunda metade do século XX, que oscilava entre trabalhos empíricos e releitura de clássicos, considerados ultrapassados e incompatíveis com a complexidade da sociedade. É neste sentido que esta tese compreende a transformação operada pela teoria dos sistemas abertos e fechados na história da sociologia. Veja VILLAS BÔAS FILHO, 2009, pp. 1-15.

${ }^{39}$ Vale lembrar a parábola dos camelos inicialmente contada por Heinz von Foerster e, depois, retomada em Luhmann. Seria necessário o empréstimo do décimo-segundo camelo para resolver o problema de partilha de onze camelos entre três beduínos? (LUHMANN, 2004). A parábola reforça a ideia de fechamento operativo e abertura cognitiva dos sistemas, pois o camelo é ao mesmo tempo necessário e não necessário para a partilha. Comentando a parábola explica De Giorgi: “o camelo realiza uma operação simbólica; ele constitui o fazer possível a operação; nele, a operação e resultado da operação, se confundem. E desta maneira a indizibilidade constitutiva do paradoxo constitutivo do direito encontra a possibilidade de decidir: o sistema a se bifurca e, através desta bifurcação, cada operação do sistema desparadoxiza o direito. A produção de direito é simultaneamente produção de não-direito" (2007, p. 32).
} 
do direito, pois, "[à] medida que o sistema do direito se utiliza da linguagem para comunicar, ele está sempre a comunicar possibilidades de associação fora do sistema jurídico" (ibidem, p. 75). Tais possibilidades nem sempre são plenamente controladas pelo direito, como quando um noticiário revela notícias de um crime, ou quando são exigidas forças policiais para garantir o cumprimento de decisões judiciais. Sublinha-se, novamente, as comunicações ultrapassam os filtros do direito, e nessas situações a operação das consequências ganha destaque.

Reitera-se que na visão sistêmica existe uma relação de simultaneidade e de coevolução entre direito e sociedade, assegurando tanto a dinamicidade quanto a existência dos sistemas, ainda que esteja operativamente limitada. Desta forma, é possível observar o tema das consequências extrajudiciais, a título de exemplo, por meio da questão da integração entre ambiente e sistema.

Operações com base nas consequências devem ser entendidas como internas do direito, exigindo, portanto, uma tradução e uma recepção mediadas pela comunicação jurídica mesmo que se observe uma simultaneidade no ambiente, caso se admita que isto também resulte em informação interna para outros sistemas funcionais. Campilongo aponta com clareza este desafio de promover traduções de comunicações, "quando um sistema interpreta o outro, aquilo que é interpretado não pode ser processado tal qual se encontra. Exigem-se "tradutores" ou "dicionários" que validem as interpretações de um sistema para o outro" (2012, p. 161).

A integração não é operada por meio da correspondência ponto a ponto entre sistema e ambiente, mas pressupõe que o sistema seja capaz de se abrir cognitivamente ao ambiente sem que se comprometa sua diferenciação funcional e suas operações internas. ${ }^{40}$ Ideias como acoplamento estrutural, interpenetração e canal de irritações e, inclusive, de organização como sistema de decisão ganham relevância a partir da teoria sistêmica para discutir a integração entre sistema (direito) e ambiente (sociedade).

Sem dúvida, o instrumental sistêmico oferece maior precisão descritiva dos sistemas sociais, uma vez que se ocupa em compreender de que maneira os sistemas autorreferenciais

\footnotetext{
${ }^{40} \mathrm{O}$ conceito de causalidade em Luhmann se transforma, pois, agora, trata-se de uma forma que depende de acoplamentos e fechamentos operativos ao mesmo tempo em que se produzem expectativas. Não se trata de simples possibilidade de atribuição de efeitos e causas, mas de observar atribuições bem-sucedidas. Para a discussão de causalidade, cf. LUHMANN, 1998 e 1982.
} 
descrevem-se, sem distorções e evitando uma apreensão subjetivista ou excessivamente formalista da sociedade. ${ }^{41}$ Todavia, esta tese evitará, na medida do possível, longas reconstruções e explicações de alguns conceitos da teoria dos sistemas sociais, exaustivamente abordados por importante literatura de divulgação da obra luhmanniana no Brasil. $^{42}$

Propõe-se, aqui, outra perspectiva - mais sintética e não tão ortodoxa - da teoria dos sistemas. Esta perspectiva, não menos coerente, é capaz de dialogar com uma literatura mais criativa e propositiva, que assume o compromisso de avançar e aplicar este instrumental no Brasil, "alargando o horizonte cognitivo" da teoria. ${ }^{43}$

${ }^{41}$ Além de assumir todo o instrumental da teoria dos sistemas, compartilha-se, nesta tese, da ideia dos processos de diferenciação funcional dos sistemas como traço de modernidade múltipla - o que evita a compreensão formalista de sociedade. Vale lembrar que apontar essas causas significa saber como o direito brasileiro opera, no sentido em que a diferenciação funcional do direito é uma forma de manifestação da sociabilidade na história (VESTING, 2015, p. 293). Além disso, a ideia de modernidade múltipla remete a Einsenstad (2000). O conceito evita pressupor uma homogeneização da modernidade, furtando-se a proceder a uma distinção absoluta entre o "centro" e a "periferia" do sistema social global. Admitem-se, aqui, outros processos seletivos de modernização, considerando-se as especificidades locais e históricas. É valioso o apontamento de Villas Bôas Filho: "[P] ara que se possa aplicar adequadamente a teoria dos sistemas à análise do direito na sociedade brasileira, é necessário que esta seja considerada uma forma seletiva entre outras e não a contrapartida negativa do modo pelo qual a mesma se realizou noutros contextos sociais" (2009, p. 295).

Ademais, vale lembrar que a distinção entre modernidade e pós-modernidade é produzida socialmente e o interesse na chave sistêmica é descrever como os outros descrevem o que outros descrevem, cf LUHMANN, 1995.

${ }^{42}$ Importante expoente da divulgação das ideias de Niklas Luhmann no Brasil foi Ferraz Jr., que afirmou que "[a] ideia de escrever sobre a função social da dogmática jurídica surgiu em face de uma indagação formulada pela teoria crítica desde o final da década de 1960, começo da de 1970. Naquela ocasião havia uma grande preocupação com relação aos temas do direito, principalmente os voltados para a perspectiva social; o exercício de certas funções do direito na sociedade. A preocupação com a dogmática jurídica, segundo as duas perspectivas até certo ponto opostas de [Theodor] Viehweg e [Niklas] Luhmann, acabou tomando forma, para mim, nessa indagação a respeito de como o direito funcionava em nossa sociedade e como ele, como objeto, desempenhava suas funções na vida social" (2010, p. 14). Sem dúvida, outro representante de renome foi Raffaele De Giorgi, que, além da participação em diversos cursos no Brasil, também formou uma geração de importantes professores que ampliaram a divulgação da visão sistêmica nas faculdades de direito na década de 1990, como Celso Fernandes Campilongo e Juliana Neuenschwander Magalhães. Vale ressaltar outros divulgadores da teoria no país, como Marcelo Neves, Leonel Severo Rocha e Willis Santiago Guerra Filho.

${ }^{43}$ A tese está mais interessada em dialogar com uma literatura mais criativa que permita alargar o horizonte cognitivo da teoria dos sistemas no Brasil. Cf., neste sentido, GONÇALVES, 2013a; VILLAS BÔAS FILHO, 2009 e 2015; ou DUTRA, 2016.Esta literatura é desdobramento de trabalhos dos anos 2000 que discutem a recepção de algumas ideias, questionando especialmente o caráter heterogêneo da sociedade mundial. Todavia, é possível fazer uma segunda distinção: na literatura criativa, alguns trabalhos apresentam-se como ampliação da Teoria dos Sistemas Sociais para observar a sociedade brasileira, mencionando-se a produção de professores e pesquisadores como LIMA (2015), AMATO (2017), FONSECA (2016), CORREIA (2014), ROSA (2014) entre outros.

Outra perspectiva defende o "uso em negativo" do referencial sistêmico para produzir os diagnósticos de época, ou até "usar Luhmann contra Luhmann", do que se deduz, portanto, serem trabalhos mais críticos do que propriamente receptivos à teoria dos sistemas. Alguns exemplos desta linha são MINHOTTO; GONÇALVES (2015) ou BACHUR; DUTRA (2013). Por fim, ressalva-se que a expansão e a recepção de Luhmann no Brasil 
Algumas razões justificam o desdobramento desta perspectiva pela tese. Primeiro, admitem-se novas condições na comunicação jurídica, sobretudo oriundas das transformações digitais, que implicaram novos modos operacionais das atividades judicantes e administrativas, e que, portanto, podem sugerir novos acoplamentos. ${ }^{44}$ Vale lembrar, ainda, que muitas observações apresentadas por Luhmann - falecido em 1998 - desconsideraram a revolução da comunicação operada pela rede mundial de computadores no início do século $\mathrm{XXI}$, sendo que o próprio sociólogo reconheceu ser necessário considerar as condições sociais a fim de compreender as transformações na informação (1995a, p. 457). ${ }^{45}$

Segundo, a tese aceita em parte as limitações apontadas pela visão crítica da teoria dos sistemas sociais, ${ }^{46}$ sobretudo diante da inexistência de uma teoria sistêmica da

restringiu-se quase completamente ao âmbito das faculdades de direito, carecendo, ainda, ser englobado por outras faculdades de ciências humanas. Acredita-se que esta limitação empobrece o debate das ideias sistêmicas e dificulta uma melhor compreensão da operação de outros sistemas sociais para além do direito no país.

${ }^{44}$ Nesse sentido diz VESTING (2015): “(...) [o sistema jurídico] depende em uma medida nunca antes vista de sobreposições, formas híbridas e acoplamentos estruturais com outros sistemas sociais, que, provavelmente, não mais podem ser facilmente apreendidas com a diferença (baseada no conceito de sentido) entre sistema e ambiente" (op. cit. p. 315).

45 No direito, o impacto revelou-se tanto quantitativamente quanto qualitativamente - acarretando, possivelmente, uma ressignificação da ideia de expectativas. Basta considerar, ilustrativamente, que no sítio eletrônico do Poder Judiciário de São Paulo milhões de decisões e atos são proferidos e disponibilizados pelos tribunais e juízes de primeiro grau. Segundo recente comunicado da Corregedoria-Geral da Justiça, na Primeira Instância da Justiça Estadual de São Paulo foram proferidas, entre $1^{\circ}$ de janeiro/2016 a 31 de dezembro/2016, 3.909.046 sentenças, cumpridas 847.840 cartas precatórias e realizadas 895.350 audiências. Cf. Comunicado CG n. ${ }^{\circ}$ 103/2017, disponibilizado em 06 de janeiro de 2017 - Diário da Justiça Eletrônico - Caderno Administrativo São Paulo, Ano X - Edição 2.282, p.4.

$46 \mathrm{O}$ ponto é de extrema importância, pois a tese intenta diversificar a apropriação brasileira de Niklas Luhmann. Na verdade, trata-se primeiramente de compreender que a abordagem luhmanniana ainda é uma forma eurocêntrica e desatualizada de observação (datada da década de 1990). Destaca-se a posição de Villas Bôas Filho ao propor uma redução da escala da observação para compreender os condicionamentos locais, cf. 2009, pp. 375-394. Segundo, acredita-se que a aplicação descritiva da teoria dos sistemas é capaz de identificar tensões e rupturas no plano das operações dos sistemas e, portanto, existe um latente potencial crítico nesta teoria, ao evidenciar os verdadeiros entraves internos ao sistema. No entanto, esta tese não pretende desenvolver uma leitura distinta de uso deste potencial, como o faria uma teoria crítica dos sistemas admitindo-a como um programa filosófico -, conforme ilustrado em um "uso em negativo da teoria do sistemas" (MINHOTO; GONÇALVES, 2015, p. 36) ou em "usar Luhmann contra Luhmann" (BACHUR; DUTRA 2013, p. 08). Minhoto e Gonçalves explicam o ponto do uso negativo como "um marcador de tendências de desdiferenciação funcional que se articulam à racionalidade econômica imperialista do neoliberalismo, em especial, à tendência para a formação de distintas 'indústrias' em diferentes âmbitos da vida social contemporânea” (MINHOTO; GONÇALVES, 2015, p. 23). Nesta visão admite-se uma aplicação prática da teoria dos sistemas, sobretudo ao refletir sobre o lado não marcado (unmarked space) dos sistemas sociais - e.g., ilícito, não ter, exclusão, perigo entre outros lados negativos dos códigos dos diferentes sistemas sociais. A reflexão sobre o lado não marcado possibilitaria observar os bloqueios e tensões que marcam a modernidade. Foi neste sentido, então, que Rudolf Wiethölter cunhou o termo Teoria Crítica dos Sistemas para fazer referência aos trabalhos desta literatura heterodoxa. Inclusive, Fischer-Lescano expressamente defendeu esta visão como um novo programa. Segundo este autor, "[d]e fato, há uma "teoria crítica dos sistemas". Essa 
argumentação jurídica na obra de Niklas Luhmann ou de uma sociologia da argumentação jurídica e dos tribunais. O campo da sociologia da argumentação é uma área pouco explorada nos programas de pós-graduação em direito e não consolidada no país, ainda que seja possível apontar trabalhos recentes que avançam neste campo - e.g., Campilongo (2012) e Lima (2015); ou mobilizando outro referencial Almeida (2016).

Em breve síntese, é possível dizer que esse ramo da sociologia jurídica preocupa-se em estudar a atuação dos tribunais $d a$ sociedade, abrangendo temas como modelos de trajetória do Estado e sua articulação com o Poder Judiciário, formas de organização e comunicação organizacional, formas de recrutamentos e gestão dos tribunais, discursos judiciais, processos de economização ou politização dos tribunais. Este campo de pesquisa pressupõe, portanto, uma teoria social ao mesmo tempo que se vale de embasamento empírico. $^{47}$

Por fim, a tese também encontra inspiração no desafio proposto em 1958 pelo historiador Fernand Braudel ao lançar a necessidade de se resgatar uma historiografia de longa duração que enfatize as continuidades e as raízes - aproximando história e sociologia - vis-à-vis uma narrativa marcada pela cronologia de eventos e de fôlego curto, própria de um "tempo do cronista e do jornalista" (1965, p. 264). ${ }^{48}$ No Brasil, nesse sentido, verifica-

teoria crítica dos sistemas pode filiar-se com os trabalhos da primeira geração de teóricos críticos da Teoria Crítica da Escola de Frankfurt que procura revelar o nexo entre as normatizações sistêmicas e a subjetividade" (2010, p. 164). Para uma visão geral da ideia de uma teoria crítica dos sistemas do direito, cf. ELMAUER, 2015.

Do ponto de vista sistêmico, diferente da Teoria Crítica, a critica é uma observação de segunda ordem que observa distinções, logo não há um programa subjacente a esta observação e, simultaneamente, não impossibilita a descrição dos paradoxos. Diz De Giorgi: “A crítica é uma observação que usa uma distinção. Mas o próprio sistema usa uma pluralidade de observações e, portanto, uma pluralidade de distinções” (2017, p. 270) e, ainda, o jurista italiano aproxima a ideia de crítica com a de redescrição operada pelos sistemas. A tese adota esta posição em relação à postura crítica da Teoria dos Sistemas.

47 Uma visão ortodoxa poderia rechaçar o potencial explicativo de pesquisas empíricas de sociedades complexas - o próprio Luhmann reconhece que os alcances dos métodos empíricos são limitados, devendose respeitar a autodescrição e auto-observação dos sistemas. À primeira vista, o alto grau de abstração desta teoria tornaria difícil articular uma pesquisa empírica. Acredita-se que as críticas de Luhmann estavam mais dirigidas aos fundamentos da pesquisa empírica positivista, vinculada à tradição lógico-ontológica, a qual parte da distinção ser/pensar, do que propriamente ao potencial empírico que o campo do construtivismo radical possibilita avançar. Vale dizer, se devidamente reformuladas as bases destas pesquisas, é possível admitir que pesquisas empíricas ajustem-se com o referencial da teoria dos sistemas, sendo que "[u]ma integração convincente daquelas pesquisas empíricas só seria realizável através da reintrodução do direito na sociologia jurídica, por meio de uma sociologia do direito levada a sério" (1983a, p. 12). Aliás, na introdução desta tese, já se apontou uma forma de controle da abstração da teoria por meio de um modelo de observação multinível.

${ }_{48}$ Este artigo, publicado na revista dos Annales, é um marco do debate historiográfico, em especial porque Braudel responde a um texto de Lévi-Strauss, "História e etnologia", de 1949 - futuramente publicado como 
se nas décadas de 1940 e 1950 o avanço do gênero ensaístico da "formação" predominante nas ciências sociais, ${ }^{49}$ que se valia do direito como elemento explicativo de uma interpretação para discutir o pensamento social brasileiro, acompanhado ou não pela reflexão da construção nacional. ${ }^{50}$

Apoiada neste "novo" relato histórico, ou de uma história conjectural, observa-se as operações dos tribunais da sociedade brasileira considerando as permanências e a trajetória desta organização social no começo do século XXI. A longa duração de Braudel ou o gênero da "formação" apresentam-se, assim, como complemento de fundo para a descrição sistêmica. Admite-se que a observação de sistemas diferenciados funcionalmente seja um modelo que também não escapa do tempo da história das ideias.

Vale dizer, a observação é condicionada temporalmente - há um tempo como experiência da observação científica (tempo do observador) que deve ser considerado e diferenciado em relação à sociedade (tempo da observação), ainda que ambas estejam entremeadas como comunicação a partir do desenvolvimento da pesquisa. ${ }^{51}$

Luhmann já sustentava que "[a] ciência se diferencia da e na sociedade e encontra as causas disso em si mesma. Todavia, não poderia fazer isto, se fosse socioestruturalmente impossível de realizar as correspondentes diferenciações no processo de comunicação" (1996, p. 429, tradução livre). Simultaneamente, a distinção entre direito e sociedade pela

capítulo do livro Antropologia estrutural. Segundo Rodrigues (2009), os dois principais pontos que o texto combate são o modelo de interdisciplinaridade, de reação aos saberes tradicionais e estanque, e a visão do historiador como aquele que buscava entender o tempo curto - da revolução ou das ações individuais. Este texto é importante, ainda, para uma reconstituição do debate e dos desdobramentos para a historiografia. Braudel aponta para a necessidade da compreensão de uma espessura da história, sobre a qual é possível a reflexão crítica conforme produzida pelos historiadores do século XVIII e do início do XIX, que aceitaram o fato de " $(. .$.$) que ir além do tempo curto foi o bem mais precioso, porque o mais raro, da historiografia dos cem$ últimos anos, compreenderemos o papel eminente da história das instituições, das religiões, das civilizações, e graças à arqueologia, a qual são necessário vastos espaços cronológicos, o papel de vanguarda dos estudos consagrados à Antiguidade clássica" (1965, p. 266).

49 O gênero "formação" é caracterizado pelos filósofos Arantes e Arantes (1997) como uma grande narrativa capaz de produzir certo sentido para a história brasileira, de "dotar o meio gelatinoso de uma ossatura moderna que lhe sustente a evolução". Essas interpretações sobre o Brasil focaram-se na passagem da colônia para a nação, seguindo "na direção do ideal europeu de civilização relativamente integrada — ponto de fuga de todo espírito brasileiro bem formulado" (op. cit., p. 12).

${ }_{50}$ É possível considerar como exemplos as obras Formação do Brasil Contemporâneo de Caio Prado Jr., Formação Econômica do Brasil de Celso Furtado e Formação da Literatura Brasileira de Antonio Candido. Para uma discussão geral da ideia de formação, cf. ARANTES; ARANTES, 1997.

${ }^{51}$ Veja a abordagem de ANGELELLI (2017), que aproxima a pesquisa histórica da pesquisa sociológica a partir da historicidade - relacionando Luhmann e Koselleck -, diz: “ a pesquisa histórica não é atemporal, assim como não é atemporal o seu objeto de análise. A desconsideração da historicidade da própria observação histórica é inaceitável na sociedade moderna" (op. cit., p. 18). O pesquisador também afirma na sequência: "é necessário que a abordagem histórica tenha consciência não apenas da sua historicidade e da sua condição moderna, mas também da de seu objeto de estudo" (ibidem, p. 148). 
observação da ciência permite a abertura da pesquisa sociológica para as grandes perspectivas, como De Giorgi exemplifica: “[a sociologia] não copia aquilo que o direito usa como realidade, não copia a semântica jurídica e suas distinções, mas observa o que tal semântica não pode descrever, revela aquilo que não pode ser visto" (2016, p. 116).

Diante destes apontamentos, o leitor deve compreender a importância das mudanças de estilo da leitura sistêmica dos tribunais e da sociedade brasileira feitas nesta tese e familiarizar-se com um tempo mais lento de compreensão do próprio sistema científico. Muito mais do que respostas ou propostas normativas, esta tese traz uma reflexão sobre a trajetória da sociedade brasileira em relação às operações dos tribunais, em especial a partir da problematização de algumas observações sobre as consequências do direito $d a$ e $n a$ sociedade. 


\section{CONSIDERAÇÕES FINAIS}

Discutiu-se, nesta tese, a partir do referencial teórico de Luhmann o argumento consequencialista do direito na sociedade brasileira, enquanto especificação do sistema social global. Antes de apresentar soluções, modelos e propostas, o processo consistiu em distinguir e compreender como estes argumentos operam no direito e na sociedade, indicando as tensões e as exigências da argumentação diante do primado da diferenciação funcional. Simultaneamente, observou-se como estes argumentos também são parte e produto das operações das organizações, o que possibilita variação no interior dos sistemas.

Para tanto, recorreu-se ao modelo multinível de observação, que permitiu a articulação de três posições complementares de observação distintas e, inclusive, a redução de abstração do referencial. O percurso incluiu, nesta ordem, uma observação do nível teórico para o nível da sociedade e, depois, para o nível organizacional. Nestas considerações finais será reconstituído este caminho, sublinhando-se as ideias mais importantes alcançadas em cada etapa.

$\mathrm{Na}$ parte I, foram esmiuçadas as transformações internas da teoria do direito nas últimas décadas, destacando-se como ponto central a diferenciação entre uma teoria do direito e uma teoria da argumentação jurídica, que marcou uma distinção semântica entre o tratamento do consequencialismo e o do argumento consequencialista pelo direito. Esta distinção marca uma forma de variação interna pelo sistema. Notou-se, então, que o consequencialismo está mais próximo de teorias fisicalistas do direito, sobretudo daquelas da primeira metade do século XX, e também das teorias externas do direito, em especial o movimento da AED.

Nesta ocasião, o consequencialismo foi caracterizado como uma aplicação direta de razões extrajurídicas para a tomada de decisão que não se atenta às formas de adequação, de programação e, sobretudo, de codificação do direito. Afirmou-se que, em grande medida, isto ocorre pela insuficiência de programas no nível operacional e pela ausência das teorias da argumentação jurídica no nível reflexivo do direito.

A passagem e a diferenciação dos argumentos consequencialistas foram abordadas, posteriormente, a partir de teorias da argumentação - ponto enaltecido pelas escolas realistas do direito, que marcaram, aliás, um movimento de transição, pois, de um lado, sustentavam a superação das teorias fisicalistas ao indicarem a incompletude ou o esvaziamento do papel 
do argumento do direito, mas, por outro, não foram capazes de particularizar internamente o consequencialismo.

Foram retomados importantes teóricos da argumentação jurídica, em especial MacCormick, Bańkowski e Feteris, responsáveis por efetivamente distinguir o consequencialismo do argumento consequencialista e levar adiante modelos de argumentação consistentes pelo direito. Em oposição a uma visão hartiana, nestes modelos as decisões difíceis, i.e., que estabelecem um sentido não evidente à regra, não determinam uma atuação fora do direito; ao contrário, a argumentação jurídica oferece uma variedade de informações para fundamentar as decisões.

Assim, nesta tese, o argumento consequencialista do direito significa a possibilidade de se considerar possíveis consequências de uma decisão jurídica como razão para decidir. Não se nega, ademais, que a incorporação dessas consequências na comunicação jurídica provocou, de um lado, uma grande incerteza programatória, e, do outro, a dependência de uma visão substancialista no direito, uma vez que a mobilização destes argumentos implica, muitas vezes, o uso de ferramentas empíricas para avaliação.

Defendeu-se, ainda, que Luhmann oferece uma maneira privilegiada de verificar esta diferenciação e estes desdobramentos, sobretudo ao se esclarecer o tratamento dispensado ao tema da argumentação jurídica antes e depois do giro autopoiético no interior da sua obra. Sublinhou-se também que, ao recorrer a paradoxos, a visão sistêmica evita a polarização e descrições simplistas e, ao mesmo tempo, admite a necessidade de se produzir observações de segunda ordem, i.e., análises sobre como a observação do observador acontece.

Num primeiro momento, especialmente preocupado em observar a dogmática jurídica, o sociólogo alertou para os problemas do consequencialismo diante da crescente exigência temporal orientada para o futuro sofrida pelo direito. Depois do giro autopoiético na sua obra, quando consegue definir com clareza a distinção e a relação entre sistema/ambiente, Luhmann passa a dedicar especial atenção aos argumentos jurídicos.

Argumentos são apresentados como formas com duas faces: de um lado, confirmam a redundância; do outro, possibilitam a variedade de informação. Entre redundância e variedade, a argumentação sempre se vê numa situação de observação de segunda ordem, que reflete as oportunidades de aplicação e justificação dos programas à luz do caso concreto, permitindo, inclusive, que sejam reverberadas possibilidades que ali não estão cristalizadas ou enfrentadas as justificativas subjacentes aos argumentos - i.e., observações de terceira ordem. 
As consequências passam, portanto, a ser consideradas pelo direito como argumentos jurídicos, mas simultaneamente permitem a reflexão sobre como o direito relaciona-se com o ambiente, mormente a partir de metacódigos da sociedade, como sugerido nesta tese com as formas "risco/perigo", "inclusão/exclusão" e "crise/estabilização".

Na segunda fase luhmanniana (pós-giro autopoiético), por assim dizer, depreende-se que o direito oferece múltiplas instâncias de reflexão sobre seus limites e possibilidades. Neste sentido, destacou-se e defendeu-se a importância do desdobramento de um campo de pesquisa específico, como a sociologia da argumentação jurídica. Nesta perspectiva, programas jurídicos são constituídos em condições plurais, envolvendo tanto mecanismos centrais - como as cortes e o exercício dos poderes políticos - quanto instrumentos que extrapolam as fronteiras dos Estados - como organizações não estatais, corporações e movimentos sociais. Ademais, não se pode perder de vista a operação de um ambiente interno do direito, que é altamente complexo - tal como o externo - que possibilita novas comunicações.

$\mathrm{Na}$ parte II, analisou-se como a atual sociedade mundial opera a partir de conceitos que repercutem a dificuldade de lidar com o futuro, observando-se, por relevante, que o aumento do argumento consequencialista no direito também reflete esta dificuldade quando verificadas transformações na sociedade enquanto ambiente. Na chave sistêmica, a sociedade depende cada vez mais de decisões sobre o futuro e das atuações dos experts para lidar com as consequências - i.e., sugeriu-se a ideia de controle pelas consequências.

Reforçam esta transformação o avanço da tecnologia e as modificações na comunicação, presentes na sociedade mundial. Em acréscimo, foram introduzidos e explicados os conceitos sistêmicos de "risco/perigo", de “inclusão/exclusão" e de “crise/estabilização" com o intuito de debater e contextualizar a aplicação dos argumentos consequencialistas do direito na sociedade brasileira, caracterizada como uma especificação da sociedade mundial.

Esta perspectiva da sociedade mundial foi relacionada à ideia de economização. Não se compartilha, aqui, da leitura de que há uma colonização do código econômico sobre os demais - em verdade, o interesse reside em entender como o risco econômico repercute em outros sistemas sociais, sobretudo como perigo ambiental e irritação, quando se observam estruturas de acoplamento ou atuação das organizações sociais. A economização, nestes termos, ligada à dupla circulação (i.e., capacidade/incapacidade de pagar), é um alto influxo comunicacional da economia que produz efeitos colaterais, uma vez que riscos econômicos 
não são desdobrados somente em operações centrais do sistema econômico, mas também pelo direito ou por políticas econômicas. Estes desdobramentos são observados por cada sistema, de modo geral, como uma comunicação global e de forma comparada.

Neste diapasão, questionou-se também o incremento da demanda pela atuação de experts fora do sistema científico, porque estes, em tese, saberiam lidar melhor com as consequências. Ainda que se tenha observado a valorização destes profissionais da ciência, percebeu-se que sua atuação no interior do sistema jurídico ou do político revelou lacunas das respostas científicas para fornecer soluções para a tomada de decisão de outros sistemas sociais. A ciência possui uma temporalidade própria, específica, relacionada ao processo de investigação, bem como função e código distintos que precisam ser observados à luz do primado da diferenciação funcional.

No Brasil, estas mudanças ficaram mais evidentes durante o final do século XX e início do XXI, em conexão com um período que marcou o fim de um ciclo da redemocratização. A tese observou os seguintes condicionamentos locais: no plano econômico, destacou-se o Plano Real; no jurídico, a promulgação da Constituição Federal de 1988 e a Reforma do Judiciário; no âmbito político, a reforma gerencial da Administração Pública e a ausência de uma reforma eleitoral.

Neste contexto, os direitos sociais e econômicos ganharam destaque no país, já que passaram a desempenhar um importante papel dentro do sistema jurídico, i.e., permitiram à sociedade exigir que a ordem econômica fosse colocada à sua disposição a fim de cumprir as mais diversas realizações sociais e, ao mesmo tempo, revelou-se uma intersecção entre direito e as pressões ambientais advindas da economização e do conhecimento científico.

$\mathrm{Na}$ parte III, enfatizou-se o debate sobre direitos sociais e econômicos a partir das operações dos tribunais enquanto organizações sociais e não vinculados exclusivamente a um sistema de função. Para tanto, procedeu-se à investigação de como acontece a adjudicação desses direitos, o que exigiu compreender a diferença das atuações dos tribunais dentro e fora do direito.

Sustentou-se, aqui, que cortes têm chamado para si a tarefa de se relacionar com organizações externas ao sistema jurídico, fazendo uso, para tanto, da diversidade da comunicação organizacional muitas vezes baseada em técnicas e critérios não jurídicos.

Tribunais podem ser observados como centros do sistema jurídico ou como organizações periféricas de outros sistemas sociais. Devem atentar-se aos limites de cada subsistema e ao desdobramento dos paradoxos das suas comunicações organizacionais, para 
evitar um bloqueio estrutural das suas atuações na sociedade, sobretudo quando argumentos consequencialistas estão em juízo.

Nesta parte da tese foi estabelecida uma tipologia para análise dos tribunais na sociedade a partir da comunicação produzida por suas operações, a saber: tribunal judicial original; tribunal administrativo deferencial; tribunal arbitral consequencial e tribunal constitucional catalisador. Não se sustentou, contudo, um padrão normativo adequado entre os tipos; as ilustrações pretenderam traçar e marcar observações, destacando o aspecto funcional de tribunais diferentes na sociedade complexa.

A partir destes pressupostos sociológicos e desta tipologia examinou-se, na parte final da tese, a atuação do STF após a promulgação da CF/88 num recorte material de adjudicação de direitos econômicos em sede de controle concentrado de constitucionalidade. Isto porque em alguns casos desta matéria, esta Corte vinha considerando argumentos consequencialistas para a tomada de decisão.

Enquanto Corte constitucional, o STF consolidou-se como instância legítima para arbitrar interesses de minorias e para decidir conflitos institucionais e políticos no país. Não há dúvidas de que no atual desenho institucional, a Corte desempenha um papel relevante no delineamento e no controle das políticas públicas e contribui para a criação de incentivos e desincentivos para as mais variadas atividades.

Sustentou-se, portanto, que este tribunal apresenta-se como um locus privilegiado de captação das sensibilidades advindas do ambiente do direito brasileiro. Notadamente o político - ao debater a Constituição - e o econômico - ao interpretar contratos e formas societárias. Por isso, a análise das decisões deste tribunal que opera seletivamente de maneira autorreferente (consistente juridicamente) e também heterorreferente (por reduzir e tratar a complexidade do ambiente) indicou como argumentos consequencialistas estão sendo mobilizados pelos ministros ao julgarem casos concretos.

Produziu-se, nesta tese, banco de dados, incluído como anexo. Foram coletadas, sistematizadas e analisadas 252 decisões, cujos dados revelaram que o impacto das decisões em sede de controle concentrado é considerado pelos ministros. Justifica-se a cautela adicional dos ministros neste controle, pois sabem que, ao considerarem consequências não jurídicas como razões para decidir, os efeitos de suas escolhas podem reverberar em outras autoridades.

Assim, observou-se que ministros preferem evitar avaliações amplas e técnicas, que extrapolem o conhecimento da Corte. Todavia, isto não significa que o tribunal não o faça: 
dentro do recorte, verificou-se que nos casos de controle concentrado, ministros tenderam a considerar, ainda que com dificuldade em relação aos métodos, consequências extrajurídicas em seus votos.

Do ponto de vista sistêmico, tal achado reitera as ideias da parte I da tese que indicaram a necessidade do direito brasileiro produzir uma distinção entre consequencialismo e argumento consequencialista, além do desafio de consolidar uma dogmática jurídica forte no sentido de ser capaz, simultaneamente, de selecionar e enfrentar este tipo de argumento e de controlar as consistências das decisões.

Do lado não marcado desta observação - seguindo o referencial sistêmico -, vale destacar que a descrição da prática adjudicatória pode, em algumas circunstâncias, ser admitida como um "cheque em branco". É o caso de observar os perigos do consequencialismo no direito, em especial quando determinados litigantes ou autoridades se aproveitam de certo esgarçamento da dogmática jurídica brasileira para fazer valer expectativas não preestabelecidas pelo direito - o que a tese relaciona com a ideia do déficit de filtragem.

Na prática, nos casos examinados, como desdobramento da ideia do déficit de filtragem, os textos legais e a jurisprudência acabaram limitando os ministros, que deixaram de considerar fatores que não fossem filtrados pelo sistema jurídico - o que também justificou o elevado número obtido de julgados improcedentes e negado seguimento. Corrobora-se, a partir destas informações, uma atuação subótima do STF, porque mesmo quando a Corte acredita que uma posição consequencial pode gerar um resultado melhor, ou socialmente mais desejado, prevalece uma preocupação maior com as operações internas do sistema jurídico.

Em contrapartida, esta subotimização da atuação do STF sugere e explica o surgimento e a ampliação de outros centros de tomada de decisão no Brasil, notadamente a partir da década de 1990. Trata-se, aqui, de correlacionar sua atuação com a expansão dos tribunais arbitrais e dos tribunais administrativos e de insinuar, em alguma medida, uma "fuga do direito" dos tribunais originais para outros tipos de tribunais - reflexo de uma evolução do direito, associada às transformações globais explicitadas na parte II.

Não se sustentou também que a ampliação da atuação desta Corte para outros sistemas sociais implicou a substituição às demais organizações político-representativas, nem às econômicas ou, ainda, como forma de correção de qualquer problema social. Ao contrário, observou-se os limites do direito e a preocupação com tais limites nos votos dos 
ministros, mesmo diante do déficit de filtragem e da variedade produzida via argumentação em juízo.

O que se enfatizou ao longo da tese, em diferentes posições de observação, foi que a comunicação produzida pelo STF (e por qualquer outro tribunal) pode tanto gerar novo valor informativo dentro do sistema jurídico, como também pode circular para além dele. Portanto, o papel desempenhado pelo tribunal deve ser compreendido à luz da complexidade dos processos da sociedade mundial e a partir de uma constelação de outros tribunais que o circunda.

Por fim, retoma-se, agora, um ponto subjacente às três posições de observação apresentadas na tese, o problema dos futuros contingentes, sobretudo em relação à operação do direito. Do ponto de vista sistêmico e como visto nesta tese, a referência ao tempo é uma maneira que multiplica todos os problemas. ${ }^{525}$

Considerando-se a dimensão temporal dos sistemas, a contingência apresenta-se como a dificuldade de antecipação do futuro diante do presente - isto não significa, porém, que o direito não possa desfuturizar e operar com o futuro hoje, imaginando e produzindo prognósticos. Restou evidenciado, nesta tese, que a argumentação consequencialista do direito é, na verdade, uma operação sobre o presente futuro, ainda que ocorra de forma utópica e problemática diante da falta de programas e das limitações operacionais.

A operação sobre o presente futuro é compreendida a partir da dificuldade de se observar simultaneamente o factual e o contrafactual. ${ }^{526}$ Este é o questionamento de fundo, e.g., acerca da alegação de que uma decisão em favor de poupadores em ações, que discutem a correção de índices econômicos em face dos bancos, provocaria uma quebra do sistema financeiro. Qual seria o real motivo desta quebra, o não provisionamento de recursos por parte das instituições? Da mesma forma, invoca-se um crescimento da taxa de judicialização no Brasil após a promulgação da $\mathrm{CF} / 88$. Teria sido porque a $\mathrm{CF} / 88$ facilitou o acesso à justiça?

\footnotetext{
${ }^{525}$ Cf LUHMANN, 1995a, pp. 41-52.

${ }^{526}$ A observação simultânea do factual e do contrafactual permite distinguir causalidade de correlação, porque dois fenômenos correlacionados não necessariamente implicam uma relação de causalidade. Assim, explicar por que algo aconteceu gera forçosamente uma explicação de por que outra coisa não aconteceu. Weber (2001) já tinha indicado que declarações causais envolvem obrigatoriamente proposições contrafactuais, geralmente implícitas. É nesse sentido que o pensamento contrafactual tornou-se objeto relevante para as ciências sociais, para além de suas aplicações em áreas biológicas e exatas.
} 
É impossível ter certeza dessas afirmações. Em verdade, uma declaração de verdade só poderia ser dada se tivesse sido possível também observar a taxa de judicialização caso a $\mathrm{CF} / 88$ não tivesse sido promulgada, ou qual teria sido o resultado para os poupadores se a Corte tivesse decidido em favor dos bancos. Percebe-se, portanto, que no sistema jurídico é difícil observar o futuro e, inclusive, para a tomada de decisão é laborioso lidar com o contrafactual. $^{527}$

Em suma, as consequências tratadas ao longo desta tese reforçam uma atenção diferente. Ao contrário, da perspectiva do controle pelas consequências, adotou-se uma posição mais cautelosa em relação às consequências e mais respeitosa em relação ao futuro do direito. Evitou-se afirmar que o futuro é previsível e controlável pelas tecnologias, aí incluída a dogmática jurídica.

A história das sociedades, e a do direito inclusa, está repleta de exemplos que contrariam acontecimentos passados e que não foram previstos. Os apontamentos desdobrados nesta tese reforçam o tratamento das consequências de forma diferenciada, pois o direito, agora, corresponde às alterações da comunicação social, mas é produto também de sua história.

Para a sociologia jurídica, então, o interesse reside em observar quais e como as consequências - e.g., o futuro - são tratadas pelo direito. Conforme demonstrou esta tese, baseada no pensamento de Luhmann, o principal papel do sociólogo do direito é observar as operações, programações e relações estabelecidas pelo sistema jurídico e suas organizações, distinguindo-se da sociedade. Simultaneamente, o sociólogo também observa aquilo que o direito não consegue descrever, ou como De Giorgi afirma "nomeia o que não pode ser nominado" (2016, p. 116), revelando os paradoxos constitutivos do direito.

\footnotetext{
527 A contrafactualidade é importante para a pesquisa em direito porque permite conjecturar sobre as possibilidades elucidativas e testar as hipóteses. Sua consideração na formulação de hipóteses permite melhor compreender e controlar a contingência pela pesquisa — não só as possibilidades tornam-se visíveis como as explicações causais de como e por que o direito tomou sua forma atual fortalecem-se. A fim de evitar o viés de retrospectiva, respostas simplistas e trabalhar com cenários contrafactuais, muitas pesquisas empíricas recorrem a instrumentais estatísticos (amostragem, correlação, regressão, entre outros). Um dos principais desafios no manejo da estatística em direito é a necessidade de produzir aproximações críveis — vale lembrar que a regra de ouro para o pesquisador, familiarizado a procedimentos científicos, é justamente inferir a causalidade comparando conjuntos de unidades que recebem tratamentos diferentes por meio de experimentos controlados. Citem-se, como exemplos, os tantos experimentos químicos que alteram a composição de determinada solução, procedendo-se à comparação entre a solubilidade em água de ácidos e a não solubilidade das bases, além de muitos outros experimentos da física, da biologia, da medicina etc. Para uma discussão deste ponto, veja capítulo 7 da tese.
} 
Retoma-se, finalmente, o mito grego de Cassandra e Heleno narrada por Homero em Ilíada (2005), poema supostamente escrito em 700 a.C. que aborda o desfecho da Guerra de Troia, para iluminar os paradoxos do direito e da sociedade em relação ao futuro discutidos nesta tese.

Estes personagens simbolizam, ao mesmo tempo, a sedução pela capacidade reflexiva de antecipar situações - próprio dos heróis homéricos - e a aversão pela incapacidade prática de lidar com essas situações antecipadas - traço que também reflete as debilidades desta sociedade à qual pertencem estes heróis.

Trata-se de marcar um paradoxo, que simboliza a oscilação entre divindade e humanidade ${ }^{528}$ e que, também, está presente em outras distinções desdobradas e exploradas nesta tese: presente futuro/futuro presente; utopia/tecnologia; perigo/risco; consequencialismo/argumento consequencialista; sociedade/direito etc.

O mito aborda a trajetória da heroína Cassandra, filha dos reis de Troia, Príamo e Hécuba. Cassandra é uma profetisa, possui a capacidade de antecipar e prever o futuro dom que também compartilha com seu irmão gêmeo Heleno, já que ambos foram dotados desta capacidade pela divindade ainda quando crianças, após adormecerem no Templo de Apolo.

Diferente da trajetória de Heleno, Cassandra, jovem de grande beleza, foi condenada e amaldiçoada pelo deus Apolo, depois de negar-lhe seu amor. A maldição lançada foi que ninguém iria acreditar nas suas previsões, nem mesmo sua família.

É relevante perceber neste mito como o dom e a maldição carregam o destino da cidade e da família, sobretudo diante da descrença das previsões de Cassandra e das consequências indesejadas reveladas aos inimigos dos troianos por Heleno.

De um lado, não levando a sério as consequências pelos troianos, Cassandra já tinha alertado seus pais, reis de Troia, e seus demais irmãos guerreiros sobre os futuros ataques militares dos argivos (gregos), inclusive sobre o artifício do cavalo de madeira (cavalo de Troia) que permitiu a entrada dos inimigos e o ataque surpresa à noite.

\footnotetext{
528 Este paradoxo está presente nas análises de Werner Jaeger sobre a formação do homem grego, quando analisa o poema: "Os heróis da Ilíada, que se revelam no seu gosto pela guerra e na sua espiração à honra como autênticos representantes da sua classe, são, todavia, quanto ao resto da sua conduta, acima de tudo, grandes senhores, com todas as suas excelências, mas também como todas as suas imprescindíveis debilidades. É impossível imaginá-los vivendo em paz: pertencem ao campo de batalha. Fora dele só os vemos nas pausas do combate, nas suas refeições, nos seus sacríficos, nos seus conselhos" (2003, p. 41).
} 
Do outro, apostando nas consequências pelos argivos, Heleno - que tinhas suas profecias confiadas - foi capturado pelas tropas inimigas e torturado a fim de que revelasse como os argivos poderiam atacar Troia. Segundo a história, o saldo foi a destruição da cidade, além da morte de parte da família de Cassandra e Heleno.

Para o testemunho de sua obra, Homero indicou as sutilezas de distinguir e operar com as consequências na sociedade antiga. Dentre as muitas interpretações do mito de Cassandra e Heleno, no contexto desta tese, a mais interessante é indicar como é difícil levar as consequências a sério, sobretudo quando se discute o futuro, pois, dependendo das especificações de cada sistema, pode-se tanto operar efeitos desejados como desdobrar no oposto, vinculado à descrença, mentira e destruição - posição que ficou consagrada na psicologia pela expressão "síndrome de Cassandra".

Não tão distante do caráter simbólico deste mito, hoje, diversos cavalos de Troia, como malware, estão espalhados na comunicação digital. Para a construção de uma sociologia interessada em observar o futuro da sociedade mundial funcionalmente diferenciada, no caso desta tese relacionada às operações do direito, a síndrome deve ser relativizada - nem tanto à Cassandra, nem tanto ao Heleno.

O que importa é observar o modo como a sociedade e os subsistemas veem-se a partir dos seus respectivos entendimentos, compreendendo suas permanências e rupturas sem excluírem-se mutuamente. 


\section{REFERÊNCIAS BIBLIOGRÁFICAS}

A tese incluiu nestas referências bibliográficas o ano da edição utilizada e na sequência, quando possível, entre colchetes, o ano original da edição da obra ou da primeira publicação em periódico.

ACKERMAN, Bruce. Nós, o Povo Soberano: Fundamentos do Direito Constitucional, trad. Mauro Raposo de Mello. Belo Horizonte: Del Rey, 2006 [1991].

ALMEIDA, Frederico de. Os juristas e a política no Brasil: permanências, deslocamentos e reposicionamentos. Lua Nova, v. 1, 2016, pp. 213-250.

AMATO, Lucas Fucci. Imaginação constitucional: direitos humanos, cultura e desenvolvimento em Luhmann e Unger. 2017. 419 f. Tese (Doutorado em Direito) - Faculdade de Direito, Universidade de São Paulo, São Paulo, 2017.

AMSDEN, Alice. The Rise of "The Rest": Challenges to the West from LateIndustrializing Economies. Oxford: Oxford University Press, 2001.

ANGELELLI, Gustavo. História do direito: tempos do sistema jurídico. Curitiba: Juruá, 2017.

ARANTES, Otília Beatriz Fiori; ARANTES, Paulo Eduardo. Sentido da formação: Três estudos sobre Antônio Cândido, Gilda de Mello e Souza e Lúcio Costa. São Paulo: Paz e Terra, 1997.

ARANTES, Rogério. Judiciário e Política no Brasil. São Paulo: Editora Sumaré, 1997.

ARAÚJO, Inês Lacerda. O pragmatismo pode ser identificado com o utilitarismo? $\mathbf{1 2}^{\mathbf{0}}$ Encontro Internacional sobre Pragmatismo. São Paulo: Centro de Estudos do Pragmatismo, v. 1. 2009, pp. 34-35. Disponível em: $<$ http://www.gtpragmatismo.com.br/redescricoes/redescricoes/memoria/ines.pd f>. Acesso em 12 jan. de 2016.

ARAÚJO, Thiago Cardoso. Análise Econômica do Direito no Brasil: Uma leitura à luz da Teoria dos Sistemas. Rio de Janeiro: Lumen Juris, 2016.

ARGUELHES, Diego Werneck. Poder Não é Querer: preferências restritivas e redesenho institucional no Supremo Tribunal Federal pós-democratização. Universitas/Jus, v. 25, 2014, pp. 25-45. 
ARGUELHES, Diego Werneck. Deuses pragmáticos, mortais consequencialistas: a justificação consequencialista de decisões judiciais. 2006. 220f. Dissertação (Mestrado em Direito Público) - Faculdade de Direito, Universidade do Estado do Rio de Janeiro, Rio de Janeiro, 2006.

Argumentação Consequencialista e Estado de Direito: Subsídios para uma compatibilização. Anais do XIV Encontro Nacional do CONPEDI. Florianópolis: Fundação Boiteaux, 2005, pp.01-20.

ARGUELHES, Diego Werneck; RIBEIRO, Leandro Molhano. Criatura e/ou criador: transformações do Supremo Tribunal Federal sob a Constituição de 1988. Revista Direito GV, v. 12, n. 2, 2016, pp. 405-440.

ARIDA, Pérsio et al. Credit, interest, and jurisdictional uncertainty: conjectures on the case of Brazil. In: GIAVAZZI, F. et al. Inflation Targeting, Debt, and the Brazilian Experience, 1999 to 2003. Cambridge, MA:MIT Press, 2005.

ARISTÓTELES. Da Interpretação, trad. José Veríssimo Teixeira da Mata. São Paulo: Editora Unesp, 2013.

ARRUDA, Thais Nunes. Direito e objetividade: a viabilidade do projeto de naturalização da teoria do direito de Brian Leiter. 2015. 391 f. Tese (Doutorado em Direito) Faculdade de Direito, Universidade de São Paulo, São Paulo 2015.

ASSOCIAÇÃO DE MAGISTRADOS BRASILEIROS. Magistrados Brasileiros: caracterização e opiniões. 2015. Disponível em: < http://www.amb.com.br/wpcontent/uploads/2015/12/Pesquisa-PDF.pdf>. Acesso em 30 nov. 2016.

Magistrados Brasileiros: caracterização e opiniões. 2005. Disponível em: $<$ http://www.amb.com.br/portal/docs/pesquisa/PesquisaAMB2005.pdf $>$. Acesso em 30 nov. 2016.

AYER, Alfred Jules. The origins of pragmatism. Glasgow: Macmillan, 1968.

BACHELARD, Gaston. A formação do espírito científico: contribuição para uma psicanálise do conhecimento, trad. Estela dos Santos Abreu. Rio de Janeiro: Ed. Contraponto, 2005 [1943].

BACHUR, João Paulo; DUTRA, Roberto (Orgs.). Dossiê Niklas Luhmann. Belo Horizonte: UFMG, 2013.

BAECKER, Dirk. Prefacio a la edición española. In: LUHMANN, Niklas. La economía de la sociedade, trad. Aldo Mascareño. Mexico: Herder, 2017, pp. 55-69. 
BAECKER, Dirk. The Culture Form of Crisis. In: TEUBNER, Gunther; FEBBRAJO, Alberto; KJAER, Poul. The financial crisis in constitutional perspective: the dark side of functional differentiation. Oxford: Hart Publishing, 2011, pp.173180.

. The Form of the Firm. Organization: The Critical Journal on Organization, Theory and Society, Vol. 13, 2006, pp. 109-142.

BAŃKOWSKI, Zenon. Vivendo plenamente a lei. Rio de Janeiro: Elsevier, 2007 [2001].

. How Does It Feel To Be On Your Own? The Person in the Sight of Autopoiesis. Ratio Juris, 1994, pp 254-266.

BARBOSA, Samuel Rodrigues. Constituição, democracia e indeterminação social do direito. Novos Estudos Cebrap, v. 96, 2013, pp. 33-46.

BARROS, Marco Antonio Loschiavo Leme de. Constitutional design and the Brazilian judicial review: remarks about strong and weak-form review in the Brazilian Federal Supreme Court. Revista Opinião Jurídica, 2017, pp. 180-206.

. Consequencialismo e o argumento econômico em juízo: estudo sobre a utilização do argumento do risco sistêmico dos planos econômicos na ADPF 165. Revista do Mestrado em Direito UCB, v. 8, 2014a, pp. 1-24.

- Segurança jurídica extrajudicial e precedentes administrativos: uma investigação sobre a aplicação de precedentes do Cade a partir da análise dos mapas de citação. 2014. 120 f. Dissertação (Mestrado em Direito e Desenvolvimento) - Escola de Direito de São Paulo da Fundação Getulio Vargas, São Paulo. 2014b.

; BASTOS, Marina Montes. O discurso jurídico das cortes brasileiras e a preocupação com a clareza: um estudo acerca do uso dos termos jurídicos. Direito e Democracia (ULBRA), v. 14, 2013, pp. 30-50.

; LANGENEGGER, Natalia. Crítica à estrutura do Supremo Tribunal Federal por meio da teoria da agência: repensando a racionalidade da corte. XXI Congresso Nacional de Pesquisa e Pós Graduação em Direito. Niterói. Teoria e História do Direito Constitucional, 2012, pp. 396-420. Disponível em $<$ http://www.publicadireito.com.br/artigos/? cod $=322 \mathrm{f} 62469 \mathrm{c} 5 \mathrm{e} 3 \mathrm{c} 7 \mathrm{~d}>$. Acesso em 17 nov. de 2016. 
BARROSO, Luís Roberto. Judicialização da política, ativismo judicial e legitimidade democrática. Revista Jurídica da Presidência, Brasília, v. 12, n. 96, 2010, pp. $3-41$.

BENNETT MOSES, Lyria; CHAN, Janet. Using Big Data for Legal and Law Enforcement Decisions: Testing the New Tools. University of New South Wales Law Journal, Vol. 37, No. 2, 2014, pp. 643-678.

BENTHAM, Jeremy. Uma introdução aos princípios da moral e legislação. Trad. Luiz João Baraúna. São Paulo: Abril Cultural, 1979 [1789].

BENGOETXEA, Joxerramon. Reasoning from Consequences from Luxembourg. KOCH, Henning et al. (eds.). The New Legal Realism, Djøf Publishing, Copenhagen, 2010, pp. 39-56.

. Una defensa del consecuencialismo en el derecho. Telos - Revista Iberoamericana de estudios utilitaristas, vol. 2, pp. 31-68, 1993.

BESIO, Cristina; MEYER, Uli. Heterogeneity in World Society: How Organizations Handle Contradicting Logics. In: HOLZER, Boris; WERRON, Tobias; KASTNER, Fatima. From Globalization to World Society: Neo Institutional and Systems-Theoretical Perspectives. New York: Routledge, 2015, pp. 237-257. BIAZEVIC, Juan Paulo Haye. O raciocínio jurídico de Neil MacCormick: um estudo comparativo entre Legal Reasoning and Legal Theory e Rhetoric and the Rule of Law. 2016. 255f. Dissertação (Mestrado em Direito) - Faculdade de Direito, Universidade de São Paulo, São Paulo, 2016.

BINENBOJM, Gustavo. Agências Reguladoras e Democracia. Rio de Janeiro: Lúmen Juris, 2005.

BOBBIO, Norberto. Teoria da norma jurídica. Bauru, SP: Edipro, 2005 [1958].

A era dos direitos. Tradução de Carlos Nelson Coutinho. Rio de Janeiro: Elsevier, 2004 [1992].

BORA, Alfons. Capacidade de lidar com o futuro e responsabilidade por inovações - para o trato social com a temporalidade complexa. SCHWARTZ, Germano. Juridicização das esferas sociais e fragmentação do direito na sociedade contemporânea. Porto Alegre: Livraria do Advogado, 2012, pp. 127-145. . Technoscientific Normativity and the "Iron Cage" of Law. Science, Technology and Human Values, vol. 35, n. 1, 2010, pp. 3-28. 
BRASIL. Câmara dos Deputados. Decreto $n^{0}$ 19.711, de 18 de fevereiro de 1931. Disponível em: < http://www2.camara.leg.br/legin/fed/decret/19301939/decreto-19711-18-fevereiro-1931-517595-publicacaooriginal-1-pe.html>. Acesso em 17 jan. 2017.

BRASIL, Senado Federal. Projeto de Lei do Senado no 349, de 2015. Relator Antonio Anastasia. Inclui no Decreto-Lei ${ }^{\circ}$ 4.657, de 4 de setembro de 1942 (Lei de Introdução às Normas do Direito Brasileiro), disposições sobre segurança jurídica e eficiência na criação e na aplicação do direito público. Disponível em: $<$ https://www25.senado.leg.br/web/atividade/materias/-/materia/121664 > Acesso em 07 jun. 2017.

BRASIL, Supremo Tribunal Federal. Ação Declaratória de Constitucionalidade 19/DF. Plenário. Rel. Min. Marco Aurélio, j. 09.02.2012.

. Ação Declaratória de Constitucionalidade 9/DF. Plenário. Rel. para acórdão Min. Ellen Gracie, j. 23.04.2001.

. Ação Direta de Inconstitucionalidade 4815/DF. Plenário. Rel. Min. Cármen Lúcia, j. 10.06.2015.

. Ação Direta de Inconstitucionalidade 4568/DF. Plenário. Rel. Min. Cármen Lúcia, j. 29.03.2012.

. Ação Direta de Inconstitucionalidade 4432/PR. Plenário. Rel. Min. Dias Toffoli, j. 02.04.2011.

. Ação Direta de Inconstitucionalidade 4815/DF. Plenário. Rel. Min. Roberto Barroso, j. 29.05.2008.

. Ação Direta de Inconstitucionalidade 1348/RJ. Plenário. Rel. Min. Cármen Lúcia, j. 06.03.2008.

. Ação Direta de Inconstitucionalidade 1439/DF. Plenário. Rel. Min. Celso de Mello, j. 30.05.2003.

. Ação Direta de Inconstitucionalidade 2396/MS. Plenário. Rel. Min. Ellen Gracie, j. 01.08.2001.

. Ação Direta de Inconstitucionalidade 2358/RJ. Plenário. Rel. Min. Marco Aurélio, j. 15.02.2001.

. Ação Direta de Inconstitucionalidade 234/RJ. Plenário. Rel. Min. Néri da Silveira, j. 09.05.1997. 
BRASIL, Supremo Tribunal Federal. Ação Direta de Inconstitucionalidade 493/DF. Plenário. Rel. Min. Moreira Alves, j. 04.09.1992.

. Arguição de Descumprimento de Preceito Fundamental 347/DF. Plenário. Rel. Min. Marco Aurélio, j. 09.09.2015.

. Arguição de Descumprimento de Preceito Fundamental 101/DF. Plenário. Rel. Min. Cármen Lúcia, j. 24.06.2009.

. Recurso Extraordinário 363889/DF. Plenário. Rel. Min. Dias Toffoli, j. 02.06.2011.

. Recurso Extraordinário 141190/RJ. Plenário. Rel. para acórdão Min. Nelson Jobim, j. 26.05.2006

. Suspensão de Tutela Antecipada 185/DF. Rel. Min. Ellen Gracie, j. 10.12.2007.

BRAUDEL, Fernand. História e Ciências sociais: a longa duração. Revista de História, São Paulo, v. 30, n. 62, 1965 [1958], pp. 261-294.

BRESSER-PEREIRA, Luiz Carlos. Reforma gerencial e legitimação do estado social.

Revista Brasileira de Administração Pública, v. 51, 2017, pp. 147-156.

. Desenvolvimento e Crise no Brasil: História, Economia e Política de Getúlio

Vargas a Lula. São Paulo: Editora 34, 2003.

BRINK, David O. Legal Interpretation, Objectivity and Morality. In: LEITER, Brian (Ed.).

Objectivity in Law and Morals. Cambridge: Cambridge University Press, 2001, pp. 12-65.

BRINKLEY, Alan. The Unfineshed Nation: A concise history of the United States, New York: McGraw Hill, 2004.

BUSTAMANTE, Thomas; BUSTAMANTE, Evanilda Nascimento de Godoi Jurisdição Constitucional na Era Cunha: entre o Passivismo Procedimental e o Ativismo Substancialista do STF. Revista Direito e Práxis, v. 7, 2016, pp. 346-388.

CABRAL, Patrícia; MATTOS, César. Remédios em atos de concentração: teoria e prática do CADE. Revista da Defesa da Concorrência, v. 4, 2016, pp 57-94.

CALABRESI, Guido. Il futuro dell'analisi econômica del diritto. Sociologia del diritto. $n$. $1-2,1990$.

CAMPILONGO, Celso Fernandes. Prefácio. In: ARAÚJO, Thiago Cardoso. Análise Econômica do Direito no Brasil: Uma leitura à luz da Teoria dos Sistemas. Rio de Janeiro: Lumen Juris, 2016. 
CAMPILONGO, Celso Fernandes. Interpretação do direito e movimentos sociais. 1. ed. Rio de Janeiro: Elsevier, 2012 [2011].

O direito na sociedade complexa. São Paulo: Saraiva, 2011.

. Política, sistema jurídico e decisão judicial. São Paulo: Max Limonad, 2002 [2000].

; DE GIORGI, Raffaele; FARIA, José Eduardo. Opinião. Estado de coisas inconstitucional. O Estado de S. Paulo, São Paulo, 19 set 2015. Disponível em: $<$ http://opiniao.estadao.com.br/noticias/geral,estado-de-coisasinconstitucional,10000000043>. Acesso em: 30 out. 2015.

CAMPOS, Ricardo (org.). Crítica da Ponderação, método constitucional entre a dogmática jurídica e a teoria social - Ensaios traduzidos. São Paulo: Saraiva, 2016.

; LADEUR, Karl-Heinz. Entre teorias e espantalhos? Deturpações constitutivas na teoria dos princípios e novas abordagens. In: CAMPOS, Ricardo (org.). Crítica da Ponderação, método constitucional entre a dogmática jurídica e a teoria social - Ensaios traduzidos. São Paulo: Saraiva, 2016, p. 97-122.

CARBONELL, Flavia. Reasoning by consequences: applying different argumentation structures to the analysis of consequentialist reasoning in judicial decisions. In: DAHLMAN, Christian; FETERIS, Eveline (Eds.). Legal argumentation theory: cross-disciplinary perspectives. Berlin: Springer, 2013, pp. 1-19.

CARIELlo, Rafael. À procura de Leff. Revista Piauí, 2016. Disponível em $<$ http://piaui.folha.uol.com.br/materia/a-procura-de-leff/>. Acesso em 30 ago 2016.

CARVAlHO, José Murilo de. Cidadania no Brasil: o longo caminho. Rio de Janeiro: Civilização Brasileira, 2002.

. Dreams come untrue. Daedalus, Cambridge, Mass, v. 129, n.2, 2000, pp. 57-82.

CARVALHO NETO, Pythagoras Lopes de. Retórica e consistência no direito: Fundamentos para uma teoria do direito de inspiração luhmanniana. 181 fls. Tese (Doutorado em Direito) - Faculdade de Direito, Universidade de São Paulo, São Paulo, 2015.

CHASIN, Ana Carolina da Matta. A assimilação da arbitragem no Brasil: disputas em torno da constituição de uma justiça extraestatal. 198 f. Tese (Doutorado em 
Sociologia) - Faculdade de Filosofia, Letras e Ciências Humanas, Universidade de São Paulo, São Paulo, 2015.

CHRISTOPOULOS, Basile. Orçamento público e controle de constitucionalidade: argumentação consequencialista nas decisões do STF. Rio de Janeiro: Lumen Juris, 2016.

CLAM, Jean. Questões fundamentais de uma teoria da sociedade: contingência, paradoxo, só-efetuação. São Leopoldo: Unisinos, 2006 [2004].

COASE, Ronald. O Problema do Custo Social. In: Direito e Economia - Textos Escolhidos, Bruno Meyerhof Salama (org.). São Paulo: Saraiva, 2010 [1960], pp. 59-112.

COMELLA, Víctor. The Consequences of Centralizing Constitutional Review in a Special Court: Some Thoughts on Judicial Activism. Texas Law Review, v. 82, 2004, pp. 1705-1736.

CONSELHO NACIONAL DE JUSTIÇA. Justiça em Números. Disponível em: $<\mathrm{http}$ :/www.cnj.jus.br/\#/programas-e-acoes/pj-justica-em-numeros $>$. Acesso em: 22 mar. 2015.

CONSTABLE, Marianne. Just Silences: The Limits and Possibilities of Modern Law. Princeton: University Press, 2008.

CORREIA, José Gladston Viana. Sociologia dos direitos sociais: escassez, justiça e legitimidade. São Paulo: Saraiva, 2014.

CORSI, Giancarlo; ESPOSITO, Elena; BARALDI, Claudio. Glosario sobre la teoría social de Niklas Luhmann. Tradução de Miguel Romero Pérez e Carlos Villalobos. México: Universidad Iberoamericana; Guadalajara: Iteso; Barcelona: Anthropos, 1996.

COSTA, Emília Viotti da. STF: O Supremo Tribunal Federal e a construção da cidadania. São Paulo: Editora UNESP, 2006.

COUTINHO, Diogo Rosenthal. Capacidades Estatais no Programa Bolsa Família: o desafio de consolidação do Sistema Único da Assistência Social. Texto para Discussão IPEA. Brasília, v. 1, 2013, pp. 1-50, ; VOJVODIC, Adriana. (Coords.). Jurisprudência constitucional: como decide o STF? São Paulo: Malheiros, 2009.

COUTO, Cláudio; ARANTES, Rogério. Constituição, governo e democracia no Brasil. Revista Brasileira de Ciências Sociais (Impresso), v. 21, 2006, pp. 41-62. 
CSERNE, Peter. Consequence-based arguments in legal reasoning: a jurisprudential preface to law and economics. In: MATHIS, Klaus. (Ed.). Efficiency, sustainability and justice for future generations, Berlin: Springer, pp. 31-54, 2012.

CUNHA, Luciana; ALMEIDA, Frederico de. Justiça e desenvolvimento econômico na Reforma do Judiciário brasileiro. In: SHAPIRO, Mario; TRUBEK, David. Direito e desenvolvimento: um diálogo entre os BRICS. São Paulo: Saraiva, 2012, pp. 361-386.

DE GIORGI, Raffaele. Ciência do direito e legitimação: crítica da epistemologia jurídica alemã de Kelsen a Luhmann. Tradução de Pedro Jimenez Cortisano. Curitiba: Juruá, 2017 [1979].

. A investigação sociologia do direito na teoria dos sistemas. Direito UnB, v.02, n. 02, 2016, pp. 103-119.

. O risco na sociedade contemporânea. Revista de Direito Sanitário, Brasil, v. 9, n. 1, jun. 2008 [2006], p. 37-49.

. Sobre o Direito Kafka, Dürremat e a idéia de Luhmann sobre o Camelo, tradução de Virgílio de Mattos. Veredas do Direito, n. 7, 2007, pp. 29-43.

DEWEY, John. Reconstruction in philosophy. New York: Dover Publications, 2004 [1919].

. Logical Method and Law. Cornell Law Review, vol. 10, 1924. Disponível em: $<\mathrm{http}: / /$ scholarship.law.cornell.edu/clr/vol10/iss1/2>. Acesso em: 14 fev. de 2016.

DIAS, Juliana Melo; HERDY, Rachel. Probabilismo jurídico: o fetiche pelos números no direito. In: VIEIRA, José Ribas; LÍRIO DO VALLE, Vanice Regina; MARQUES, Gabriel Lima. (Orgs.). Democracia e suas instituições. Rio de Janeiro: Imo's, v. 1, 2014, pp. 23-36.

DIMOULIS, Dmitri. A Constituição interpretada sem regras. In: FALCÃO, Joaquim et al. (Org.). Onze Supremos. O Supremo em 2016. Belo Horizonte: Letramento, v. 1, 2017, pp. 63-65.

DUMÉNIL, Gérard; LÉVY, Dominique. Costs and Benefits of Neoliberalism: A Class Analysis. In: EPSTEIN, Gerald (ed.). Financialization and the World Economy. Aldershot: Edward Elgar, 2005. Disponível em: < http://www.peri.umass.edu/fileadmin/pdf/financial/fin_dumenil.pdf $>$. Acesso em 07 jun. de 2016. 
DUTRA, Roberto Torres. Diferenciação funcional e a sociologia da modernidade brasileira.

Política \& Sociedade (Online), v. 15, 2016, pp. 77-109.

; CAMPOS, Mauro Macedo. Por uma sociologia sistêmica da gestão de políticas públicas. Conexão Política, v. 2, 2014, pp. 11-47.

DWORKIN, Ronald. A Justiça de Toga. Tradução Jefferson Luiz Camargo. São Paulo, Martins Fontes, 2010 [2006].

. O império do direito. Tradução Jefferson Luiz Camargo. São Paulo: Martins Fontes, 1999 [1986].

EHRLICH, Eugen. Fundamental principles of the sociology of law. New Jersey: New Brunswick, 2009 [1913].

EINSENSTAD, Shmuel Noah. Multiples modernities. Daedalus, v. 129, n. 1, pp. 1-29, 2000. Disponível

em:

$<$ http://www.havenscenter.org/files/Eisenstadt2000_MultipleModernities.pdf $>$. Acesso em: 12 jan. 2016.

ELMAUER, Douglas. O direito na teoria crítica dos sistemas: da justiça autossubversiva à crítica imanente do direito. 316 f. Dissertação (Mestrado em Direito) Faculdade de Direito, Universidade de São Paulo, São Paulo, 2015.

ELSTER, Jon. Explaining Social Behavior: More Nuts and Bolts for the Social Sciences. Cambridge, UK: Cambridge University Press, 2007.

EPSTEIN, Lee; KNIGHT, Jack. The Economic Analysis of Judicial Behavior. In: EPSTEIN, Lee; LINDQUIST, Stefanie (eds.). The Oxford Handbook of U.S. Judicial Behavior. Oxford: Oxford University Press, 2017, pp. 320-339. Disponível em: $<$ http://epstein.wustl.edu/research/EconAnalysis.pdf $>$ Acesso em: 12 jun. 2017. ; MARTIN, Andrew. Quantitative Approaches to Empirical Legal Research. In: CANE, Peter; KRITZER, Hebert (eds.). The Oxford Handbook on Empirical Legal Studies. Oxford: Oxford University Press, 2010, pp. 901-925.

ESQUIROL, Jorge. The Failed Law of Latin America. The American Journal of Comparative Law, 2008, pp. 75-124.

FARIA, José Eduardo. O Supremo e o ativismo. O Estado de S. Paulo. 11 março 2017. Disponível em: $<$ http://opiniao.estadao.com.br/noticias/geral,o-supremo-e-oativismo-judicial,70001695353>. Acesso em: 10 mar. 2017. . Prefácio. In CAMPILONGO, Celso. Interpretação do direito e movimentos sociais. Rio de Janeiro: Elsevier, 2012, pp. ix-xv. 
FARIA, José Eduardo. O Estado e o Direito Depois da Crise. São Paulo: Saraiva, 2011.

FALCÃO, Joaquim. Eike, Lava-Jato e Mercado. Correio Braziliense. 15 fevereiro 2017.

Disponível em:

$<$ http://webcache.googleusercontent.com/search?q=cache:ovgZ0kZ1--

kJ:joaquimfalcao.com.br/2017/02/15/eike-lava-jato-e-

mercado/ $+\& \mathrm{~cd}=3 \& \mathrm{hl}=\mathrm{pt}-\mathrm{BR} \& \mathrm{ct}=\mathrm{clnk} \& \mathrm{gl}=\mathrm{br}>$. Acesso em: $18 \mathrm{fev}$. de 2017 .

. O Supremo, a Incerteza Judicial e a Insegurança Jurídica. Journal of Democracy, $\mathrm{N}^{\mathrm{o}}$. 2, 2016, pp. 79-97.

; OLIVEIRA, Fabiana Luci de. O STF e a Agenda Pública Nacional: de Outro

Desconhecido a Supremo Protagonista? Lua Nova, v. 88, 2012, pp. 429-469.

FALCÃO, Joaquim et al. Onze Supremos: O Supremo em 2016. 1. ed. Belo Horizonte: Letramento, 2017.

FALCÃO, Joaquim et al. I Relatório supremo em números: o múltiplo supremo. Rio de Janeiro: FGV Direito Rio, 2011.

FERRAZ, Octavio. Between Activism and Deference: Social rights adjudication in the Brazilian Supreme Federal Tribunal. In: GARCÍA, Helena; KLARE, Karl; WILliAMS, Lucy (eds). Social \& Economic Rights in Theory and Practice: A Critical Assessment. New York: Routledge, 2014, pp. 121-137.

FERRAZ JR., Tércio Sampaio. Teoria da Norma Jurídica: ensaio de pragmática da comunicação normativa. São Paulo: Editora Atlas, 2016.

Função Social da Dogmática Jurídica. São Paulo: Editora Atlas, 2015. . Argumentação jurídica. Barueri, SP: Manole, 2014.

. Teoria da norma jurídica: um modelo pragmático [sem data]. Disponível em: $<\mathrm{http}: / /$ www.terciosampaioferrazjr.com.br/?q=/publicacoes-cientificas/13>. Acesso em 12 dez. de 2017.

. Discussão. In: RODRIGUEZ, José Rodrigo; BARBOSA, Samuel Rodrigues (orgs.). Formalismo, dogmática jurídica e estado de direito: um debate sobre o direito contemporâneo a partir da obra de Tercio Sampaio Ferraz Jr. Cadernos de Direito FGV. São Paulo. v.7 n ${ }^{\circ} .3$, mai. 2010, pp. 13-22.

. Hermenêutica constitucional: interpretação de bloqueio e de legitimação. In FERRAZ JR., Tércio Sampaio. Direito constitucional: Liberdade de Fumar, Privacidade, Estado, Direitos Humanos e Outros Temas. Barueri, SP: Manole, 2007, pp.3-17. 
FERRAZ JR., Tércio Sampaio. Introdução ao Estudo do Direito: técnica, decisão, dominação. São Paulo: Atlas, 2001.

. A filosofia do direito no Brasil. Revista Brasileira de Filosofia, São Paulo, vol. XLV, Fasc. 197, 2000, pp. 12-30.

; MARANHÃO, Juliano. Função pragmática da justiça na hermenêutica jurídica: lógica do ou no direito? Revista do Instituto de Hermenêutica Jurídica, v. 1, pp. 273-318, 2007.

FERREIRA, Adriano de Assis. Advocacia em ebulição: A Ordem, o advogado e o profissionalismo [Kindle Edition], 2016.

FETERIS, Eveline. The rational reconstruction of weighing and balancing on the basis of teleological-evaluative considerations in the justifications of judicial decisions. Ratio Juris 21(4), 2008, pp 481-495.

. Fundamentos de la argumentación jurídica: revisión de las teorias sobre la justificación de las decisiones judiciales. trad. Alberto Supelano. Universidad Externardo de Colombia, 2007 [1999].

. The rational reconstruction of argumentation referring to consequences and purposes in the application of legal rules: a pragma-dialectical perspective. Argumentation, vol. 19, 2005, pp. 459-470.

; KLOOSTERHUIS, Harm. The analysis and evaluation of legal argumentation: approaches from legal theory and argumentation theory. Studies in Logic, Grammar and Rhetoric, 16 (29), 2009, pp 307-33.

FISCHER-LESCANO, Andreas. Força de Direito. Rio de Janeiro: Lumen Juris, 2017 [2013].

- A teoria crítica dos sistemas da escola de Frankfurt. Novos Estudos CEBRAP [online]. 2010 [2009], pp. 163-177.

FISCHER-LESCANO, Andreas; MOLLER, Kolja. Luta pelos Direitos Sociais Globais. Rio de Janeiro: Lumen Juris, 2017 [2012].

. (eds.) Transnationalisation of Social Rigths. Cambridge: Intersentia, 2016.

FRANK, Jerome. Law and the modern mind. Gloucester, Mass: Peter Smith, 1970 [1930].

FRIZZO-BARKER, Julie et al. An empirical study of the rise of big data in business scholarship. International Journal of Information Management, pp. 403413, 2016. 
FUCHS, Christian. Internet and Society: Social Theory in the Information Age. New York: Routledge, 2007.

FONSECA, Gabriel Ferreira da. A interpretação jurídica no Estado Regulador: da legislação racional à administração/jurisdição eficiente. 154 f. Dissertação (Mestrado em Direito) - Faculdade de Direito da Pontifícia Universidade Católica de São Paulo, São Paulo, 2016.

FUNDAÇÃO GETULIO VARGAS DE SÃO PAULO - FGV DIREITO SP. Índice de Confiança na Justiça Brasileira - ICJBrasil, 2017. Disponível em: $<$ http://bibliotecadigital.fgv.br/dspace/bitstream/handle/10438/19034/R elatorio-ICJBrasil_1_sem_2017.pdf?sequence=1\&isAllowed=y>. Acesso em: 17 de nov. de 2017.

GARCIA NETO, Paulo Macedo. A influência do realismo norte-americano no direito constitucional brasileiro. 187 f. Dissertação (Mestrado em Direito) - Faculdade de Direito da Universidade de São Paulo, São Paulo, 2008.

GARDBAUM, Stephen. Are Strong Constitutional Courts Always a Good Thing for New Democracies? Columbia Journal of Transnational Law, United States, v. 53, n. 2, 2015, pp. 285- 320 .

. The New Commonwealth Model of Constitutionalism: Theory and Practice. Cambridge: Cambridge University Press, 2013.

GIANNOTTI, José Arthur. Habermas: mão e contramão. Novos Estudos CEBRAP, n 31 , 1991, pp. 7-23.

GONÇALVES, Guilherme Leite. Pós-colonialismo e teoria dos sistemas: notas para uma agenda de pesquisa sobre o direito. In: BACHUR, João Paulo; DUTRA, Roberto (Orgs.). Dossiê Niklas Luhmann. Belo Horizonte: UFMG, 2013a, p. 249-277. . Direito entre certeza e incerteza: horizontes críticos para a teoria dos sistemas. 1. ed. São Paulo: Saraiva, 2013b.

; VILLAS BÔAS FILHO, Orlando. Teoria dos sistemas sociais: direito e sociedade na obra de Niklas Luhmann. São Paulo: Saraiva, 2013.

GUARNIERI, Carlo; PEDERZOLI, Patrizia. The Power of Judges: A comparative study of courts and democracy. Oxford: Oxford University Press, 2002.

GUERRA, Sérgio. Discricionariedade administrativa: limitações da vinculação legalitária e propostas pós-positivistas. In: SANTOS DE ARAGÃO, Alexandre; MARQUES 
NETO, Floriano de Azevedo (orgs.). Direito Administrativo e seus Novos Paradigmas. Belo Horizonte: Ed. Fórum, 2008, pp. 205-237.

HAACK, Susan. Perspectivas pragmatistas da filosofia do direito. São Leopoldo: Ed. Unisinos, 2015.

HAACK, Susan. O crescimento do significado e os limites do formalismo: perspectivas pragmatistas na ciência e no direito. tradução Rachel Herdy. In RODRIGUEZ, José Rodrigo (org.). A justificação do formalismo jurídico: textos em debate. São Paulo: Editora Saraiva, 2011, pp. 117-140.

HABERMAS, Jürgen. Direito e Democracia: entre facticidade e validade, vols. I e II. São Paulo: Tempo Brasileiro, 2003 [1992].

HART, Herbert L. A. A teoria do direito norte-americana pelos olhos ingleses: o pesadelo e o nobre sonho. In: MACEDO JR., Ronaldo Porto (coord.). Ensaios sobre teoria do direito e filosofia: H. L. A. Hart. Rio de Janeiro: Elsevier, 2010 [1977]. pp. $137-161$.

O Conceito de Direito. Lisboa: Fundação Calouste Gulbekian, 1994 [1961].

. Positivism and the Separation of Law and Morals. Harvard Law Review, 71 1958, pp. 593-629.

HART, Herbert L. A; HONORÉ, Tony. Causation in the Law. Oxford: Oxford University Press, 1985 [1959].

HARVARD LAW REVIEW. Statutory interpretation: Republic of Argentina V. NML Capital. Vol. 128: 381, 2014, pp 381-390. Disponível em: $<$ http://cdn.harvardlawreview.org/wpcontent/uploads/2014/11/Republic_of_argentina_v_NML_capital.pdf $>$ Acesso em: 02 de fev. de 2016.

HAYEK, Frederich. Individualism and Economic Order. Chicago: University of Chicago Press, 1958 [1948].

HENSEL, Isabell; TEUBNER, Günther. Horizontal Constitutional Rights as Conflict of Laws Rules: How Transnational Pharmagroups Manipulate Scientic Publications, 2014. Disponível em:< http://dx.doi.org/10.2139/ssrn.2432632> Acesso em: 02 de nov. de 2016.

HERDY, Rachel. Quando a ciência está em jogo, a democracia não importa. In: FALCÃO, Joaquim et al. (org.). Onze supremos: o supremo em 2016. 1ed.Belo Horizonte: Letramento, 2017, v. 1, pp. 46-47. 
HERDY, Rachel. The Epistemic Dependence of Judicial Decision-Makers. In: TAEKEMA, Sanne; VAN KLINK, Bart; DE BEEN, Wouter. (orgs.). Facts and Norms in Law: Interdisciplinary Reflections on Legal Method. Cheltenham, UK: Edward Elgar, 2016, pp. 82-99.

HIRSCHL, Ran. Towards Juristocracy: The Origins and Consequences of the New Constitucionalism. Cambridge, MA: Harvard University Press, 2007.

HOLMES JR., Oliver Wendell. The Common Law. New York: Barnes and Nobel, 1881 . The path of the Law. Harvard Law Review, v. 10, 1897, pp. 457-478.

HOLZER, Boris; WERRON, Tobias; KASTNER, Fatima. From Globalization to World Society: Neo Institutional and Systems-Theoretical Perspectives. New York: Routledge, 2015.

HOMERO. Ilíada. Tradução de Frederico de Lourenço. Lisboa: Livros Cotovia. 2005 [700a.C.].

HONNETH, Axel. Pathologies of Reason: On the Legacy of Critical Theory. New York: Columbia University Press, 2009.

HUME, David. Investigações sobre o entendimento humano e sobre os princípios da moral. São Paulo: Unesp, 2003 [1748].

IANNI, Octavio. Estado e Planejamento Econômico no Brasil. Rio de Janeiro, Civilização Brasileira, 1991.

JAERGER, Werner. Paidéia: a formação do homem grego. Tradução de Artur Perreira. São Paulo: Martins Fontes, 2003 [1943].

JAMES, William. O pragmatismo: um nome novo para algumas formas antigas de pensar. trad. Fernando Silva Martinho. Lisboa: Imprensa Nacional - Casa da Moeda, 1997 [1907].

JUNG, Courtney et al. Economic and Social Rights in National Constitutions. American Journal of Comparative Law, 62:4, 2014, pp 1043-1098.

KANT DE LIMA, Roberto; BAPTISTA, Barbara Gomes Lupetti. Como a Antropologia pode contribuir para a pesquisa jurídica? Um desafio metodológico. Anuário Antropológico, v. 39, 2014 pp. 9-37.

KAPISZEWSKI, Diana et al. Consequential Courts: Judicial Roles in Global Perspective. Cambridge : Cambridge University Press, 2013.

KELLEY, Patrick. Holmes, Langdell and Formalism. Ratio Juris, vol. 15, 2002, pp. 26-51. 
KENNEDY, David. A world of struggle: how power, law and expertise shape global political economy. United Kingdom: Princeton University Press, 2016.

KJAER, Poul. Systems in context: on the outcome of the Habermas/Luhmann- Debate. Ancilla Iuris, 2006, pp. 66-77.

KORNHAUSER, Lewis. The Great Image of Authority. Stanford Law Review, v. 36, Critical Legal Studies Symposium, 1984, pp. 349-389.

; SAGER, Lawrence. The One and the Many: Adjudication in Collegial Courts. California Law Review, n.91, 1993, pp. 1-51.

$\mathrm{KOCH}$, Martin. From International to World Organizarions. In: HOLZER, Boris; WERRON, Tobias; KASTNER, Fatima. From Globalization to World Society: Neo Institutional and Systems-Theoretical Perspectives. New York: Routledge, 2015, pp. 279-302.

KOERNER, Andrei. O debate sobre a Reforma do Judiciário. Novos Estudos Cebrap, n. 54, São Paulo, jul. 1999, pp. 11-26.

KRECKÉ, Elisabeth. Economic analysis and legal pragmatism. International Review of Law and Economics, vol. 23. 2004, pp 421-437.

KURTZ, Paul. Filosofia norteamerciana en el siglo veinte. Cidade do México: Fondo de Cultura Económica, 1972.

LADEUR, Karl-Heinz. Crítica da ponderação na dogmática dos direitos fundamentais apelo para uma renovação da teoria liberal dos direitos fundamentais. In: CAMPOS, Ricardo (org.). Crítica da Ponderação, método constitucional entre a dogmática jurídica e a teoria social - Ensaios traduzidos. São Paulo: Saraiva, 2016, pp. 133-224.

LARENZ, Karl. Metodologia da ciência do direito. Lisboa: Fundação Calouste Gulbenkian, 1969.

LEAL, Fernando Ângelo Ribeiro; MENDONÇA, José Vicente Santos (org.). Transformações do direito administrativo: Consequencialismo e estratégias regulatórias. Rio de Janeiro: Editora FGV, 2016.

LEITER, Brian. Explaining Theoretical Disagreement. The University of Chicago Law Review. Vol. 76, 2009, pp. 1215-1250.

. Naturalizing Jurisprudence: essays on American legal realism and naturalism in legal philosophy. Oxford: Oxford University Press, 2007. 
LIMA, Fernando Rister de Souza. Saúde e Supremo Tribunal Federal. Curitiba: Juruá Editora, 2015.

LIMA, Ticiana Nogueira. O processo administrativo no CADE e os problemas da regulação concorrencial brasileira. 169 f. Dissertação (Mestrado em Direito)

- Faculdade de Direito da Universidade de São Paulo, São Paulo, 2009

LLEWELLYN, Karl. The theory of rules. Chicago: The University of Chicago Press, 2011. . On the good, the true, the beautiful, in Law. Jurisprudence. 2 ed. Chicago; Londres: The University of Chicago Press, 1971.

. The Bramble Bush: on our law and its study. Columbia, 1930.

LOPES, José Reinaldo de Lima. Direito e economia: os caminhos do debate. In: LIMA, Maria Lúcia (Org.). Agenda contemporânea: direito e economia - 30 anos de Brasil. São Paulo, SP: Saraiva, 2012, v. 1, pp. 231-260.

. Direitos sociais: teoria e prática. São Paulo: Método, 2006.

LUHMANN, Niklas. La economía de la sociedade. Tradução Aldo Mascareño. Mexico: Herder, 2017 [1988].

. O direito da sociedade. Tradução Saulo Krieger. São Paulo: Martins Fontes, 2016 [1993].

. Communication about law in interaction systems. In KNORR-CETINA, K.; CICOUREL, A.V. Advances in Social Theory and Methodology: towards an integration of micro and macro sociologies. New York: Routledge, 2015 [1980], pp. 234-256.

. La moral de la sociedad. Tradução de Iván Ortega Rodríguez. Madrid: Editorial Trotta, 2013.

. Introdução à teoria dos sistemas. Petrópolis: Editora Vozes, 2010 [1996].

. La sociedad de la sociedad. Tradução de Javier Torres Nafarrate. México: Herder, 2007a [1997].

. Teoría política en el Estado de Bienestar. Tradução de Fernando Vallespín. Madrid: Alianza Universidad, 2007b [1987].

. Risk: a sociological theory. Tradução de Rhodes Barrett. New York: Gruyter, 2006 [1991].

. Iluminismo sociológico. Tradução de Artur Mourão. In: SANTOS, José Manuel (Org.). O pensamento de Niklas Luhmann. Corvilhã: Universidade da Beira Interior, 2005a [1967], pp.19-70. 
LUHMANN, Niklas. Organización y decisión. In: LUHMANN, Niklas. Organización y decisión. Autopoiesis, acción y entendimento comunicativo. Tradução de Darío Rodríguez Mansilla. México: Athropos, 2005b [1978], pp. 01-98.

. A Restituição do Décimo Segundo Camelo: Do Sentido de uma Análise Sociológica do Direito. Tradução de Dalmir Lopes Junior. In: ARNAUD, André- Jean; LOPES JUNIOR, Dalmir (Org.). Niklas Luhmann: Do Sistema Social à Sociologia Jurídica. Rio de Janeiro: Editora Lumen Juris, 2004 [1984], pp. 37 107.

. Causalidad nel Sud. In: CORSI, Giancarlo; DE GIORGI, Raffaele. Ridescrevere la questione meridionale. Lecce: Pensa Multimedia Editore, 1998 [1995], pp.91-121.

. Globalization or world society: how to conceive of modern society? International Review of Sociology: Revue Internationale de Sociologie, Roma, vol. 7, n. 1, pp. 67-79, 1997a.

. Entrevista realizada no dia 5.9.1994 em Foz do Iguaçu, PR. In: GUERRA FILHO, Willis Santiago. Autopoiese do Direito na Sociedade Pós-Moderna: introdução a uma teoria social sistêmica. Porto Alegre: Livraria do Advogado, 1997b, pp. 104-106.

. La ciencia de la sociedad. Tradução de Silvia Pappe, Brunhilde Erker e Luis Felipe Segura. Mexico D.F.: Anthropos, 1996 [1990].

. Social systems. Tradução de John Bednarz Jr. e Dirk Baecker. Stanford : Stanford University Press, 1995a [1984].

. Legal Argumentation: An Analysis of its Form. The Modern Law Reveiw, vol. 58,1995 b.

. What is the case? and What lies behind it? The two sociologies and the theory of society. Tradução de Stephen Fuchs. Sociological Theory, Vol. 12, nº. 2, 1994 [1993], pp 126-139.

. The code of the moral. Tradução de Jonathan Feldstein, Arthur J. Jacobson e

Gabriel Motzkin. Cardozo Law Review, New York, vol. 14, 1993c [1992], pp. 995-1009.

. Poder. Tradução de Martine Creusot de Rezende Martins. Brasília: UNB, 1985 [1975].

. Sociologia do Direito. v. I. Tradução de Gustavo Bayer. Rio de Janeiro: Tempo Brasileiro, 1983a [1972]. 
LUHMANN, Niklas. Sociologia do Direito. v. II. Tradução de Gustavo Bayer. Rio de Janeiro: Tempo Brasileiro, 1983b [1972].

. Sistema jurídico y dogmática jurídica. Tradução de Ignacio de Otto Pardo.Madrid. Centro de Estudios Constitucionales, 1983c [1974].

. Fin y racionalidad en los sistemas: sobre la funcion de los fines em los sistemas sociales. Tradução de Jaime Nicolás Muñiz. Madrid. Editora Nacional, 1982 [1968].

. The future cannot begin: temporal structures in modern society. Social Research, New York, vol. 43, n. 1, 1976, pp. 130-152.

MACCORMICK, Neil. Direito, interpretação e razoabilidade. In MACEDO JR., Ronaldo Porto. (org). Direito e interpretação: racionalidades e instituições. São Paulo: Saraiva, 2011, pp. 31-44.

. Rhetoric and the rule of law: a theory of legal reasoning. Oxford: Oxford University Press, 2005.

. Institutions of law: an essay in legal theory. Oxford: Oxford University Press, 2008.

. Argumentação jurídica e teoria do direito. São Paulo: Martins Fontes, 2006 [1978].

. On legal decisions and their consequences: from Dewey to Dworkin. New York University Law Review, vol. 58, n. 2, mai. 1983, pp. 239-58.

MACEDO, Bernardo Gouthier. Economia e direito: uma relação entre iguais. In: LIMA, Maria Lucia. (org.). Direito e economia 30 anos de Brasil - Tomo 1. $1^{\mathrm{a}}$ ed. São Paulo: Editora Saraiva, 2012, v. 1, pp. 213-229.

MACEDO JR., Ronaldo Porto. Do xadrez à cortesia: Dworkin e a teoria do direito contemporânea. 2 ed. São Paulo: Saraiva, 2014.

; PICCOLO, Carla Henriete Bevilacqua. Remarks on the Philosophy of Law in Brazil in the Twentieth Century. Anuario de Filosofia y Teoría del Derecho, v. 8, 2014, pp. 179-224.

; Posner e a Análise Econômica do Direito: da rigidez neoclássica ao pragmatismo frouxo. In: LIMA, Maria Lucia. (org.). Direito e economia 30 anos de Brasil Tomo 1. $1^{\text {a }}$ ed. São Paulo: Editora Saraiva, 2012, v. 1, pp. 260-281. 
MARQUES NETO, Floriano Peixoto de Azevedo; ARAGÃO, Alexandre Santos de (org.).

Direito Administrativo e Seus Novos Paradigmas. 1ª ed. Belo Horizonte: Editora Fórum, 2008.

MASCAREÑO, Aldo. La incompletitud de la autopoiesis. Irritación, codificación y crisis. Metapolítica 20, 2016, pp. 1-17.

MASCAREÑO, Aldo; CARVAJAL, Fabiola. The different faces of inclusion and exclusion. CEPAL Review, Vol. 2015/116, 2016.

MATIDA, Janaina; HERDY, Rachel. As inferências probatórias: compromissos epistêmicos, normativos e interpretativos. In: CUNHA, José Ricardo. (org.). Epistemologias críticas do direito. Rio de Janeiro: Lumen Juris, 2016, v. 1, p. 209-250.

MATTEI, Ugo; NADER, Laura. Plunder: when the rule of law is illegal. Oxford: Blackwell Publishing, 2008.

MENDES, Conrado Hübner. Onze Ilhas. Folha de São Paulo: Tendências e Debates, São Paulo, 01 fev. de 2010, disponível em:< http://www1.folha.uol.com.br/fsp/opiniao/fz0102201008.htm> . Acesso em: 03 jun. 2015.

MENDONÇA, Heloisa. Brasil vive entre a euforia do mercado e a realidade de milhões de desempregados. El País Brasil, 24 de fev. de 2017. Disponível em: $<$ https://brasil.elpais.com/brasil/2017/02/21/economia/1487704225_788947.ht ml>. Acesso em 04 abr 2017.

MERCURO, Nicholas; MEDEMA, Steven. Economics and the Law: From Posner to PostModernism. Princeton: Princeton Universty Press, 1999.

MICHELON JR., Cláudio Fortunato. Aceitação e objetividade: uma comparação entre as teses de Hart e do positivismo precedente sobre a linguagem e o conhecimento do direito. São Paulo: Revista dos Tribunais, 2004.

MINHOTO, Laurindo Dias; GONÇALVES, Guilherme Leite. Nova ideologia alemã? A teoria social envenenada de Niklas Luhmann. Tempo Social, v. 27, 2015, pp. 21-43.

MIOLA, Iagê Zendron. Direito da concorrência e neoliberalismo: a regulação da concentração econômica no Brasil. Revista Direito e Práxis, v. 7, 2016, pp.643689. 
MORAES, Ariane Cintra Lemos de. A expectativa da norma programática. $142 \mathrm{f}$. Dissertação (Mestrado em Direito) - Faculdade de Direito da Pontifícia Universidade Católica de São Paulo, São Paulo, 2009.

MORAES, Lafayette; ALVES, Carlos Roberto Teixeira. A modalidade a respeito dos futuros contingentes em Aristóteles, De Interpretatione 9. Cognitio (PUCSP), v. 10, 2009, pp. 243-266.

MORAES, Maria Cecília Bodin de. Do juiz boca-da-lei à lei boa-de-juiz: reflexões sobre a aplicação-interpretação do direito no início do século XXI. Revista de Direito Privado (São Paulo), v. 56, 2013, pp. 11-30.

MUÑOZ, Alberto Alonso. Transformações na Teoria Geral do Direito. São Paulo: Quartier Latin, 2008.

NAGLE, Luz Estella. The Cinderella of Government: Judicial Reform in Latin America. California Western International Law Journal, vol. 30, n. 2 , 2000, pp. 345-37.

NEVES, Marcelo. Entre Têmis e Leviatã: uma relação difícil. São Paulo: Martins Fontes, 2006 [2000].

. Pesquisa Interdisciplinar no Brasil: O Paradoxo da Interdisciplinaridade. Revista do Instituto de Hermenêutica Jurídica, Porto Alegre, v. 1, 2005, pp. 207-214. . Ideias em outro lugar? Constituição liberal e codificação do direito privado na virada do século XIX para o século XX no Brasil. In: FEBBRAJO, Alberto; LIMA, Fernando Rister; PUGLIESI, Márcio. (org.). Sociologia do direito: teoria e práxis. 1 ed. Curitiba: Juruá Editora, 2015, pp. 281-316.

NOBRE, Marcos. Indeterminação e estabilidade: os 20 anos da Constituição Federal e as tarefas da pesquisa em direito. Novos Estudos CEBRAP, v. 82, 2008, pp. 97106.

; RODRIGUEZ, José Rodrigo. Judicialização da política: déficits explicativos e bloqueios normativistas. Novos Estudos CEBRAP, 2011, pp. 05-20.

NONET, Philippe; SELZNICK, Philip. Direito e sociedade: a transição ao sistema jurídico responsivo. Tradução de Vera Ribeiro. Rio de Janeiro: Revan, 2010.

OLIVEIRA, Fabiana Luci. O Supremo Tribunal Federal e a política no Brasil contemporâneo. Cadernos Adenauer, v. 1, 2017, pp. 125-148.

. Agenda Suprema - interesses em disputa no controle de constitucionalidade das leis no Brasil. Tempo Social, Brasil, v. 28, n. 1, 2016, pp. 105-133. 
OLIVEIRA, Fabiana Luci. O Supremo Tribunal Federal no Processo de Transição Democrática: Uma Análise de Conteúdos dos Jornais Folha de S. Paulo e O Estado de S. Paulo. Revista de Sociologia Política, 22. Jun. 2004, pp. 101-117. PAIVA, Grazielle Alburquerque Moura. A reforma do judiciário no Brasil: o processo político de tramitação da emenda 45. 154 f. Dissertação (Mestrado em Políticas Públicas e Sociedade) - Universidade Estadual do Ceará, Ceará 2012.

PEREIRA, Cesar A. Guimarães. Discricionariedade e apreciação técnica da administração. Revista de Direito Administrativo, v. 231, 2003, pp. 217-268.

PERELMAN, Chaïm; OLBRECHTS-TYTECA, Lucie. Tratado da argumentação: a nova retórica. Tradução de Maria Ermantina Galvão. São Paulo: Martins Fontes, 1996 [1952].

PERELMAN, Chaïm. Lógica jurídica: nova retórica. Tradução de Vergínia K. Pupi. São Paulo: Martins Fontes, 1998 [1976].

PERROW, Charles. A society of organizations. Theory \& Society, v. 20, 1991, pp. 725762.

PISCITELLI, Tathiane dos Santos. Argumentando pelas consequências no Direito Tributário. São Paulo: Noeses, 2011.

POGREBINSCHI, Thamy. A Normatividade dos Fatos, as Consequências Políticas das Decisões Judiciais e o Pragmatismo do Supremo Tribunal Federal”. Revista de Direito Administrativo, v. 247, 2008, pp. 181-193.

POSNER, Richard. How Judges Think. Cambridge, MA: Harvard University Press, 2008. . Law, pragmatism and democracy. Cambridge, MA: Harvard University Press, 2003.

The problems of jurisprudence. Cambridge, MA: Harvard University Press, 1993 [1990].

POUND, Roscoe. Introduction. In: EHRLICH, Eugen. Fundamental principles of the sociology of law. New Jersey: New Brunswick, 2009, pp. xi-xviii,

. The scope and purpose of sociological jurisprudence. Harvard Law Review, v. XXV, 191, pp. 140-168.

PRADO, Mariana Mota; CHASIN, Ana Carolina da Matta. How Innovative was the Poupatempo Experience in Brazil? Institutional Bypass as a New Form of Institutional Change. Brazilian political science review, v. 5, 2011, pp. 11-34. 
PRADO, Mariana Mota; CARSON, Lindsey. Using Institutional Multiplicity to Address Corruption as a Collective Action Problem: Lessons from the Brazilian Case. Quarterly Review of Economics and Finance, Vol. 62, 2016, pp. 56-65.

PRADO JR., Caio Prado. Formação do Brasil Contemporâneo. São Paulo: Companhia das Letras, 2011[1942].

RAMOS, Luiz Felipe Rosa. Por trás dos casos difíceis: a dogmática jurídica e o paradoxo da decisão indecidível. 172 f. Dissertação (Mestrado em Direito) - Faculdade de Direito, Universidade de São Paulo, São Paulo, 2014.

REIS, Thiago. Dogmática e incerteza normativa: crítica ao substancialismo jurídico do direito civil-constitucional. Revista de Direito Civil Contemporâneo, v. 11, 2017, pp. 213-238.

RICUPERO, Bernardo. Da formação à forma: ainda as "ideias fora do lugar". Lua Nova, n.73, 2008, pp.59-69.

ROCHA, Leonel Severo; AZEVEDO, Guilherme de. Notas para uma teoria da organização da decisão jurídica autopoiética. Revista de Estudos Constitucionais, Hermenêutica e Teoria do Direito, v. 4, 2012, pp. 193-213.

RODRIGUES, Henrique Estrada. Lévi-Strauss, Braudel e o tempo dos historiadores. Revista Brasileira de História. vol.29, 2009, pp.165-186.

RODRIGUEZ, Caio Farah. Juízo e imaginação: da indeterminação jurídica à inovação institucional. São Paulo: Malheiros, 2016.

RODRIGUEZ, José Rodrigo. Estado de coisas surreal. Jota. 25 set de 2015. Disponível em: $<$ https://jota.info/artigos/estado-de-coisas-surreal-25092015>. Acessado em 12 dez. de 2015.

. Como decidem as cortes? Para uma crítica do direito (brasileiro). Rio de Janeiro: FGV, 2013.

. Fuga do Direito. Um estudo sobre o direito contemporâneo a partir de Franz Neumann. 1. ed. São Paulo: Saraiva, 2009.

RODRIGUEZ, José Rodrigo. et al. Dogmática é conflito: uma visão crítica da racionalidade jurídica ( $1^{\mathrm{a}}$ ed). São Paulo: Saraiva, 2012.

SADEK, Maria Tereza (coord). Magistrados: uma imagem em movimento. Rio de Janeiro: FGV, 2006.

. Judiciário: mudanças e reformas. Revista de Estudos Avançados, v.18, n.51, São Paulo, maio/ago. 2004, pp. 79-101. 
SADEK, Maria Tereza; ARANTES, Rogério. Introdução. In: SADEK, Maria Tereza (org.).

Reforma do Judiciário. São Paulo: Fundação Konrad Adenauer, 2001, pp.721.

SALAMA, Bruno Meyerhof. A história do declínio e queda do eficienctismo na obra de Richard Posner. In: LIMA, Maria Lucia. (org.). Direito e economia 30 anos de Brasil - Tomo 1. $1^{\text {a }}$ ed. São Paulo: Editora Saraiva, 2012, v. 1, pp. 284-321.

. O que é Pesquisa em Direito e Economia? Caderno Direito GV, n. 22, 2008. Disponível em:

$<\mathrm{http}$ ://www.direitogv.com.br/interna.aspx?PagId=HTKCNKWI\&IDCategory

$=4 \&$ IDSubCategory=139>. Acesso em: 15 de março de 2015.

; PARGENDLER, Mariana. Direito e Consequência no Brasil: Em Busca de um

Discurso sobre o Método. Revista de Direito Administrativo, v. 262, 2013, pp. 95-144.

SCHAFER, Burkhard. A Logical Journey: The Anxiety of the Lesniewski Quantifiers. In: DEL MAR, Maksymilian; MICHELON JR., Cláudio (ed.) The Anxiety of the Jurist. Ashgate Publishing, 2013, pp. 277-298.

; BAŃKOWSKI, Zenon Double-click Justice: Legalism in the Computer Age.

Legisprudence, vol 1, 2007 p. 31-49

SCHAPIRO, Mario; MARINHO, Sarah. Compliance concorrencial: cooperação regulatória na defesa da concorrência? Revista de Informação Legislativa, v. 53, 2016, pp. 273-299.

SCHAUER, Frederick. Formalismo. In: RODRIGUEZ, José Rodrigo (org.). A justificação do formalismo jurídico: textos em debate. 1ed.São Paulo: Saraiva, 2011, pp. 65-116

. Playing by the rules: A philosophical examination of rule-based decision-making in law and in life. Oxoford: Oxford University Press, 1991.

. Introduction. In: LLEWELLYN, Karl. The theory of rules. Chicago: The University of Chicago Press, 2011, pp. 1-28

SCHECAIRA, Fabio; STRUCHINER, Noel. Teoria da argumentação jurídica. Rio de Janeiro: Ed. PUC-Rio: Contraponto, 2016.

SCHUARTZ, Luiz Fernando. Consequencialismo jurídico, racionalidade decisória e malandragem. In: MACEDO JR., Ronaldo Porto. (org). Direito e 
interpretação: racionalidades e instituições. São Paulo: Saraiva, 2011, pp. 383418.

SCHUARTZ, Luiz Fernando. Quando o Bom é o Melhor Amigo do Ótimo. A Autonomia do Direito perante a Economia e a Política da Concorrência. Revista de Direito Administrativo, v. 1, 2007, pp. 96-127.

SCHUARTZ, Luiz Fernando et al. Jurisdição, Incerteza e Estado de Direito. Revista de Direito Administrativo, v. 1, 2006, pp. 79-112.

SCHUMPETER, Joseph. Capitalismo, socialismo e democracia. Traduzido por Ruy Jungmann). Rio de Janeiro: Editora Fundo de Cultura, 2013.

SCHWARZ, Roberto. Sequências brasileiras. São Paulo: Companhia das Letras, 1999.

SCOCUGLIA, Livia. Ministro Barroso propõe limitar reconhecimento de repercussão geral.

Consultor Jurídico. 26 ago. de 2014. Disponível em $<$ https://www.conjur.com.br/2014-ago-26/roberto-barroso-propoe-limitarrepercussao-geral-supremo>. Acessado em 16 dez 2015.

SEPÚLVEDA, Antônio Guimarães; BARBOSA, Carolina Almeida. O falacioso monopólio da última palavra. Quaestio Iuris, vol. 10, n. 3, 2017, pp. 1349-1369.

SINHORETTO, Jacqueline; ALMEIDA, Frederico de. Reforma do Judiciário: entre legitimidade e eficiência. In: SILVA, Felipe Gonçalves; RODRIGUEZ, José Rodrigo. (org.). Manual de Sociologia Jurídica. São Paulo: Saraiva, 2013, v. 1, pp. 197-218.

SMART, John Jamieson Carswell; BERNARD, Williams. Utilitarism: for and against. Cambridge: Cambridge University Press, 1989.

SOUZA, Jessé. Niklas Luhmann, Marcelo Neves e o "culturalismo cibernético" da moderna teoria sistêmica. In: BACHUR, J. P.; DUTRA, R. (org.). Dossiê Niklas Luhmann. 1ed.Belo Horizonte: Editora UFMG, 2013, pp. 149-182.

STICHWEH, Rudolf. Comparing Systems Theory and Sociologial Neo-Institutionalism: Explaining Functional Differentiation. In: HOLZER, Boris; WERRON, Tobias; KASTNER, Fatima. From Globalization to World Society: Neo Institutional and Systems-Theoretical Perspectives. New York: Routledge, 2015, pp. 2336

. Towards a General Theory of Function System Crises. In: TEUBNER, Gunther; FEBBRAJO, Alberto; KJAER, Poul. The financial crisis in constitutional 
perspective: the dark side of functional differentiation. Oxford: Hart Publishing, 2011, pp.43-60.

STRUCHINER, Noel. Indeterminação e objetividade. Quando o direito diz o que não queremos ouvir. In: MACEDO JR., Ronaldo Porto (org.). Direito e Interpretação. Racionalidades e Instituições. 1ed.São Paulo: Saraiva, 2011, pp. 119-152.

; TAVARES, Rodrigo de Souza (org.). Novas fronteiras da teoria do direito: da filosofia moral à psicologia experimental. Rio de Janeiro: POD/ Editora PUCRio, 2014.

SUNDFELD, Carlos Ari. A função administrativa no controle dos atos de concentração.

Revista de Direito Público da Economia, ano 1, nº 2, p.145-162, 2003.

SUPREMA CORTE DOS ESTADOS UNIDOS DA AMÉRICA. Republic of Argentina v. NML, 573 U. S. 2014. Disponível em: $<$ http://www.supremecourt.gov/opinions/13pdf/12-842_5hdk.pdf $>$. Acesso em: 27 de jan. de 2016.

Lochner v. New York, 198 U.S. 1905. Disponível em: $<$ https://supreme.justia.com/cases/federal/us/198/45/case.html>. Acesso em: 11 mar. de 2016.

. Dandridge v. Williams, 397 US 471. 1970. Disponivel em: $<$ https://supreme.justia.com/cases/federal/us/397/471/>. Acesso em: 18 set. de 2016.

SUPREMO TRIBUNAL FEDERAL. Estatísticas do STF - Controle Concentrado, 2017. Disponível em http://www.stf.jus.br/portal/cms/verTexto.asp?servico=estatistica\&pagina $=\mathrm{CC}$ _Geral>. Acessado em 18 out 2017.

TAYLOR, Matthew. Judging Policy: Courts and Policy Reform in Democratic Brazil. Stanford: Stanford University Press, 2008.

. O Judiciário e as políticas públicas no Brasil. Dados (Rio de Janeiro), v. 50, 2007, pp. 229-257.

. The Riddle of High Impact, Low Functionality Courts in Brazil. Revista de Economia Política, v. 25, n. 4, 2005, pp. 418-438.

TERRA, Ricardo; NOBRE, Marcos. (orgs.) Direito e Democracia: um guia de leitura de Habermas, São Paulo, Malheiros Editores, 2008. 
TEUBNER, Gunther. Direito e teoria social: três problemas. Tempo Social, v. 27, n. 2, dez. 2015, pp. 75-101.

. Bukowina global sobre a emergência de um pluralismo jurídico transnacional.

Direito e Globalização, 14, 2003, pp. 9-31.

Autopoiesis in Law and Society: A Rejoinder to Blankenburg. Law \& Society

Review, vol. 18, n.2, 1984, pp. 291-301.

TEUBNER, Gunther; FEBBRAJO, Alberto; KJAER, Poul. The financial crisis in constitutional perspective: the dark side of functional differentiation. Oxford: Hart Publishing, 2011

TOULMIN, Stephen Edelston. Os usos do argumento. Tradução de Reinaldo Guarany. 2. ed. São Paulo: Martins Fontes, 2006 [1958].

TREBILCOCK, Michael; DANIELS, Ronard. Rule of law reform and development: charting the fragile path of progress. Cheltenham, UK: Edward Elgar, 2008.

TRIBE, Lawrence. Trial by Mathematics: Precision and Ritual in the Legal Process. Harvard Law Review, vol. 84, n. 6, 1971, pp. 1329-1393.

TRUBEK, David. Max Weber sobre Direito e Ascensão do Capitalismo. Revista Direito GV, v. 3, n. 1, jan. 2007 [1972], pp. 151-185

TUSHNET, Mark. Weak-Form Judicial Review and "Core" Civil Liberties. Georgetown Law Faculty Publications and Other Works. 2006, pp. 1-22.

UNGER, Roberto Mangabeira. The Critical Legal Studies Movement: another time, a greater task. London: Verso, 2015.

O direito e o futuro da democracia. Tradução de Caio Farah Rodriguez e Márcio Soares Grandchamp. São Paulo: Boitempo, 2004.

VALLESPÍN, Fernando. Introducción. In: LUHMANN, Niklas. Teoría política en el Estado de Bienestar. Tradução de Fernando Vallespín. Madrid: Alianza Universidad, 2007, pp. 9-28.

VAMPRÉ, Spencer. As leis fundamentais da evolução jurídica. Revista da Faculdade de Direito, Universidade de São Paulo, São Paulo, v. 34, n. 2, 1938, pp. 103-121.

VANDERSTRAETEN, Raf. “Technical Knowledge and Instrumental Activism”. In: HOLZER, Boris; WERRON, Tobias; KASTNER, Fatima. From Globalization to World Society: Neo Institutional and Systems-Theoretical Perspectives. New York: Routledge, 2015, pp. 177-196 
VERMEULE, Adrian. Collective wisdom and institutional design. In: ELSTER, Jon; LANDEMORE, Hélène (eds.). Collective wisdom: principles and mechanisms. Cambridge: Cambridge University Press, 2012, pp. 338-367.

. Judging under Uncertainty: An Institutional Theory of Legal Interpretation. Cambridge, MA: Harvard University Press, 2006.

VESTING, Thomas. Vizinhança - Direitos fundamentais e sua teoria na cultura das redes. In: CAMPOS, Ricardo (org.). Crítica da Ponderação, método constitucional entre a dogmática jurídica e a teoria social - Ensaios traduzidos. São Paulo: Saraiva, 2016, pp. 225-270.

. Teoria do direito: uma introdução. Tradução de Gercélia Mendes. São Paulo: Saraiva, 2015.

VIEHWEG, Theodor. Tópica e Jurisprudência. Tradução de Tércio Sampaio Ferraz Jr. Brasília: Departamento de Imprensa Nacional, 1979.

VIEIRA, Oscar Vilhena. Supremocracia. Revista Direito GV, São Paulo, v. 4, 2008, pp. $441-459$.

. Que Reforma? Revista de Estudos Avançados, v.18, n.51, São Paulo, maio/ago. 2004, pp. 195-207.

VILLAS BÔAS FILHO, Orlando. O direito de qual sociedade? Os limites da descrição sociológica de Niklas Luhmann acerca do direito a partir da crítica antropológica. In: FEBBRAJO, Alberto; LIMA, Fernando Rister; PUGLIESI, Márcio. (org.). Sociologia do direito: teoria e práxis. 1 ed. Curitiba: Juruá Editora, 2015, pp. 337-366.

. Teoria dos Sistemas e o Direito Brasileiro. São Paulo: Saraiva, 2009.

VOJVODIC, Adriana de Moraes et al. Escrevendo um romance, primeiro capítulo: precedentes e processo decisório no STF. Revista Direito GV. 2009, vol.5, n.1, pp.21-44.

WAISMANN, Friedrich. Symposium Verifiability. Proceedings of the Aristotelian Society, Supplementary Volumes, vol. 19, Analysis and Metaphysics, 1945.

WALDRON, Jeremy. The Core of the Case against Judicial Review. The Yale Law Journal, New Haven, v. 115, 2006, pp. 1346-1406.

WANG, Daniel. Right To Health Litigation In Brazil: The Problem And The Institutional Responses. Human Rights Law Review, v. 15, 2015, pp. 617-641. 
WEBER, Max. Economy and society: an outline of interpretive sociology. Editado por Guenther Roth e Claus Wittich. Berkeley: University of California Press, 1978. . Metodologias das ciências sociais. São Paulo: Cortez, 2001.

WERNECK VIANNA, Luiz; BURGOS, Marcelo Baumann; SALLES, Paula Martins. Dezessete anos de judicialização da política . Tempo Social, v. 19, n. 2, nov. 2007, pp. 39-85,

WRÓBLEWSKI, Jerzy. Legal syllogism and rationality of judicial decision. Reschtstheorie, 1974, pp 33-46.

WRÓBLEWSKI, Jerzy. Justification through principles and justification through consequences. In: C. Farrali, C; Pattaro, E. (eds.) Reason in Law, Milano: Giuffrè, 1984, pp 129-161.

. The judicial application of the law. Dordrecht: Kluwer, 1992.

YOUNG, Katharine G. Constituting economic and social rights. Oxford: Oxford University Press, 2012.

ZANATTA, Rafael. Desmistificando a Law \& Economics: a receptividade da disciplina direito e economia no Brasil. Revista dos estudantes de direito da Universidade de Brasília, v. 10, 2012 pp. 25-53. 


\section{ANEXOS}

Anexo 1 - Amostra da pesquisa (conjunto de ações de controle concentrado de constitucionalidade transitadas em julgado sobre direitos econômicos em 1988 a 2017).

\begin{tabular}{|c|c|c|c|c|c|c|c|c|c|c|}
\hline Tipo & Proc. & $\begin{array}{c}\text { Ano } \\
\text { Ingresso }\end{array}$ & $\begin{array}{l}\text { Ano } \\
\text { final }\end{array}$ & Decisão & Colegiado & Origem & Autor & Requerido & Relator & Controvérsia \\
\hline ADI & 2 & 1988 & 1992 & Negado seguimento & Majoritária & Federal & Associação/Confederação/Sindicato & Executivo Federal & Paulo Brossard & $\begin{array}{l}\text { Fixação de preços de } \\
\text { produtos/serviço }\end{array}$ \\
\hline ADI & 4 & 1988 & 1993 & Improcedente & Majoritária & Federal & Partido Político & Executivo Federal & $\begin{array}{l}\text { Sydney } \\
\text { Sanches }\end{array}$ & $\begin{array}{l}\text { Regulação da atividade } \\
\text { econômica }\end{array}$ \\
\hline ADI & 8 & 1988 & 1996 & Negado seguimento & Unânime & Federal & Associação/Confederação/Sindicato & Executivo Federal & Carlos Velloso & $\begin{array}{l}\text { Fixação de preços de } \\
\text { produtos/serviço }\end{array}$ \\
\hline $\mathrm{ADC}$ & 9 & 2001 & 2001 & Procedente & Majoritária & Federal & Presidente da República & Executivo Federal & Ellen Gracie & $\begin{array}{l}\text { Regulação da atividade } \\
\text { econômica }\end{array}$ \\
\hline $\mathrm{ADO}$ & 16 & 2011 & 2012 & Negado seguimento & Monocrática & Federal & Associação/Confederação/Sindicato & Legislativo Federal & Marco Aurélio & $\begin{array}{l}\text { Sistema de consórcios e } \\
\text { sorteios }\end{array}$ \\
\hline $\mathrm{ADO}$ & 17 & 2011 & 2012 & Negado seguimento & Monocrática & Federal & Associação/Confederação/Sindicato & Legislativo Federal & Marco Aurélio & $\begin{array}{l}\text { Sistema de consórcios e } \\
\text { sorteios }\end{array}$ \\
\hline $\mathrm{ADO}$ & 18 & 2011 & 2013 & Negado seguimento & Monocrática & Federal & Associação/Confederação/Sindicato & Legislativo Federal & $\begin{array}{l}\text { Roberto } \\
\text { Barroso }\end{array}$ & Proposta orçamentária \\
\hline $\mathrm{ADO}$ & 19 & 2011 & 2013 & Negado seguimento & Monocrática & Federal & Associação/Confederação/Sindicato & Legislativo Federal & $\begin{array}{l}\text { Roberto } \\
\text { Barroso } \\
\end{array}$ & Proposta orçamentária \\
\hline ADI & 34 & 1989 & 1989 & Negado seguimento & Unânime & Federal & Associação/Confederação/Sindicato & Executivo Federal & \begin{tabular}{|l|} 
Octavio \\
Gallotti \\
\end{tabular} & $\begin{array}{l}\text { Programa de } \\
\text { desestatização }\end{array}$ \\
\hline ADPF & 37 & 2002 & 2010 & Negado seguimento & Monocrática & Estadual & Governador & \begin{tabular}{|l|} 
Legislativo \\
Estadual
\end{tabular} & Dias Toffoli & Proposta orçamentária \\
\hline ADI & 45 & 2003 & 2004 & Negado seguimento & Monocrática & Federal & Partido Político & Executivo Federal & Celso de Mello & Proposta orçamentária \\
\hline ADPF & 45 & 2003 & 2004 & Negado seguimento & Monocrática & Federal & Partido Político & Executivo Federal & Celso de Mello & Proposta orçamentária \\
\hline ADI & 49 & 1989 & 2001 & Negado seguimento & Monocrática & Federal & Associação/Confederação/Sindicato & Executivo Federal & $\begin{array}{l}\text { Maurício } \\
\text { Correa } \\
\end{array}$ & $\begin{array}{l}\text { Fixação de indíce } \\
\text { econômico }\end{array}$ \\
\hline
\end{tabular}




\begin{tabular}{|c|c|c|c|c|c|c|c|c|c|c|}
\hline Tipo & Proc. & $\begin{array}{r}\text { Ano } \\
\text { Ingresso }\end{array}$ & $\begin{array}{l}\text { Ano } \\
\text { final }\end{array}$ & Decisão & Colegiado & Origem & Autor & Requerido & Relator & Controvérsia \\
\hline ADI & 50 & 1989 & 1992 & Negado seguimento & Monocrática & Federal & Partido Político & Executivo Federal & $\begin{array}{l}\text { Octavio } \\
\text { Gallotti }\end{array}$ & $\begin{array}{l}\text { Programa de } \\
\text { desestatização }\end{array}$ \\
\hline $\mathrm{ADPF}$ & 63 & 2005 & 2010 & Negado seguimento & Monocrática & Estadual & Governador & \begin{tabular}{|l|} 
Legislativo \\
Estadual \\
\end{tabular} & Dias Toffoli & Proposta orçamentária \\
\hline ADPF & 64 & 2005 & 2005 & Negado seguimento & Monocrática & Estadual & Governador & $\begin{array}{l}\text { Legislativo } \\
\text { Estadual }\end{array}$ & Carlos Velloso & Proposta orçamentária \\
\hline ADPF & 73 & 2005 & 2007 & Negado seguimento & Monocrática & Federal & Partido Político & Executivo Federal & Eros Grau & Proposta orçamentária \\
\hline ADI & 90 & 1989 & 1997 & Improcedente & Unânime & Federal & Associação/Confederação/Sindicato & Executivo Federal & \begin{tabular}{|l|} 
Octavio \\
Gallotti \\
\end{tabular} & $\begin{array}{l}\text { Fixação de preços de } \\
\text { produtos/serviço }\end{array}$ \\
\hline ADPF & 91 & 2006 & 2006 & Negado seguimento & Monocrática & Estadual & Prefeito Municipal & \begin{tabular}{|l|} 
Legislativo \\
Municipal \\
\end{tabular} & Celso de Mello & Proposta orçamentária \\
\hline ADPF & 93 & 2006 & 2009 & Negado seguimento & Majoritária & Federal & Associação/Confederação/Sindicato & Executivo Federal & \begin{tabular}{|l|} 
Ricardo \\
Lewandowski \\
\end{tabular} & $\begin{array}{l}\text { Regulação da atividade } \\
\text { econômica }\end{array}$ \\
\hline ADI & 107 & 1989 & 2001 & Negado seguimento & Monocrática & Estadual & Associação/Confederação/Sindicato & \begin{tabular}{|l|} 
Legislativo \\
Estadual \\
\end{tabular} & Nelson Jobim & $\begin{array}{l}\begin{array}{l}\text { Regulação da atividade } \\
\text { econômica }\end{array} \\
\end{array}$ \\
\hline ADPF & 113 & 2007 & 2015 & Negado seguimento & Monocrática & Federal & Partido Político & Poder Judiciário & Celso de Mello & Planos econômicos \\
\hline ADPF & 128 & 2008 & 2008 & Negado seguimento & Monocrática & Federal & Associação/Confederação/Sindicato & Poder Judiciário & Cezar Peluso & $\begin{array}{l}\text { Sistema de consórcios e } \\
\text { sorteios }\end{array}$ \\
\hline ADI & 133 & 1989 & 2006 & Negado seguimento & Monocrática & \begin{tabular}{|l|} 
Ministério \\
Público
\end{tabular} & Associação/Confederação/Sindicato & Executivo Federal & Gilmar Mendes & $\begin{array}{l}\text { Fixação de indíce } \\
\text { ecoômico }\end{array}$ \\
\hline ADPF & 147 & 2008 & 2011 & Negado seguimento & Unânime & Federal & Associação/Confederação/Sindicato & Poder Judiciário & Carmen Lucia & $\begin{array}{l}\text { Sistema de consórcios e } \\
\text { sorteios }\end{array}$ \\
\hline ADI & 156 & 1989 & 2001 & Negado seguimento & Monocrática & Federal & Associação/Confederação/Sindicato & Executivo Federal & Néri da Silveira & $\begin{array}{l}\text { Fixação de indíce } \\
\text { econômico }\end{array}$ \\
\hline ADI & 166 & 1989 & 1996 & Negado seguimento & Unânime & Estadual & Associação/Confederação/Sindicato & \begin{tabular}{|l|} 
Legislativo \\
Estadual \\
\end{tabular} & Ilmar Galvão & Operações de crédito \\
\hline ADI & 195 & 1990 & 2004 & Negado seguimento & Monocrática & Federal & Associação/Confederação/Sindicato & Executivo Federal & Nelson Jobim & $\begin{array}{l}\text { Regulação da atividade } \\
\text { econômica }\end{array}$ \\
\hline ADPF & 210 & 2010 & 2013 & Negado seguimento & Unânime & Federal & Associação/Confederação/Sindicato & Conselhos & Teori Zavascki & $\begin{array}{l}\text { Regulação da atividade } \\
\text { econômica }\end{array}$ \\
\hline ADI & 211 & 1990 & 1990 & Negado seguimento & Unânime & Federal & Associação/Confederação/Sindicato & Executivo Federal & Moreira Alves & $\begin{array}{l}\text { Programa de } \\
\text { desestatização }\end{array}$ \\
\hline
\end{tabular}




\begin{tabular}{|c|c|c|c|c|c|c|c|c|c|c|}
\hline Tipo & Proc. & $\begin{array}{r}\text { Ano } \\
\text { Ingresso }\end{array}$ & $\begin{array}{r}\text { Ano } \\
\text { final }\end{array}$ & Decisão & Colegiado & Origem & Autor & Requerido & Relator & Controvérsia \\
\hline ADPF & 229 & 2011 & 2012 & Negado seguimento & Monocrática & Federal & Associação/Confederação/Sindicato & Poder Judiciário & $\begin{array}{l}\text { Ricardo } \\
\text { Lewandowski }\end{array}$ & $\begin{array}{l}\text { Piso salarial/remuneração } \\
\text { de categoria profissional }\end{array}$ \\
\hline ADI & 234 & 1990 & 1995 & $\begin{array}{l}\text { Parcialmente } \\
\text { procedente }\end{array}$ & Unânime & Estadual & Governador & \begin{tabular}{|l|} 
Legislativo \\
Estadual \\
\end{tabular} & Néri da Silveira & $\begin{array}{l}\text { Programa de } \\
\text { desestatização }\end{array}$ \\
\hline $\mathrm{ADI}$ & 252 & 1990 & 1997 & Negado seguimento & Majoritária & Estadual & Procurador-Geral da República & Executivo Estadual & Moreira Alves & $\begin{array}{l}\text { Regulação da atividade } \\
\text { econômica }\end{array}$ \\
\hline ADI & 280 & 1990 & 2007 & Procedente & Unânime & Estadual & Governador & \begin{tabular}{|l|} 
Legislativo \\
Estadual
\end{tabular} & $\begin{array}{l}\text { Francisco } \\
\text { Rezek }\end{array}$ & $\begin{array}{l}\text { Regulação da atividade } \\
\text { econômica }\end{array}$ \\
\hline ADI & 287 & 2013 & 2014 & Negado seguimento & Monocrática & Estadual & Governador & Executivo Federal & Dias Toffoli & $\begin{array}{l}\text { Regulação da atividade } \\
\text { econômica }\end{array}$ \\
\hline ADPF & 287 & 2013 & 2014 & Negado seguimento & Monocrática & Estadual & Governador & Executivo Federal & Dias Toffoli & $\begin{array}{l}\text { Regulação da atividade } \\
\text { econômica }\end{array}$ \\
\hline $\mathrm{ADI}$ & 319 & 1990 & 1992 & $\begin{array}{l}\text { Parcialmente } \\
\text { procedente }\end{array}$ & Unânime & Federal & Associação/Confederação/Sindicato & Executivo Federal & Moreira Alves & $\begin{array}{l}\text { Regulação da atividade } \\
\text { econômica }\end{array}$ \\
\hline ADI & 329 & 1990 & 2004 & Procedente & Unânime & Estadual & Procurador-Geral da República & \begin{tabular}{|l|} 
Legislativo \\
Estadual \\
\end{tabular} & Ellen Gracie & $\begin{array}{l}\text { Regulação da atividade } \\
\text { econômica }\end{array}$ \\
\hline ADPF & 333 & 2015 & 2015 & Negado seguimento & Monocrática & Estadual & Associação/Confederação/Sindicato & Poder Judiciário & Carmen Lucia & Consumidor \\
\hline ADI & 334 & 1990 & 1993 & Negado seguimento & Majoritária & Federal & Associação/Confederação/Sindicato & Executivo Federal & Moreira Alves & $\begin{array}{l}\text { Piso salarial/remuneração } \\
\text { de categoria profissional }\end{array}$ \\
\hline ADI & 357 & 1990 & 1997 & Negado seguimento & Monocrática & Federal & Partido Político & Executivo Federal & Carlos Velloso & $\begin{array}{l}\text { Piso salarial/remuneração } \\
\text { de categoria profissional }\end{array}$ \\
\hline ADI & 358 & 1990 & 1994 & Negado seguimento & Monocrática & Federal & Associação/Confederação/Sindicato & Executivo Federal & Carlos Velloso & $\begin{array}{l}\text { Piso salarial/remuneração } \\
\text { de categoria profissional }\end{array}$ \\
\hline ADI & 359 & 1990 & 1993 & Negado seguimento & Monocrática & Federal & Partido Político & Executivo Federal & Carlos Velloso & $\begin{array}{l}\text { Piso salarial/remuneração } \\
\text { de categoria profissional }\end{array}$ \\
\hline ADI & 360 & 1990 & 1990 & Negado seguimento & Unânime & Federal & Associação/Confederação/Sindicato & Executivo Federal & Moreira Alves & $\begin{array}{l}\text { Piso salarial/remuneração } \\
\text { de categoria profissional }\end{array}$ \\
\hline ADI & 361 & 1990 & 1998 & Negado seguimento & Monocrática & Federal & Partido Político & Executivo Federal & Marco Aurélio & $\begin{array}{l}\text { Regulação da atividade } \\
\text { econômica }\end{array}$ \\
\hline ADI & 384 & 1990 & 1997 & Negado seguimento & Majoritária & Estadual & Associação/Confederação/Sindicato & Executivo Estadual & Moreira Alves & $\begin{array}{l}\text { Regulação da atividade } \\
\text { econômica }\end{array}$ \\
\hline ADI & 418 & 1990 & 1990 & Negado seguimento & Unânime & Federal & Procurador-Geral da República & Executivo Federal & Moreira Alves & $\begin{array}{l}\text { Regulação da atividade } \\
\text { econômica }\end{array}$ \\
\hline ADI & 427 & 1991 & 1993 & Negado seguimento & Monocrática & Federal & $\mathrm{OAB}$ & Executivo Federal & Marco Aurélio & $\begin{array}{l}\text { Piso salarial/remuneração } \\
\text { de categoria profissional }\end{array}$ \\
\hline
\end{tabular}




\begin{tabular}{|c|c|c|c|c|c|c|c|c|c|c|}
\hline Tipo & Proc. & $\begin{array}{r}\text { Ano } \\
\text { Ingresso }\end{array}$ & $\begin{array}{l}\text { Ano } \\
\text { final }\end{array}$ & Decisão & Colegiado & Origem & Autor & Requerido & Relator & Controvérsia \\
\hline ADI & 435 & 1991 & 1993 & Negado seguimento & Monocrática & Federal & Partido Político & Executivo Federal & Carlos Velloso & $\begin{array}{l}\text { Piso salarial/remuneração } \\
\text { de categoria profissional }\end{array}$ \\
\hline ADI & 473 & 1991 & 1998 & Negado seguimento & Unânime & Estadual & Procurador-Geral da República & $\begin{array}{l}\text { Legislativo } \\
\text { Estadual }\end{array}$ & Néri da Silveira & $\begin{array}{l}\text { Programa de } \\
\text { desestatização }\end{array}$ \\
\hline ADI & 477 & 1991 & 1999 & Negado seguimento & Monocrática & Federal & Partido Político & Executivo Federal & Carlos Velloso & Salário mínimo \\
\hline ADI & 485 & 1991 & 1991 & Negado seguimento & Unânime & Federal & Partido Político & Executivo Federal & Celio Borja & $\begin{array}{l}\text { Programa de } \\
\text { desestatização }\end{array}$ \\
\hline ADI & 493 & 1991 & 1992 & Procedente & Majoritária & Federal & Procurador-Geral da República & Executivo Federal & Moreira Alves & $\begin{array}{l}\text { Fixação de indíce } \\
\text { econômico }\end{array}$ \\
\hline $\mathrm{ADI}$ & 496 & 1991 & 1992 & Negado seguimento & Unânime & Federal & Partido Político & Executivo Federal & Moreira Alves & $\begin{array}{l}\text { Fixação de indíce } \\
\text { econômico }\end{array}$ \\
\hline ADI & 504 & 1991 & 2001 & Negado seguimento & Monocrática & Federal & Procurador-Geral da República & Executivo Federal & $\begin{array}{l}\text { Maurício } \\
\text { Correa }\end{array}$ & $\begin{array}{l}\text { Regulação da atividade } \\
\text { econômica }\end{array}$ \\
\hline ADI & 534 & 1991 & 1992 & Negado seguimento & Unânime & Federal & Partido Político & Executivo Federal & Celso de Mello & Planos econômicos \\
\hline ADI & 562 & 1991 & 1998 & Negado seguimento & Unânime & Federal & Partido Político & Executivo Federal & Ilmar Galvão & $\begin{array}{l}\text { Programa de } \\
\text { desestatização }\end{array}$ \\
\hline ADI & 586 & 1991 & 2000 & Negado seguimento & Monocrática & Federal & Mesa Assembleia & Executivo Federal & Ilmar Galvão & \begin{tabular}{|l|l} 
Programa de \\
desestatização
\end{tabular} \\
\hline ADI & 589 & 1991 & 1991 & Negado seguimento & Unânime & Federal & Partido Político & Executivo Federal & Carlos Velloso & \begin{tabular}{|l|} 
Programa de \\
desestatização
\end{tabular} \\
\hline ADI & 605 & 1991 & 2002 & Negado seguimento & Monocrática & Federal & Partido Político & Executivo Federal & Celso de Mello & Operações de crédito \\
\hline $\mathrm{ADI}$ & 608 & 1991 & 2007 & Improcedente & Majoritária & Federal & Partido Político & Executivo Federal & Carmen Lucia & $\begin{array}{l}\text { Fixação de indíce } \\
\text { econômico }\end{array}$ \\
\hline ADI & 655 & 1991 & 2004 & Negado seguimento & Monocrática & Federal & Procurador-Geral da República & Executivo Federal & \begin{tabular}{|l} 
Joaquim \\
Barbosa
\end{tabular} & $\begin{array}{l}\text { Regulação da atividade } \\
\text { econômica }\end{array}$ \\
\hline ADI & 708 & 1992 & 1992 & Negado seguimento & Unânime & Estadual & Procurador-Geral da República & Executivo Federal & Moreira Alves & $\begin{array}{l}\text { Regulação da atividade } \\
\text { econômica }\end{array}$ \\
\hline ADI & 768 & 1992 & 2002 & Negado seguimento & Monocrática & Federal & Associação/Confederação/Sindicato & Executivo Federal & Carlos Velloso & $\begin{array}{l}\text { Fixação de indíce } \\
\text { econômico }\end{array}$ \\
\hline ADI & 783 & 1992 & 2001 & Negado seguimento & Monocrática & Federal & Procurador-Geral da República & Executivo Federal & Carlos Velloso & $\begin{array}{l}\text { Regulação da atividade } \\
\text { econômica }\end{array}$ \\
\hline ADI & 835 & 1993 & 2002 & Negado seguimento & Monocrática & Federal & Associação/Confederação/Sindicato & Executivo Federal & Celso de Mello & $\begin{array}{l}\text { Fixação de indíce } \\
\text { econômico }\end{array}$ \\
\hline
\end{tabular}




\begin{tabular}{|c|c|c|c|c|c|c|c|c|c|c|}
\hline Tipo & Proc. & \begin{tabular}{r|} 
Ano \\
Ingresso
\end{tabular} & $\begin{array}{r}\text { Ano } \\
\text { final }\end{array}$ & Decisão & Colegiado & Origem & Autor & Requerido & Relator & Controvérsia \\
\hline ADI & 855 & 1993 & 2009 & Procedente & Majoritária & Estadual & Associação/Confederação/Sindicato & Executivo Estadual & $\begin{array}{l}\text { Octavio } \\
\text { Gallotti }\end{array}$ & Consumidor \\
\hline ADI & 886 & 1993 & 2002 & Negado seguimento & Monocrática & Federal & Associação/Confederação/Sindicato & Executivo Federal & Carlos Velloso & $\begin{array}{l}\text { Fixação de indíce } \\
\text { econômico }\end{array}$ \\
\hline ADI & 910 & 1993 & 2003 & Procedente & Unânime & Estadual & Procurador-Geral da República & Executivo Estadual & $\begin{array}{l}\text { Maurício } \\
\text { Correa } \\
\end{array}$ & $\begin{array}{l}\text { Regulação da atividade } \\
\text { econômica }\end{array}$ \\
\hline ADI & 924 & 1993 & 2011 & Negado seguimento & Monocrática & Federal & Governador & Executivo Federal & Carmen Lucia & Operações de crédito \\
\hline ADI & 931 & 1993 & 2002 & Negado seguimento & Monocrática & Federal & Partido Político & Executivo Federal & Nelson Jobim & $\begin{array}{l}\text { Regulação da atividade } \\
\text { econômica }\end{array}$ \\
\hline ADI & 1007 & 1994 & 2006 & Procedente & Majoritária & Estadual & Associação/Confederação/Sindicato & \begin{tabular}{|l|} 
Legislativo \\
Estadual \\
\end{tabular} & Eros Grau & $\begin{array}{l}\text { Regulação da atividade } \\
\text { econômica }\end{array}$ \\
\hline ADI & 1042 & 1994 & 2009 & Procedente & Unânime & Estadual & Procurador-Geral da República & $\begin{array}{l}\text { Legislativo } \\
\text { Estadual }\end{array}$ & Gilmar Mendes & $\begin{array}{l}\text { Regulação da atividade } \\
\text { econômica }\end{array}$ \\
\hline ADI & 1081 & 1994 & 2004 & Negado seguimento & Monocrática & Federal & Associação/Confederação/Sindicato & Executivo Federal & Nelson Jobim & $\begin{array}{l}\text { Regulação da atividade } \\
\text { econômica }\end{array}$ \\
\hline ADI & 1131 & 1994 & 2002 & Improcedente & Unânime & Federal & Partido Político & Executivo Federal & Ilmar Galvão & $\begin{array}{l}\text { Empresa pública ou } \\
\text { sociedade de economia } \\
\text { mista }\end{array}$ \\
\hline ADI & 1155 & 1994 & 2001 & Negado seguimento & Monocrática & Federal & Associação/Confederação/Sindicato & Executivo Federal & Carlos Velloso & $\begin{array}{l}\text { Regulação da atividade } \\
\text { econômica }\end{array}$ \\
\hline ADI & 1245 & 1995 & 2005 & Procedente & Majoritária & Federal & Procurador-Geral da República & Executivo Estadual & Eros Grau & $\begin{array}{l}\text { Regulação da atividade } \\
\text { econômica }\end{array}$ \\
\hline ADI & 1263 & 1995 & 2001 & Negado seguimento & Monocrática & Federal & Partido Político & Executivo Federal & Néri da Silveira & $\begin{array}{l}\text { Programa de } \\
\text { desestatização }\end{array}$ \\
\hline ADI & 1278 & 1995 & 2007 & Improcedente & Unânime & Estadual & Governador & \begin{tabular}{|l|} 
Legislativo \\
Estadual \\
\end{tabular} & $\begin{array}{l}\text { Ricardo } \\
\text { Lewandowski }\end{array}$ & $\begin{array}{l}\text { Regulação da atividade } \\
\text { econômica }\end{array}$ \\
\hline ADI & 1312 & 1995 & 2004 & Negado seguimento & Monocrática & Federal & Partido Político & Executivo Federal & \begin{tabular}{|l|} 
Joaquim \\
Barbosa \\
\end{tabular} & $\begin{array}{l}\text { Regulação da atividade } \\
\text { econômica }\end{array}$ \\
\hline ADI & 1348 & 1995 & 2008 & Procedente & Unânime & Estadual & Governador & \begin{tabular}{|l} 
Legislativo \\
Estadual \\
\end{tabular} & Carmen Lucia & $\begin{array}{l}\text { Programa de } \\
\text { desestatização }\end{array}$ \\
\hline ADI & 1376 & 1995 & 1995 & Negado seguimento & Monocrática & Federal & Partido Político & Executivo Federal & Ilmar Galvão & Planos econômicos \\
\hline ADI & 1439 & 1996 & 1996 & Negado seguimento & Majoritária & Federal & Partido Político & Executivo Federal & Celso de Mello & Salário mínimo \\
\hline ADI & 1442 & 1996 & 2004 & Negado seguimento & Majoritária & Federal & Associação/Confederação/Sindicato & Executivo Federal & Celso de Mello & Salário mínimo \\
\hline ADI & 1447 & 1996 & 2004 & Negado seguimento & Monocrática & Federal & Associação/Confederação/Sindicato & Executivo Federal & Celso de Mello & Salário mínimo \\
\hline
\end{tabular}




\begin{tabular}{|c|c|c|c|c|c|c|c|c|c|c|}
\hline Tipo & Proc. & \begin{tabular}{r|} 
Ano \\
Ingresso
\end{tabular} & $\begin{array}{r}\text { Ano } \\
\text { final }\end{array}$ & Decisão & Colegiado & Origem & Autor & Requerido & Relator & Controvérsia \\
\hline ADI & 1458 & 1996 & 2001 & Negado seguimento & Monocrática & Federal & Associação/Confederação/Sindicato & Executivo Federal & $\begin{array}{l}\text { Sepulveda } \\
\text { Pertence }\end{array}$ & Salário mínimo \\
\hline ADI & 1468 & 1996 & 2004 & Negado seguimento & Monocrática & Federal & Partido Político & Executivo Federal & Celso de Mello & Salário mínimo \\
\hline ADI & 1472 & 1996 & 2002 & Procedente & Unânime & Estadual & Associação/Confederação/Sindicato & Executivo Estadual & Ilmar Galvão & $\begin{array}{l}\text { Regulação da atividade } \\
\text { econômica }\end{array}$ \\
\hline ADI & 1495 & 1996 & 2009 & Negado seguimento & Monocrática & Federal & Partido Político & Executivo Federal & $\begin{array}{l}\text { Ricardo } \\
\text { Lewandowski } \\
\end{array}$ & $\begin{array}{l}\text { Regulação da atividade } \\
\text { econômica }\end{array}$ \\
\hline ADI & 1549 & 1996 & 2002 & Negado seguimento & Monocrática & Estadual & Associação/Confederação/Sindicato & Executivo Estadual & Carlos Velloso & \begin{tabular}{|l|}
$\begin{array}{l}\text { Programa de } \\
\text { desestatização }\end{array}$ \\
\end{tabular} \\
\hline ADI & 1564 & 1997 & 2002 & Negado seguimento & Monocrática & Estadual & Partido Político & Executivo Estadual & Carlos Velloso & $\begin{array}{l}\begin{array}{l}\text { Programa de } \\
\text { desestatização }\end{array} \\
\end{array}$ \\
\hline ADI & 1584 & 1997 & 1999 & Negado seguimento & Monocrática & Federal & OAB & Executivo Federal & Ilmar Galvão & $\begin{array}{l}\text { Programa de } \\
\text { desestatização }\end{array}$ \\
\hline ADI & 1595 & 1997 & 2012 & Improcedente & Majoritária & Estadual & Associação/Confederação/Sindicato & $\begin{array}{l}\text { Legislativo } \\
\text { Estadual }\end{array}$ & Eros Grau & Consumidor \\
\hline ADI & 1597 & 1997 & 2006 & Negado seguimento & Monocrática & Federal & Partido Político & Executivo Federal & Gilmar Mendes & \begin{tabular}{|l} 
Programa de \\
desestatização
\end{tabular} \\
\hline ADI & 1623 & 1997 & 2011 & Procedente & Unânime & Estadual & Procurador-Geral da República & Executivo Estadual & $\begin{array}{l}\text { Joaquim } \\
\text { Barbosa } \\
\end{array}$ & $\begin{array}{l}\text { Regulação da atividade } \\
\text { econômica }\end{array}$ \\
\hline ADI & 1646 & 1997 & 2009 & Procedente & Majoritária & Estadual & Associação/Confederação/Sindicato & \begin{tabular}{|l|} 
Legislativo \\
Estadual \\
\end{tabular} & Gilmar Mendes & Consumidor \\
\hline ADI & 1650 & 1997 & 2007 & Negado seguimento & Monocrática & Federal & Associação/Confederação/Sindicato & Executivo Federal & $\begin{array}{l}\text { Sepulveda } \\
\text { Pertence }\end{array}$ & $\begin{array}{l}\text { Regulação da atividade } \\
\text { econômica }\end{array}$ \\
\hline $\mathrm{ADI}$ & 1675 & 1997 & 2003 & Negado seguimento & Unânime & Federal & Associação/Confederação/Sindicato & Executivo Federal & $\begin{array}{l}\text { Sepulveda } \\
\text { Pertence }\end{array}$ & $\begin{array}{l}\text { Regulação da atividade } \\
\text { econômica }\end{array}$ \\
\hline ADI & 1726 & 1997 & 2005 & Negado seguimento & Monocrática & Federal & Partido Político & Executivo Federal & Marco Aurélio & $\begin{array}{l}\text { Regulação da atividade } \\
\text { econômica }\end{array}$ \\
\hline ADI & 1733 & 1997 & 2004 & Negado seguimento & Monocrática & Federal & Governador & Legislativo Federal & Ellen Gracie & Operações de crédito \\
\hline ADI & 1734 & 1997 & 2004 & Negado seguimento & Monocrática & Federal & Governador & Legislativo Federal & Ellen Gracie & Operações de crédito \\
\hline $\mathrm{ADI}$ & 1735 & 1997 & 2004 & Negado seguimento & Monocrática & Federal & Governador & Legislativo Federal & Ellen Gracie & Operações de crédito \\
\hline ADI & 1736 & 1997 & 2004 & Negado seguimento & Monocrática & Federal & Governador & Legislativo Federal & Ellen Gracie & Operações de crédito \\
\hline
\end{tabular}




\begin{tabular}{|c|c|c|c|c|c|c|c|c|c|c|}
\hline Tipo & Proc. & $\begin{array}{r}\text { Ano } \\
\text { Ingresso }\end{array}$ & $\begin{array}{l}\text { Ano } \\
\text { final }\end{array}$ & Decisão & Colegiado & Origem & Autor & Requerido & Relator & Controvérsia \\
\hline $\mathrm{ADI}$ & 1737 & 1997 & 2004 & Negado seguimento & Monocrática & Federal & Governador & Legislativo Federal & Ellen Gracie & Operações de crédito \\
\hline ADI & 1738 & 1997 & 2004 & Negado seguimento & Monocrática & Federal & Governador & Legislativo Federal & Ellen Gracie & Operações de crédito \\
\hline ADI & 1739 & 1997 & 2004 & Negado seguimento & Monocrática & Federal & Governador & Legislativo Federal & Ellen Gracie & Operações de crédito \\
\hline ADI & 1740 & 1997 & 2004 & Negado seguimento & Monocrática & Federal & Governador & Legislativo Federal & Ellen Gracie & Operações de crédito \\
\hline $\mathrm{ADI}$ & 1741 & 1997 & 2004 & Negado seguimento & Monocrática & Federal & Governador & Legislativo Federal & Ellen Gracie & Operações de crédito \\
\hline ADI & 1742 & 1997 & 2004 & Negado seguimento & Monocrática & Federal & Governador & Legislativo Federal & Ellen Gracie & Operações de crédito \\
\hline $\mathrm{ADI}$ & 1743 & 1997 & 2004 & Negado seguimento & Monocrática & Federal & Governador & Legislativo Federal & Ellen Gracie & Operações de crédito \\
\hline ADI & 1744 & 1997 & 2004 & Negado seguimento & Monocrática & Federal & Governador & Legislativo Federal & Ellen Gracie & Operações de crédito \\
\hline $\mathrm{ADI}$ & 1745 & 1997 & 2004 & Negado seguimento & Monocrática & Federal & Governador & Legislativo Federal & Ellen Gracie & Operações de crédito \\
\hline ADI & 1761 & 1998 & 2004 & Negado seguimento & Monocrática & Federal & Governador & Legislativo Federal & Ellen Gracie & Operações de crédito \\
\hline $\mathrm{ADI}$ & 1769 & 1998 & 2004 & Negado seguimento & Monocrática & Federal & Governador & Legislativo Federal & Ellen Gracie & Operações de crédito \\
\hline ADI & 1796 & 1998 & 2004 & Negado seguimento & Monocrática & Federal & Governador & Legislativo Federal & Ellen Gracie & Operações de crédito \\
\hline ADI & 1830 & 1998 & 2002 & Negado seguimento & Unânime & Federal & Partido Político & Executivo Federal & Moreira Alves & Salário mínimo \\
\hline ADI & 1860 & 1998 & 2009 & Negado seguimento & Monocrática & Federal & Associação/Confederação/Sindicato & Executivo Federal & $\begin{array}{l}\text { Menezes } \\
\text { Direito } \\
\end{array}$ & $\begin{array}{l}\text { Piso salarial/remuneração } \\
\text { de categoria profissional }\end{array}$ \\
\hline ADI & 1863 & 1998 & 2007 & Improcedente & Unânime & Federal & Partido Político & Executivo Federal & Eros Grau & \begin{tabular}{|l|} 
Programa de \\
desestatização
\end{tabular} \\
\hline ADI & 1886 & 1998 & 1998 & Improcedente & Monocrática & Municipal & Associação/Confederação/Sindicato & $\begin{array}{l}\text { Executivo } \\
\text { Municipal } \\
\end{array}$ & Néri da Silveira & $\begin{array}{l}\text { Regulação da atividade } \\
\text { econômica }\end{array}$ \\
\hline ADI & 1918 & 1998 & 2001 & Procedente & Unânime & Estadual & Associação/Confederação/Sindicato & Executivo Estadual & \begin{tabular}{|l|} 
Maurício \\
Correa \\
\end{tabular} & $\begin{array}{l}\text { Regulação da atividade } \\
\text { econômica }\end{array}$ \\
\hline ADI & 1929 & 1998 & 1998 & Negado seguimento & Unânime & Federal & Associação/Confederação/Sindicato & Executivo Federal & Ilmar Galvão & $\begin{array}{l}\text { Cobrança de direitos } \\
\text { autorais por uma entidade } \\
\text { central }\end{array}$ \\
\hline ADI & 1980 & 1999 & 2009 & Improcedente & Unânime & Estadual & Governador & \begin{tabular}{|l|} 
Legislativo \\
Estadual \\
\end{tabular} & Cezar Peluso & Consumidor \\
\hline ADI & 1996 & 1999 & 1999 & Negado seguimento & Monocrática & Federal & Partido Político & Executivo Federal & Ilmar Galvão & Salário mínimo \\
\hline ADI & 1997 & 1999 & 1999 & Negado seguimento & Monocrática & Estadual & Associação/Confederação/Sindicato & Executivo Estadual & Marco Aurélio & $\begin{array}{l}\text { Regulação da atividade } \\
\text { econômica }\end{array}$ \\
\hline ADI & 1998 & 1999 & 2004 & Improcedente & Majoritária & Federal & Partido Político & Executivo Federal & $\begin{array}{l}\text { Maurício } \\
\text { Correa } \\
\end{array}$ & \begin{tabular}{|l} 
Empresa pública ou \\
sociedade de economia \\
mista
\end{tabular} \\
\hline
\end{tabular}




\begin{tabular}{|c|c|c|c|c|c|c|c|c|c|c|}
\hline Tipo & Proc. & \begin{tabular}{r|} 
Ano \\
Ingresso
\end{tabular} & $\begin{array}{r}\text { Ano } \\
\text { final }\end{array}$ & Decisão & Colegiado & Origem & Autor & Requerido & Relator & Controvérsia \\
\hline ADI & 2003 & 1999 & 1999 & Negado seguimento & Majoritária & Federal & Partido Político & Executivo Federal & Marco Aurélio & Planos econômicos \\
\hline ADI & 2038 & 1999 & 1999 & Negado seguimento & Majoritária & Estadual & Partido Político & Executivo Estadual & Nelson Jobim & $\begin{array}{l}\text { Programa de } \\
\text { desestatização }\end{array}$ \\
\hline ADI & 2054 & 1999 & 2003 & Improcedente & Majoritária & Federal & Partido Político & Executivo Federal & $\begin{array}{l}\text { Sepulveda } \\
\text { Pertence }\end{array}$ & $\begin{array}{l}\text { Cobrança de direitos } \\
\text { autorais por uma entidade } \\
\text { central }\end{array}$ \\
\hline ADI & 2162 & 2000 & 2000 & Negado seguimento & Unânime & Federal & Partido Político & Executivo Federal & Moreira Alves & Salário mínimo \\
\hline ADI & 2180 & 2000 & 2001 & Negado seguimento & Monocrática & Estadual & Associação/Confederação/Sindicato & Executivo Estadual & Néri da Silveira & $\begin{array}{l}\text { Regulação da atividade } \\
\text { econômica }\end{array}$ \\
\hline ADI & 2223 & 2000 & 2004 & Negado seguimento & Monocrática & Federal & Partido Político & Executivo Federal & \begin{tabular}{l|} 
Maurício \\
Correa
\end{tabular} & $\begin{array}{l}\text { Empresa pública ou } \\
\text { sociedade de economia } \\
\text { mista }\end{array}$ \\
\hline ADI & 2244 & 2000 & 2004 & Negado seguimento & Monocrática & Federal & Partido Político & Executivo Federal & $\begin{array}{l}\text { Maurício } \\
\text { Correa }\end{array}$ & $\begin{array}{l}\text { Empresa pública ou } \\
\text { sociedade de economia } \\
\text { mista }\end{array}$ \\
\hline ADI & 2252 & 2000 & 2000 & Negado seguimento & Monocrática & Federal & Associação/Confederação/Sindicato & Executivo Federal & $\begin{array}{l}\text { Sydney } \\
\text { Sanches }\end{array}$ & Operações de crédito \\
\hline ADI & 2326 & 2000 & 2000 & Negado seguimento & Monocrática & Federal & Associação/Confederação/Sindicato & Executivo Federal & $\begin{array}{l}\text { Sydney } \\
\text { Sanches }\end{array}$ & Planos econômicos \\
\hline ADI & 2327 & 2000 & 2003 & Procedente & Unânime & Estadual & Governador & \begin{tabular}{|l} 
Legislativo \\
Estadual
\end{tabular} & Gilmar Mendes & $\begin{array}{l}\text { Regulação da atividade } \\
\text { econômica }\end{array}$ \\
\hline ADI & 2334 & 2000 & 2003 & Improcedente & Unânime & Estadual & Associação/Confederação/Sindicato & Executivo Estadual & Gilmar Mendes & $\begin{array}{l}\text { Regulação da atividade } \\
\text { econômica }\end{array}$ \\
\hline ADI & 2358 & 2000 & 2000 & Negado seguimento & Monocrática & Estadual & Associação/Confederação/Sindicato & Executivo Estadual & Marco Aurélio & Salário mínimo \\
\hline ADI & 2359 & 2000 & 2006 & Improcedente & Majoritária & Estadual & Associação/Confederação/Sindicato & Executivo Estadual & Eros Grau & $\begin{array}{l}\text { Regulação da atividade } \\
\text { econômica }\end{array}$ \\
\hline $\mathrm{ADI}$ & 2396 & 2001 & 2003 & $\begin{array}{l}\text { Parcialmente } \\
\text { procedente }\end{array}$ & Unânime & Estadual & Governador & Executivo Estadual & Ellen Gracie & $\begin{array}{l}\text { Regulação da atividade } \\
\text { econômica }\end{array}$ \\
\hline ADI & 2401 & 2001 & 2004 & Negado seguimento & Monocrática & Estadual & Associação/Confederação/Sindicato & Executivo Estadual & Nelson Jobim & $\begin{array}{l}\text { Piso salarial/remuneração } \\
\text { de categoria profissional }\end{array}$ \\
\hline ADI & 2403 & 2001 & 2004 & Negado seguimento & Monocrática & Estadual & Associação/Confederação/Sindicato & Executivo Estadual & Eros Grau & $\begin{array}{l}\text { Piso salarial/remuneração } \\
\text { de categoria profissional }\end{array}$ \\
\hline
\end{tabular}




\begin{tabular}{|c|c|c|c|c|c|c|c|c|c|c|}
\hline Tipo & Proc. & $\begin{array}{r}\text { Ano } \\
\text { Ingresso }\end{array}$ & $\begin{array}{r}\text { Ano } \\
\text { final }\end{array}$ & Decisão & Colegiado & Origem & Autor & Requerido & Relator & Controvérsia \\
\hline ADI & 2438 & 2001 & 2001 & Negado seguimento & Monocrática & Estadual & Associação/Confederação/Sindicato & Executivo Estadual & Néri da Silveira & $\begin{array}{l}\text { Regulação da atividade } \\
\text { econômica }\end{array}$ \\
\hline ADI & 2443 & 2001 & 2014 & Procedente & Unânime & Estadual & Governador & \begin{tabular}{|l|} 
Legislativo \\
Estadual
\end{tabular} & Marco Aurélio & Consumidor \\
\hline ADI & 2448 & 2001 & 2003 & Procedente & Majoritária & Estadual & Associação/Confederação/Sindicato & $\begin{array}{l}\text { Legislativo } \\
\text { Estadual }\end{array}$ & \begin{tabular}{|l|} 
Sydney \\
Sanches
\end{tabular} & $\begin{array}{l}\text { Regulação da atividade } \\
\text { econômica }\end{array}$ \\
\hline ADI & 2450 & 2001 & 2002 & Negado seguimento & Monocrática & Estadual & Governador & $\begin{array}{l}\text { Legislativo } \\
\text { Estadual }\end{array}$ & Carlos Velloso & $\begin{array}{l}\text { Regulação da atividade } \\
\text { econômica }\end{array}$ \\
\hline ADI & 2463 & 2001 & 2007 & Negado seguimento & Monocrática & Federal & Partido Político & Executivo Federal & \begin{tabular}{|l|} 
Maurício \\
Correa \\
\end{tabular} & $\begin{array}{l}\text { Regulação da atividade } \\
\text { econômica }\end{array}$ \\
\hline ADI & 2470 & 2001 & 2014 & Negado seguimento & Monocrática & Federal & Associação/Confederação/Sindicato & Executivo Federal & \begin{tabular}{|l|} 
Roberto \\
Barroso
\end{tabular} & $\begin{array}{l}\text { Regulação da atividade } \\
\text { econômica }\end{array}$ \\
\hline ADI & 2552 & 2001 & 2001 & Negado seguimento & Monocrática & Estadual & Partido Político & Executivo Estadual & \begin{tabular}{|l|} 
Maurício \\
Correa \\
\end{tabular} & $\begin{array}{l}\begin{array}{l}\text { Programa de } \\
\text { desestatização }\end{array} \\
\end{array}$ \\
\hline ADI & 2560 & 2001 & 2002 & Negado seguimento & Monocrática & Estadual & Associação/Confederação/Sindicato & \begin{tabular}{|l|} 
Legislativo \\
Estadual \\
\end{tabular} & Carlos Velloso & $\begin{array}{l}\text { Regulação da atividade } \\
\text { econômica }\end{array}$ \\
\hline ADI & 2591 & 2001 & 2007 & Improcedente & Majoritária & Federal & Associação/Confederação/Sindicato & Executivo Federal & Eros Grau & Consumidor \\
\hline ADI & 2606 & 2002 & 2002 & Procedente & Unânime & Estadual & Associação/Confederação/Sindicato & Executivo Estadual & \begin{tabular}{|l|} 
Maurício \\
Correa \\
\end{tabular} & Trânsito e transporte \\
\hline ADI & 2615 & 2002 & 2015 & Procedente & Majoritária & Estadual & Governador & \begin{tabular}{|l} 
Legislativo \\
Estadual
\end{tabular} & Eros Grau & Consumidor \\
\hline ADI & 2623 & 2002 & 2002 & Negado seguimento & Monocrática & Estadual & Associação/Confederação/Sindicato & \begin{tabular}{|l|} 
Legislativo \\
Estadual
\end{tabular} & \begin{tabular}{|l|} 
Maurício \\
Correa \\
\end{tabular} & $\begin{array}{l}\text { Regulação da atividade } \\
\text { econômica }\end{array}$ \\
\hline ADI & 2656 & 2002 & 2003 & $\begin{array}{l}\text { Parcialmente } \\
\text { procedente }\end{array}$ & Unânime & Estadual & Governador & Executivo Estadual & \begin{tabular}{|l|} 
Maurício \\
Correa
\end{tabular} & $\begin{array}{l}\text { Regulação da atividade } \\
\text { econômica }\end{array}$ \\
\hline ADI & 2690 & 2002 & 2006 & Procedente & Unânime & Estadual & Governador & \begin{tabular}{|l|} 
Legislativo \\
Estadual \\
\end{tabular} & Gilmar Mendes & $\begin{array}{l}\text { Sistema de consórcios e } \\
\text { sorteios }\end{array}$ \\
\hline ADI & 2697 & 2002 & 2004 & Negado seguimento & Monocrática & Estadual & Associação/Confederação/Sindicato & Executivo Estadual & Ellen Gracie & $\begin{array}{l}\text { Regulação da atividade } \\
\text { econômica }\end{array}$ \\
\hline ADI & 2800 & 2003 & 2011 & $\begin{array}{l}\text { Parcialmente } \\
\text { procedente }\end{array}$ & Unânime & Estadual & Governador & \begin{tabular}{|l} 
Legislativo \\
Estadual
\end{tabular} & $\begin{array}{l}\text { Maurício } \\
\text { Correa }\end{array}$ & $\begin{array}{l}\text { Regulação da atividade } \\
\text { econômica }\end{array}$ \\
\hline ADI & 2818 & 2003 & 2013 & Improcedente & Unânime & Estadual & Governador & $\begin{array}{l}\text { Legislativo } \\
\text { Estadual }\end{array}$ & Dias Toffoli & $\begin{array}{l}\text { Regulação da atividade } \\
\text { econômica }\end{array}$ \\
\hline
\end{tabular}




\begin{tabular}{|c|c|c|c|c|c|c|c|c|c|c|}
\hline Tipo & Proc. & \begin{tabular}{r|} 
Ano \\
Ingresso
\end{tabular} & $\begin{array}{r}\text { Ano } \\
\text { final }\end{array}$ & Decisão & Colegiado & Origem & Autor & Requerido & Relator & Controvérsia \\
\hline ADI & 2832 & 2003 & 2008 & $\begin{array}{l}\text { Parcialmente } \\
\text { procedente }\end{array}$ & Majoritária & Estadual & Associação/Confederação/Sindicato & Executivo Estadual & $\begin{array}{l}\text { Ricardo } \\
\text { Lewandowski }\end{array}$ & $\begin{array}{l}\text { Regulação da atividade } \\
\text { econômica }\end{array}$ \\
\hline ADI & 2847 & 2003 & 2004 & Procedente & Majoritária & Estadual & Procurador-Geral da República & Executivo Estadual & Carlos Velloso & $\begin{array}{l}\text { Sistema de consórcios e } \\
\text { sorteios }\end{array}$ \\
\hline ADI & 2848 & 2003 & 2016 & Negado seguimento & Monocrática & Estadual & Associação/Confederação/Sindicato & $\begin{array}{l}\text { Legislativo } \\
\text { Estadual }\end{array}$ & Teori Zavascki & Consumidor \\
\hline ADI & 2866 & 2003 & 2010 & \begin{tabular}{|l|}
$\begin{array}{l}\text { Parcialmente } \\
\text { procedente }\end{array}$ \\
\end{tabular} & Unânime & Estadual & Associação/Confederação/Sindicato & $\begin{array}{l}\text { Legislativo } \\
\text { Estadual }\end{array}$ & Gilmar Mendes & $\begin{array}{l}\text { Regulação da atividade } \\
\text { econômica }\end{array}$ \\
\hline ADI & 2928 & 2003 & 2005 & Procedente & Majoritária & Estadual & Procurador-Geral da República & $\begin{array}{l}\text { Legislativo } \\
\text { Estadual }\end{array}$ & Eros Grau & Trânsito e transporte \\
\hline ADI & 2948 & 2003 & 2005 & Procedente & Majoritária & Estadual & Procurador-Geral da República & Executivo Estadual & Eros Grau & $\begin{array}{l}\text { Sistema de consórcios e } \\
\text { sorteios }\end{array}$ \\
\hline ADI & 2950 & 2003 & 2007 & Procedente & Unânime & Estadual & Procurador-Geral da República & Executivo Estadual & Marco Aurélio & $\begin{array}{l}\text { Sistema de consórcios e } \\
\text { sorteios }\end{array}$ \\
\hline ADI & 2995 & 2003 & 2006 & Procedente & Majoritária & Estadual & Procurador-Geral da República & Executivo Estadual & Celso de Mello & $\begin{array}{l}\text { Sistema de consórcios e } \\
\text { sorteios }\end{array}$ \\
\hline ADI & 2996 & 2003 & 2006 & Procedente & Majoritária & Estadual & Procurador-Geral da República & Executivo Estadual & \begin{tabular}{|l|l} 
Sepulveda \\
Pertence
\end{tabular} & $\begin{array}{l}\text { Sistema de consórcios e } \\
\text { sorteios }\end{array}$ \\
\hline ADI & 3001 & 2003 & 2010 & $\begin{array}{l}\begin{array}{l}\text { Parcialmente } \\
\text { procedente }\end{array} \\
\end{array}$ & Unânime & Estadual & Governador & $\begin{array}{l}\text { Legislativo } \\
\text { Estadual } \\
\end{array}$ & Gilmar Mendes & $\begin{array}{l}\text { Regulação da atividade } \\
\text { econômica }\end{array}$ \\
\hline ADI & 3004 & 2003 & 2013 & Negado seguimento & Monocrática & Estadual & Procurador-Geral da República & $\begin{array}{l}\text { Legislativo } \\
\text { Estadual }\end{array}$ & $\begin{array}{l}\text { Joaquim } \\
\text { Barbosa }\end{array}$ & $\begin{array}{l}\text { Sistema de consórcios e } \\
\text { sorteios }\end{array}$ \\
\hline ADI & 3011 & 2003 & 2004 & Negado seguimento & Monocrática & Federal & Partido Político & Executivo Federal & Ellen Gracie & $\begin{array}{l}\text { Regulação da atividade } \\
\text { econômica }\end{array}$ \\
\hline ADI & 3014 & 2003 & 2004 & Negado seguimento & Monocrática & Federal & Associação/Confederação/Sindicato & Executivo Federal & Ellen Gracie & $\begin{array}{l}\text { Regulação da atividade } \\
\text { econômica }\end{array}$ \\
\hline ADI & 3017 & 2003 & 2004 & Negado seguimento & Monocrática & Federal & Procurador-Geral da República & Executivo Federal & Ellen Gracie & $\begin{array}{l}\text { Regulação da atividade } \\
\text { econômica }\end{array}$ \\
\hline $\mathrm{ADI}$ & 3035 & 2003 & 2005 & Procedente & Unânime & Estadual & Partido Político & Executivo Estadual & Gilmar Mendes & $\begin{array}{l}\text { Regulação da atividade } \\
\text { econômica }\end{array}$ \\
\hline ADI & 3036 & 2003 & 2004 & Negado seguimento & Monocrática & Federal & Partido Político & Executivo Federal & Ellen Gracie & $\begin{array}{l}\text { Regulação da atividade } \\
\text { econômica }\end{array}$ \\
\hline
\end{tabular}




\begin{tabular}{|c|c|c|c|c|c|c|c|c|c|c|}
\hline Tipo & Proc. & $\begin{array}{r}\text { Ano } \\
\text { Ingresso }\end{array}$ & $\begin{array}{r}\text { Ano } \\
\text { final }\end{array}$ & Decisão & Colegiado & Origem & Autor & Requerido & Relator & Controvérsia \\
\hline ADI & 3054 & 2003 & 2005 & Procedente & Unânime & Estadual & Governador & Executivo Estadual & Gilmar Mendes & $\begin{array}{l}\text { Regulação da atividade } \\
\text { econômica }\end{array}$ \\
\hline ADI & 3060 & 2003 & 2007 & Procedente & Majoritária & Estadual & Procurador-Geral da República & Executivo Estadual & \begin{tabular}{|l|} 
Sepulveda \\
Pertence
\end{tabular} & $\begin{array}{l}\text { Sistema de consórcios e } \\
\text { sorteios }\end{array}$ \\
\hline ADI & 3063 & 2003 & 2006 & Procedente & Majoritária & Estadual & Procurador-Geral da República & Executivo Estadual & Cezar Peluso & \begin{tabular}{|l|l|}
$\begin{array}{l}\text { Sistema de consórcios e } \\
\text { sorteios }\end{array}$ \\
\end{tabular} \\
\hline ADI & 3101 & 2004 & 2005 & Negado seguimento & Monocrática & Federal & Partido Político & Executivo Federal & Celso de Mello & $\begin{array}{l}\text { Empresa pública ou } \\
\text { sociedade de economia } \\
\text { mista }\end{array}$ \\
\hline ADI & 3113 & 2004 & 2005 & Negado seguimento & Monocrática & Estadual & Governador & \begin{tabular}{|l|} 
Legislativo \\
Estadual \\
\end{tabular} & Eros Grau & $\begin{array}{l}\begin{array}{l}\text { Regulação da atividade } \\
\text { econômica }\end{array} \\
\end{array}$ \\
\hline ADI & 3139 & 2004 & 2006 & Negado seguimento & Monocrática & Estadual & Procurador-Geral da República & Executivo Estadual & $\begin{array}{l}\text { Ricardo } \\
\text { Lewandowski }\end{array}$ & $\begin{array}{l}\text { Regulação da atividade } \\
\text { econômica }\end{array}$ \\
\hline ADI & 3147 & 2004 & 2006 & Procedente & Majoritária & Estadual & Procurador-Geral da República & Executivo Estadual & Ayres Britto & $\begin{array}{l}\begin{array}{l}\text { Sistema de consórcios e } \\
\text { sorteios }\end{array} \\
\end{array}$ \\
\hline ADI & 3148 & 2004 & 2006 & Procedente & Majoritária & Estadual & Procurador-Geral da República & Executivo Estadual & Celso de Mello & $\begin{array}{l}\text { Sistema de consórcios e } \\
\text { sorteios }\end{array}$ \\
\hline ADI & 3153 & 2004 & 2004 & Negado seguimento & Monocrática & Federal & Associação/Confederação/Sindicato & Executivo Federal & Celso de Mello & $\begin{array}{l}\text { Regulação da atividade } \\
\text { econômica }\end{array}$ \\
\hline ADI & 3183 & 2004 & 2006 & Procedente & Majoritária & Estadual & Procurador-Geral da República & Executivo Estadual & \begin{tabular}{|l|} 
Joaquim \\
Barbosa \\
\end{tabular} & $\begin{array}{l}\text { Sistema de consórcios e } \\
\text { sorteios }\end{array}$ \\
\hline ADI & 3189 & 2004 & 2006 & Procedente & Unânime & Estadual & Procurador-Geral da República & Executivo Estadual & Celso de Mello & $\begin{array}{l}\text { Sistema de consórcios e } \\
\text { sorteios }\end{array}$ \\
\hline ADI & 3241 & 2004 & 2004 & Negado seguimento & Monocrática & Federal & Partido Político & Executivo Federal & Ayres Britto & $\begin{array}{l}\text { Regulação da atividade } \\
\text { econômica }\end{array}$ \\
\hline ADI & 3254 & 2004 & 2005 & Procedente & Unânime & Estadual & Governador & \begin{tabular}{|l|} 
Legislativo \\
Estadual \\
\end{tabular} & Ellen Gracie & Trânsito e transporte \\
\hline ADI & 3259 & 2004 & 2005 & Procedente & Majoritária & Estadual & Procurador-Geral da República & Executivo Estadual & Eros Grau & $\begin{array}{l}\text { Sistema de consórcios e } \\
\text { sorteios }\end{array}$ \\
\hline ADI & 3277 & 2004 & 2007 & Procedente & Majoritária & Estadual & Procurador-Geral da República & Executivo Estadual & \begin{tabular}{|l|} 
Sepulveda \\
Pertence
\end{tabular} & $\begin{array}{l}\text { Sistema de consórcios e } \\
\text { sorteios }\end{array}$ \\
\hline ADI & 3293 & 2004 & 2006 & Procedente & Majoritária & Estadual & Procurador-Geral da República & \begin{tabular}{|l|} 
Legislativo \\
Estadual \\
\end{tabular} & Celso de Mello & $\begin{array}{l}\text { Sistema de consórcios e } \\
\text { sorteios }\end{array}$ \\
\hline ADI & 3322 & 2004 & 2011 & Procedente & Unânime & Estadual & Governador & $\begin{array}{l}\text { Legislativo } \\
\text { Estadual }\end{array}$ & Gilmar Mendes & Consumidor \\
\hline
\end{tabular}




\begin{tabular}{|c|c|c|c|c|c|c|c|c|c|c|}
\hline Tipo & Proc. & $\begin{array}{r}\text { Ano } \\
\text { Ingresso } \\
\end{array}$ & $\begin{array}{r}\text { Ano } \\
\text { final }\end{array}$ & Decisão & Colegiado & Origem & Autor & Requerido & Relator & Controvérsia \\
\hline $\mathrm{ADI}$ & 3328 & 2004 & 2004 & Negado seguimento & Monocrática & Federal & Partido Político & Executivo Federal & Celso de Mello & $\begin{array}{l}\text { Regulação da atividade } \\
\text { econômica }\end{array}$ \\
\hline ADI & 3343 & 2004 & 2011 & Procedente & Majoritária & Estadual & Governador & $\begin{array}{l}\text { Legislativo } \\
\text { Estadual }\end{array}$ & Luiz Fux & Consumidor \\
\hline ADI & 3368 & 2004 & 2005 & Negado seguimento & Monocrática & Federal & Procurador-Geral da República & Executivo Estadual & Eros Grau & $\begin{array}{l}\text { Sistema de consórcios e } \\
\text { sorteios }\end{array}$ \\
\hline ADI & 3384 & 2005 & 2008 & Negado seguimento & Monocrática & Estadual & Governador & $\begin{array}{l}\text { Legislativo } \\
\text { Estadual }\end{array}$ & $\begin{array}{l}\text { Menezes } \\
\text { Direito } \\
\end{array}$ & $\begin{array}{l}\text { Regulação da atividade } \\
\text { econômica }\end{array}$ \\
\hline $\mathrm{ADI}$ & 3403 & 2005 & 2007 & Procedente & Unânime & Estadual & Governador & $\begin{array}{l}\text { Legislativo } \\
\text { Estadual }\end{array}$ & $\begin{array}{l}\text { Joaquim } \\
\text { Barbosa }\end{array}$ & Consumidor \\
\hline ADI & 3457 & 2005 & 2005 & Negado seguimento & Monocrática & Estadual & Governador & $\begin{array}{l}\text { Legislativo } \\
\text { Estadual }\end{array}$ & Cezar Peluso & Consumidor \\
\hline ADI & 3471 & 2005 & 2005 & Negado seguimento & Monocrática & Federal & Partido Político & Executivo Federal & Ellen Gracie & $\begin{array}{l}\text { Empresa pública ou } \\
\text { sociedade de economia } \\
\text { mista }\end{array}$ \\
\hline ADI & 3511 & 2005 & 2005 & Negado seguimento & Monocrática & Federal & Associação/Confederação/Sindicato & Executivo Federal & Ellen Gracie & $\begin{array}{l}\text { Empresa pública ou } \\
\text { sociedade de economia } \\
\text { mista }\end{array}$ \\
\hline ADI & 3513 & 2005 & 2005 & Negado seguimento & Monocrática & Estadual & Governador & $\begin{array}{l}\text { Legislativo } \\
\text { Estadual } \\
\end{array}$ & Ellen Gracie & $\begin{array}{l}\text { Regulação da atividade } \\
\text { econômica }\end{array}$ \\
\hline ADI & 3515 & 2005 & 2011 & Procedente & Unânime & Estadual & Governador & $\begin{array}{l}\text { Legislativo } \\
\text { Estadual }\end{array}$ & Cezar Peluso & Operações de crédito \\
\hline ADI & 3533 & 2005 & 2006 & Procedente & Majoritária & Estadual & Governador & $\begin{array}{l}\text { Legislativo } \\
\text { Estadual }\end{array}$ & Eros Grau & Consumidor \\
\hline ADI & 3556 & 2005 & 2007 & Negado seguimento & Monocrática & Estadual & Governador & $\begin{array}{l}\text { Legislativo } \\
\text { Estadual }\end{array}$ & Ayres Britto & $\begin{array}{l}\text { Regulação da atividade } \\
\text { econômica }\end{array}$ \\
\hline ADI & 3558 & 2005 & 2011 & Procedente & Unânime & Estadual & Procurador-Geral da República & $\begin{array}{l}\text { Legislativo } \\
\text { Estadual }\end{array}$ & Carmen Lucia & Consumidor \\
\hline ADI & 3668 & 2006 & 2007 & Procedente & Unânime & Estadual & Governador & $\begin{array}{l}\text { Legislativo } \\
\text { Estadual }\end{array}$ & Gilmar Mendes & Operações de crédito \\
\hline ADI & 3679 & 2006 & 2007 & Procedente & Unânime & Estadual & Procurador-Geral da República & $\begin{array}{l}\text { Legislativo } \\
\text { Estadual }\end{array}$ & $\begin{array}{l}\text { Sepulveda } \\
\text { Pertence }\end{array}$ & Trânsito e transporte \\
\hline
\end{tabular}




\begin{tabular}{|c|c|c|c|c|c|c|c|c|c|c|}
\hline Tipo & Proc. & $\begin{array}{r}\text { Ano } \\
\text { Ingresso }\end{array}$ & $\begin{array}{r}\text { Ano } \\
\text { final }\end{array}$ & Decisão & Colegiado & Origem & Autor & Requerido & Relator & Controvérsia \\
\hline $\mathrm{ADI}$ & 3691 & 2006 & 2007 & Procedente & Majoritária & Estadual & Associação/Confederação/Sindicato & Executivo Estadual & Gilmar Mendes & $\begin{array}{l}\text { Regulação da atividade } \\
\text { econômica }\end{array}$ \\
\hline ADI & 3710 & 2006 & 2007 & Procedente & Majoritária & Estadual & Associação/Confederação/Sindicato & $\begin{array}{l}\text { Legislativo } \\
\text { Estadual }\end{array}$ & \begin{tabular}{|l|} 
Joaquim \\
Barbosa
\end{tabular} & $\begin{array}{l}\text { Regulação da atividade } \\
\text { econômica }\end{array}$ \\
\hline ADI & 3729 & 2006 & 2007 & Procedente & Majoritária & Estadual & Governador & $\begin{array}{l}\text { Legislativo } \\
\text { Estadual }\end{array}$ & Gilmar Mendes & Consumidor \\
\hline ADI & 3731 & 2006 & 2009 & Negado seguimento & Monocrática & Estadual & Associação/Confederação/Sindicato & Executivo Estadual & Cezar Peluso & $\begin{array}{l}\text { Regulação da atividade } \\
\text { econômica }\end{array}$ \\
\hline ADI & 3732 & 2006 & 2007 & Negado seguimento & Monocrática & Estadual & Associação/Confederação/Sindicato & Conselhos & \begin{tabular}{|l|} 
Joaquim \\
Barbosa
\end{tabular} & $\begin{array}{l}\text { Regulação da atividade } \\
\text { econômica }\end{array}$ \\
\hline ADI & 3749 & 2006 & 2011 & Negado seguimento & Monocrática & Estadual & Associação/Confederação/Sindicato & Executivo Estadual & Ayres Britto & $\begin{array}{l}\text { Piso salarial/remuneração } \\
\text { de categoria profissional }\end{array}$ \\
\hline $\mathrm{ADI}$ & 3844 & 2007 & 2009 & Negado seguimento & Monocrática & Estadual & Governador & $\begin{array}{l}\text { Legislativo } \\
\text { Estadual }\end{array}$ & Celso de Mello & Trânsito e transporte \\
\hline ADI & 3846 & 2007 & 2010 & $\begin{array}{l}\text { Parcialmente } \\
\text { procedente }\end{array}$ & Unânime & Estadual & Associação/Confederação/Sindicato & Executivo Estadual & Gilmar Mendes & $\begin{array}{l}\text { Regulação da atividade } \\
\text { econômica }\end{array}$ \\
\hline ADI & 3847 & 2007 & 2012 & Procedente & Majoritária & Estadual & Governador & $\begin{array}{l}\text { Legislativo } \\
\text { Estadual }\end{array}$ & Gilmar Mendes & Consumidor \\
\hline ADI & 3850 & 2007 & 2007 & Negado seguimento & Unânime & Estadual & Associação/Confederação/Sindicato & $\begin{array}{l}\text { Legislativo } \\
\text { Estadual }\end{array}$ & \begin{tabular}{|l|} 
Sepulveda \\
Pertence
\end{tabular} & $\begin{array}{l}\text { Sistema de consórcios e } \\
\text { sorteios }\end{array}$ \\
\hline ADI & 3852 & 2007 & 2016 & Procedente & Unânime & Estadual & Governador & $\begin{array}{l}\text { Legislativo } \\
\text { Estadual }\end{array}$ & Dias Toffoli & $\begin{array}{l}\text { Regulação da atividade } \\
\text { econômica }\end{array}$ \\
\hline ADI & 3860 & 2007 & 2008 & Negado seguimento & Monocrática & Estadual & Procurador-Geral da República & $\begin{array}{l}\text { Legislativo } \\
\text { Estadual }\end{array}$ & \begin{tabular}{|l|} 
Ricardo \\
Lewandowski
\end{tabular} & Trânsito e transporte \\
\hline ADI & 3895 & 2007 & 2008 & Procedente & Majoritária & Estadual & Governador & $\begin{array}{l}\text { Legislativo } \\
\text { Estadual }\end{array}$ & \begin{tabular}{|l|} 
Menezes \\
Direito \\
\end{tabular} & $\begin{array}{l}\text { Sistema de consórcios e } \\
\text { sorteios }\end{array}$ \\
\hline ADI & 3900 & 2007 & 2010 & Negado seguimento & Majoritária & Estadual & Associação/Confederação/Sindicato & Executivo Estadual & Carmen Lucia & $\begin{array}{l}\text { Regulação da atividade } \\
\text { econômica }\end{array}$ \\
\hline $\mathrm{ADI}$ & 3905 & 2007 & 2011 & Procedente & Majoritária & Estadual & Associação/Confederação/Sindicato & $\begin{array}{l}\text { Legislativo } \\
\text { Estadual }\end{array}$ & Carmen Lucia & Consumidor \\
\hline ADI & 3906 & 2007 & 2007 & Negado seguimento & Monocrática & Federal & Associação/Confederação/Sindicato & Executivo Federal & \begin{tabular}{|l|} 
Sepulveda \\
Pertence
\end{tabular} & $\begin{array}{l}\text { Regulação da atividade } \\
\text { econômica }\end{array}$ \\
\hline $\mathrm{ADI}$ & 3919 & 2007 & 2012 & Negado seguimento & Monocrática & Estadual & Procurador-Geral da República & Executivo Estadual & Gilmar Mendes & $\begin{array}{l}\text { Sistema de consórcios e } \\
\text { sorteios }\end{array}$ \\
\hline
\end{tabular}




\begin{tabular}{|c|c|c|c|c|c|c|c|c|c|c|}
\hline Tipo & Proc. & $\begin{array}{r}\text { Ano } \\
\text { Ingresso }\end{array}$ & $\begin{array}{l}\text { Ano } \\
\text { final }\end{array}$ & Decisão & Colegiado & Origem & Autor & Requerido & Relator & Controvérsia \\
\hline ADI & 3933 & 2007 & 2007 & Improcedente & Monocrática & Federal & Associação/Confederação/Sindicato & Executivo Federal & Cezar Peluso & $\begin{array}{l}\text { Regulação da atividade } \\
\text { econômica }\end{array}$ \\
\hline ADI & 3939 & 2007 & 2010 & Negado seguimento & Monocrática & Estadual & Governador & Executivo Federal & Carmen Lucia & $\begin{array}{l}\text { Regulação da atividade } \\
\text { econômica }\end{array}$ \\
\hline ADI & 3947 & 2007 & 2016 & Negado seguimento & Monocrática & Estadual & Governador & Conselhos & Carmen Lucia & $\begin{array}{l}\text { Regulação da atividade } \\
\text { econômica }\end{array}$ \\
\hline ADI & 3959 & 2007 & 2016 & Procedente & Unânime & Estadual & Governador & \begin{tabular}{|l|} 
Legislativo \\
Estadual \\
\end{tabular} & \begin{tabular}{|l|} 
Roberto \\
Barroso \\
\end{tabular} & Consumidor \\
\hline ADI & 3960 & 2007 & 2014 & Negado seguimento & Monocrática & Estadual & Governador & \begin{tabular}{|l|} 
Legislativo \\
Estadual \\
\end{tabular} & Carmen Lucia & Trânsito e transporte \\
\hline ADI & 3985 & 2007 & 2008 & Negado seguimento & Monocrática & Estadual & Governador & Executivo Federal & Gilmar Mendes & \begin{tabular}{|l|} 
Programa de \\
desestatização
\end{tabular} \\
\hline ADI & 4005 & 2008 & 2010 & Negado seguimento & Monocrática & Federal & Partido Político & Executivo Federal & Carmen Lucia & Operações de crédito \\
\hline ADI & 4040 & 2008 & 2013 & Negado seguimento & Unânime & Federal & Partido Político & Executivo Federal & Carmen Lucia & $\begin{array}{l}\text { Programa de } \\
\text { desestatização }\end{array}$ \\
\hline ADI & 4090 & 2008 & 2009 & Negado seguimento & Monocrática & Estadual & Associação/Confederação/Sindicato & Executivo Estadual & Luiz Fux & $\begin{array}{l}\text { Regulação da atividade } \\
\text { econômica }\end{array}$ \\
\hline ADI & 4095 & 2008 & 2008 & Negado seguimento & Monocrática & Estadual & Associação/Confederação/Sindicato & Executivo Estadual & Ellen Gracie & $\begin{array}{l}\text { Regulação da atividade } \\
\text { econômica }\end{array}$ \\
\hline ADI & 4347 & 2009 & 2009 & Negado seguimento & Monocrática & Federal & Associação/Confederação/Sindicato & Executivo Federal & Eros Grau & $\begin{array}{l}\text { Regulação da atividade } \\
\text { econômica }\end{array}$ \\
\hline ADI & 4364 & 2010 & 2011 & $\begin{array}{l}\text { Parcialmente } \\
\text { procedente }\end{array}$ & Unânime & Estadual & Associação/Confederação/Sindicato & Executivo Estadual & Dias Toffoli & $\begin{array}{l}\text { Piso salarial/remuneração } \\
\text { de categoria profissional }\end{array}$ \\
\hline ADI & 4369 & 2010 & 2014 & Procedente & Unânime & Estadual & Associação/Confederação/Sindicato & $\begin{array}{l}\text { Legislativo } \\
\text { Estadual } \\
\end{array}$ & Marco Aurélio & Consumidor \\
\hline ADI & 4375 & 2010 & 2011 & $\begin{array}{l}\text { Parcialmente } \\
\text { procedente }\end{array}$ & Unânime & Estadual & Associação/Confederação/Sindicato & Executivo Estadual & Dias Toffoli & $\begin{array}{l}\text { Piso salarial/remuneração } \\
\text { de categoria profissional }\end{array}$ \\
\hline ADI & 4391 & 2010 & 2011 & Procedente & Majoritária & Estadual & Associação/Confederação/Sindicato & Executivo Estadual & Dias Toffoli & $\begin{array}{l}\text { Piso salarial/remuneração } \\
\text { de categoria profissional }\end{array}$ \\
\hline ADI & 4432 & 2010 & 2011 & Improcedente & Majoritária & Estadual & Associação/Confederação/Sindicato & Executivo Estadual & Dias Toffoli & $\begin{array}{l}\text { Piso salarial/remuneração } \\
\text { de categoria profissional }\end{array}$ \\
\hline ADI & 4478 & 2010 & 2011 & Procedente & Majoritária & Estadual & Associação/Confederação/Sindicato & $\begin{array}{l}\text { Legislativo } \\
\text { Estadual }\end{array}$ & Luiz Fux & Consumidor \\
\hline
\end{tabular}




\begin{tabular}{|c|c|c|c|c|c|c|c|c|c|c|}
\hline Tipo & Proc. & \begin{tabular}{r|} 
Ano \\
Ingresso
\end{tabular} & $\begin{array}{l}\text { Ano } \\
\text { final }\end{array}$ & Decisão & Colegiado & Origem & Autor & Requerido & Relator & Controvérsia \\
\hline ADI & 4568 & 2011 & 2011 & Improcedente & Majoritária & Federal & Partido Político & Executivo Federal & Carmen Lucia & Salário mínimo \\
\hline ADI & 4588 & 2011 & 2012 & Negado seguimento & Monocrática & Federal & Partido Político & Executivo Federal & $\begin{array}{l}\text { Ricardo } \\
\text { Lewandowski }\end{array}$ & $\begin{array}{l}\text { Empresa pública ou } \\
\text { sociedade de economia } \\
\text { mista }\end{array}$ \\
\hline ADI & 4603 & 2011 & 2016 & Procedente & Unânime & Estadual & Associação/Confederação/Sindicato & $\begin{array}{l}\text { Legislativo } \\
\text { Estadual }\end{array}$ & Dias Toffoli & Consumidor \\
\hline ADI & 4701 & 2011 & 2014 & Procedente & Unânime & Estadual & Associação/Confederação/Sindicato & $\begin{array}{l}\text { Legislativo } \\
\text { Estadual }\end{array}$ & \begin{tabular}{|l|} 
Roberto \\
Barroso
\end{tabular} & Consumidor \\
\hline $\mathrm{ADI}$ & 4862 & 2012 & 2017 & Procedente & Majoritária & Estadual & Associação/Confederação/Sindicato & $\begin{array}{l}\text { Legislativo } \\
\text { Estadual }\end{array}$ & Gilmar Mendes & $\begin{array}{l}\text { Regulação da atividade } \\
\text { econômica }\end{array}$ \\
\hline ADI & 4864 & 2012 & 2012 & Negado seguimento & Monocrática & Municipal & Associação/Confederação/Sindicato & $\begin{array}{l}\text { Executivo } \\
\text { Municipal }\end{array}$ & Marco Aurélio & $\begin{array}{l}\text { Regulação da atividade } \\
\text { econômica }\end{array}$ \\
\hline ADI & 4875 & 2012 & 2014 & Negado seguimento & Monocrática & Estadual & Associação/Confederação/Sindicato & $\begin{array}{l}\text { Legislativo } \\
\text { Estadual }\end{array}$ & Celso de Mello & Consumidor \\
\hline ADI & 4952 & 2013 & 2014 & Negado seguimento & Monocrática & Estadual & Procurador-Geral da República & Executivo Estadual & Luiz Fux & $\begin{array}{l}\text { Regulação da atividade } \\
\text { econômica }\end{array}$ \\
\hline ADI & 5056 & 2013 & 2014 & Negado seguimento & Majoritária & Estadual & Associação/Confederação/Sindicato & Executivo Estadual & Celso de Mello & Consumidor \\
\hline ADI & 5141 & 2014 & 2014 & Negado seguimento & Monocrática & Federal & Associação/Confederação/Sindicato & Executivo Federal & Celso de Mello & Consumidor \\
\hline ADI & 5504 & 2016 & 2016 & Negado seguimento & Monocrática & Federal & Associação/Confederação/Sindicato & Executivo Federal & Dias Toffoli & Consumidor \\
\hline
\end{tabular}

Fonte: Barros (2018). 
Anexo 2 - Guia de preenchimento da planilha no programa Excel.

\section{Passo 1: Tipo de controle e processo $n^{\circ}$.}

Escrever, na primeira linha da planilha, qual é tipo de controle e o número do processo analisado pelo pesquisador.

Passo 2: Ano ingresso e ano da decisão final

Escrever as datas de ingresso e da data final da decisão.

Passo 3: Decisão final:

( ) Procedente;

( ) Parcialmente procedente;

( ) Negado seguimento;

( ) Improcedente.

Passo 4: Colegiado? Assinalar como foi decidido:

( ) votação unânime;

( ) monocrática ,

( ) majoritária.

Passo 5: Especificar qual é a origem, autor, requerido e o relator (ou relator para o acórdão) do caso.

Passo 6: Especificar o objeto do julgado: Qual é tema tratado no julgado citado?

Para responder essa pergunta, o pesquisador se limitará aos termos apresentados na ementa. Na maioria das vezes, o juiz resume qual é o problema que está em discussão no acórdão. Essa é a questão central do acórdão. Ao escrever isso na tabela, inserir a página da qual se extraiu a questão central.

Passo 7: Especificar o fundamento jurídico indicado no acórdão? Para responder essa pergunta, o pesquisador deverá ler os votos dos ministros e sistematizar cada fundamento indicado e assinalar os seguintes campos:

() lei constitucional. Qual? 


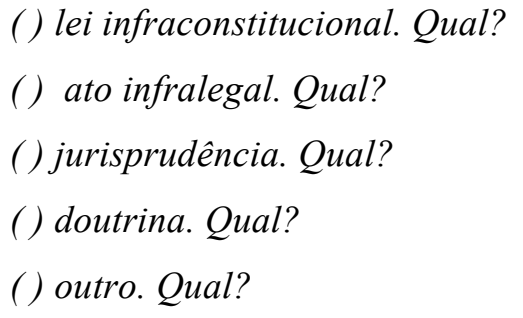

Passo 8: Extrair dos votos a forma de interpretação do tema do central.

() Literal: busca o sentido do textual de um diploma legal, com base nas regras comuns da língua, de modo a se extrair dos sentidos oferecidos pela linguagem ordinária os sentidos imediatos das palavras empregadas pelo legislador.

() Histórico: busca o contexto fático da norma, recorrendo aos métodos da historiografia para retomar o meio em que a norma foi editada, os significados e aspirações daquele periodo passado

() Sistemático: considera em qual sistema se insere esse direito (diálogo das fontes)

() Finalista: busca aos fins sociais e bens comuns do direito

() Sociológico: busca elementos extrajurídicos (políticos, econômicos, etc.), mas que não se relaciona com os fins

Passo 9: Como o ministro se baseia em suas argumentações (quais avaliações são feitas nos votos). Trata-se de uma etapa descritiva e eventuais categorias poderão ser construídas.

Passo 10: Constata-se o uso de argumentos consequencialistas? Se sim:

Qual tipo: () político; () econômico () social

Como o ministro seleciona e avalia as consequências? Descrever.

Constata-se o uso de pareceres técnicos? Se sim, observar-se deferência?

Passo 11: Outra observação que julgar pertinente. 